\title{
A DEMANDA POR SEGURO E O ROUBO DE CARGAS NO TRANSPORTE RODOVIÁRIO BRASILEIRO
}

\section{Augusto hauber Gameiro}

Engenheiro Agrônomo

Orientador: Prof. Dr. JOSÉ VICENTE CAIXETA FILHO

\author{
Dissertação apresentada à Escola Superior de \\ Agricultura "Luiz de Queiroz", Universidade de São \\ Paulo, para obtenção do título de Mestre em \\ Ciências. Área de Concentração: Economia \\ Aplicada. \\ P I R A C I C A B A \\ Estado de São Paulo - Brasil \\ Fevereiro - 1999
}


Dados Internacionais de Catalogação na Publicação (CIP)

DIVISĀO DE BIBLIOTECA E DOCUMENTAÇĀO - Campus “Luiz de Queiroz"/USP

Gameiro, Augusto Hauber

A demanda por seguro e o roubo de cargas no transporte rodoviário brasileiro / Augusto Hauber Gameiro. - - Piracicaba, 1999.

$146 \mathrm{p}$.

Dissertaçāo (mestrado) - - Escola Superior de Agricultura Luiz de Queiroz, 1999.

Bibliografia.

1. Economia de transportes 2. Seguro-roubo 3. Transporte rodoviário de carga I. Título

CDD 388.1 


\section{ERRATA}

- Página 38; $3^{\circ}$ parágrafo: onde se lê "indenizadas", leia-se "indexadas";

- Página 41; título da Tabela 5: onde se lê "de", leia-se "e";

- Página 76; cabeçalho da Tabela 31: onde se lê "Valor", leia-se "Representação";

- Página 113; $4^{\circ}$ parágrafo: onde se lê "retificaram", leia-se "ratificaram";

- Página 115; $7^{\circ}$ parágrafo: onde se lê "FRERCT>100", leia-se "FRERCT<100";

- Página 116; Tabela 43; $4^{\mathrm{a}}$ coluna; $2^{\mathrm{a}}, 3^{\mathrm{a}}$ e $4^{\mathrm{a}}$ linhas: onde se lê " $32,6 \% 44,0 \%$ $56,0 \% "$, leia-se "74,2\% 43,9\% 23,4\%"

- Página 116; $1^{\circ}$ parágrafo: desconsiderar $2^{\mathrm{a}}$ e $3^{\mathrm{a}}$ linhas.

- Página 126; $3^{\circ}$ parágrafo: desconsiderar os valores de I.I. mencionados nesse texto. Considerar os valores ilustrados na Figura 28.

- Página 138; $3^{\circ}$ parágrafo: onde se lê "interessam", leia-se "interessa". 
Dedico

Ao meu Avô,

o contador Germano Hauber (in memorian)

Ao meu Pai,

o administrador de empresas João Luís Prietto Gameiro

Pelo seu exemplo de vida e profissionalismo.

A Deus,

Pela nossa existência. 


\section{AGRADECIMENTOS}

Ao Prof. José Vicente Caixeta Filho um agradecimento especial pela sua orientação sempre dedicada. Mais que isso, meu sincero reconhecimento pelo incentivo e segurança que sempre me proporcionou.

Aos Professores membros da banca, Geraldo S. de Camargo Barros e Newton R. de Castro Júnior, pelas críticas e sugestões valiosas. Agradeço ainda, aos Professores Paulo Millan e Adriano Azevedo Filho, pelas contribuições que deram a esta pesquisa.

Às mais de 200 empresas transportadoras que gentilmente forneceram as informações necessárias para a elaboração deste trabalho.

Às assessorias de segurança de três grandes sindicatos de empresas de transporte de carga no Brasil: SETCESP (São Paulo), SINDICARGA (Rio de Janeiro) e SETCEB (Bahia), pelo fornecimento de dados fundamentais para o estudo.

Ao meu País que, apesar de todas a dificuldades, me proporcionou um excelente curso de Mestrado, bem como recursos financeiros para cursá-lo. Espero poder contribuir em sua busca incansável pelo desenvolvimento econômico e social.

A três grandes colegas que, além de grandes amigas, contribuíram de diferentes maneiras para minha pesquisa: Paula Galvani, Sílvia Helena Miranda e Nancy de Deus Vieira. A esta última, um agradecimento especial pela sua colaboração no que se refere ao conhecimento de Econometria que me transmitiu.

A grandes amigos (as) que tornaram minha vida na bela Piracicaba ainda mais feliz: Fábio, Felipe, Mauricio, Pedro, Valter, Clóvis, Marcelo, Renato, Luciana Cristina, Melissa, Juliana, Ana Carolina, Liliane, Margarete e Stivilane.

À minha futura esposa, Michelle Velleda Borges, por tudo que significa para mim, e por ter sido capaz de suportar os mais de $1.500 \mathrm{~km}$ de distância que nos separou durante meu mestrado.

Com muito amor, à minha querida família que sempre me incentivou: meus pais João Luis e Mara; meus irmãos Gustavo e Paula; nossa Maria Luiza; e minha adorável vó Rosália. 


\section{SUMÁRIO}

Página

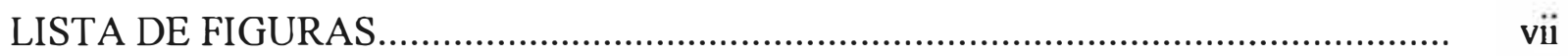

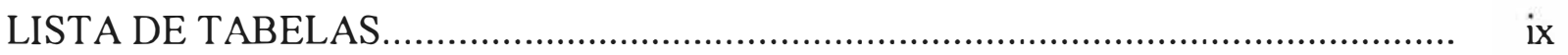

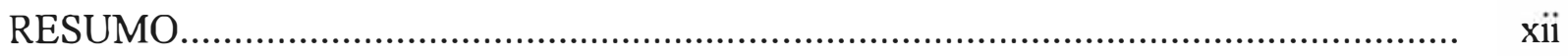

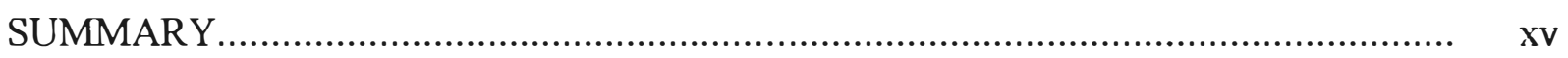

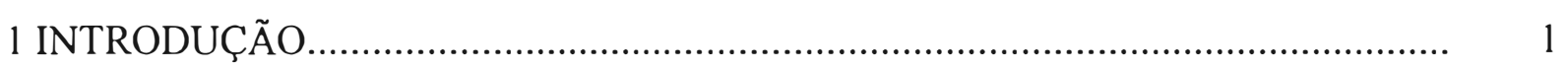

1.1 Objetivos e Justificativa.................................................................................... 1

1.2 Transporte Rodoviário de Carga............................................................................ 3

1.3 Estrutura do Trabalho......................................................................................... 11

2 ROUBO DE CARGAS E SEGURO DE TRANSPORTE .......................................... 12

2.1 Características do Roubo de Cargas........................................................................ 12

2.1.1 Situação no Brasil............................................................................................ 13

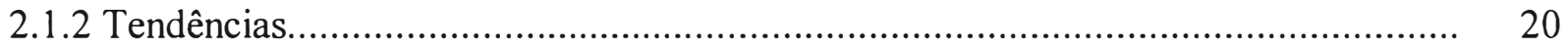

2.2 Carteira de Seguro de Transporte...................................................................... 22

2.2.1 Sub-Ramo Nacional Terrestre ...................................................................... 26

2.2.2 Responsabilidade Civil do Transportador Rodoviário de Carga (RCTR-C)............ 28

2.2.3.Responsabilidade Civil do Transportador Rodoviário por Desaparecimento de

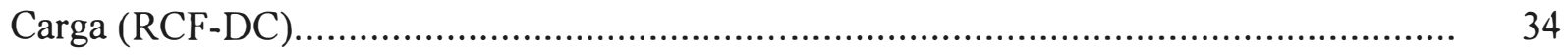

2.3 Mercado Segurador Brasileiro.......................................................................... 37

3 MATERIAL E MÉTODOS.............................................................................. 47

3.1 Descrição das Variáveis................................................................................ 50

3.2 Análise do Comportamento das Empresas de Transporte como Consumidoras de

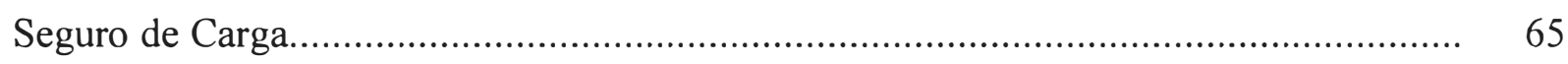

3.2.1 Técnicas de Estatística Descritiva e Não-Paramétrica.............................................. 68

3.2.2 Modelos de Resposta Qualitativa..................................................................... $\quad 70$

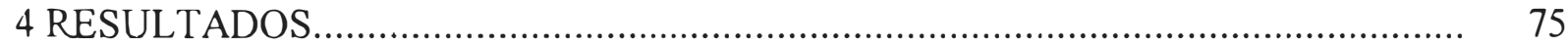

4.1 Características Gerais da Amostra........................................................................ 75 
4.2 Experiência das Empresas com o Roubo de Cargas................................................. 80

4.3 Verificação das Hipóteses................................................................................. 86

4.3.1 Dificuldade de Acesso dos Transportadores ao Serviço de Seguro.......................... 87

4.3.2 Exigências sobre os Transportadores em relação à Compra de Seguro................... 92

4.3.3 Conhecimento dos Transportadores em Relação ao Seguro................................... 102

4.3.4 Interesse dos Transportadores pelo Seguro......................................................... 114

4.4 Modelo de Resposta Qualitativa: Aplicação na Demanda por Seguro de Carga......... 128

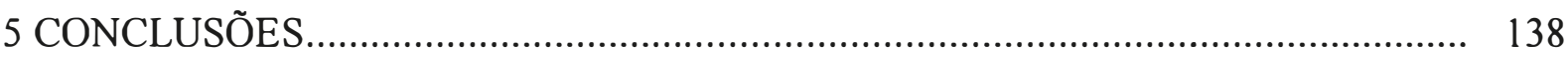

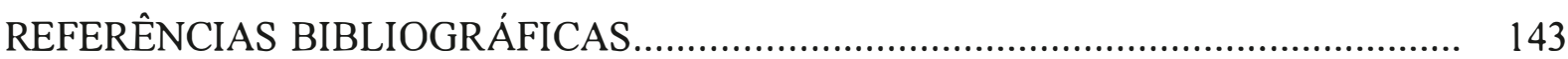

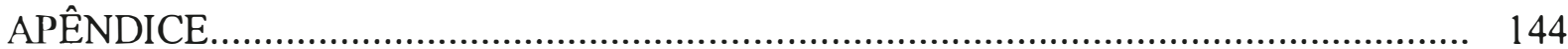




\section{LISTA DE FIGURAS}

Página

1 Participação do volume de carga transportada por modal no Brasil em 1995.. 7

2 Evolução do volume de carga transportada por modal no Brasil entre 1988 e 1995

3 Evolução anual do número de roubos de cargas nos Estados do Rio de Janeiro e São Paulo

4 Evolução anual dos valores de roubos de cargas nos Estados do Rio de Janeiro e São Paulo

5 Horário de ocorrência de roubos de cargas, 1996

6 Resumo do Ramo de Seguros de Transporte. 24

7 Percentual do Prêmio Total, por Ramo, para o ano de 1997. 40

8 Participação das empresas conforme tipo de carga operada, 1996. 78

9 Participação das empresas da amostra conforme tipo de carga operada. 78

10 Participação das empresas da amostra conforme o tamanho de sua frota (TFROTA).

11 Participação das empresas da amostra conforme a idade média de sua frota (IFROTA).

12 Participação das empresas da amostra em função do número de roubos de cargas sofridos pela empresa nos últimos 5 anos (NROUBO).

13 Frequência das empresas - ordenadas conforme o tamanho de sua frota - em função do número de roubos de cargas sofridas nos últimos 5 anos.

14 Distribuições de Probabilidade da Variável ER5.

15 Participação das empresas conforme frequência com que utilizam o seguro RCF-DC (FRERCF).

16 Participação das empresas conforme frequência com que utilizam o seguro RCTR-C (FRERCT). 
17 Matriz Comparativa FRERCT x FRERCF: participação das empresas conforme frequência com que utilizam os seguros RCTR-C e RCF-DC, respectivamente.

18 Participação das empresas conforme as variáveis EXIRCT e EXIRCF (exigência dos embarcadores para o RCTR-C e o RCF-DC, respectivamente)

19 Matriz Comparativa EXIRCT x EXIRCF : participação das empresas segundo exigências que sofrem dos embarcadores para a utilização dos seguros RCTR-C e RCF-DC, respectivamente.

20 Participação das empresas - separadas conforme o seu tamanho - em termos de especialização na administração dos seguros

21 Porcentagem de empresas com especialização de seguros - em função do tamanho de sua frota - segundo dados da amostra e segundo previsão com equação estimada com esses dados

22 Participação das empresas da amostra segundo os atributos "Burocracia" e "Dificuldade", obtidos da variável ADMSEG (impressão sobre a administração dos seguros).

23 Participação das empresas da amostra segundo a impressão que têm sobre o serviço prestado por seu corretor de seguros (SERVCO)

24 Participação das transportadoras da amostra conforme a variável COMPRR. (comportamento do embarcador em relação ao seguro RR)

25 Matriz Comparativa $\$ R C T R C \times \$ R C F D C$ (impressão sobre os preços dos seguros RCTR-C e RCF-DC, respectivamente): participação das empresas conforme resposta apresentada.

26 Distribuição das empresas da amostra segundo a variável NOTCRT (nota atribuída ao seguro RCTR-C)

27 Distribuição das empresas da amostra segundo a variável NOTCRF (nota atribuída ao seguro RCF-DC).

28 Índices de Importância dos diferentes procedimentos de gerência de risco...... 


\section{LISTA DE TABELAS}

Página

1 Estado de conservação das rodovias federais brasileiras em 1997.................. 15

2 Principais cargas roubadas nos estados do Rio de Janeiro, São Paulo e Bahia, em ordem de importância..................................................................... 19

3 Características gerais dos seguros de carga para o Transporte Rodoviário...... 25

4 Participação do Mercado Segurador no Produto Interno Bruto do Brasil....... 38

5 Prêmio Total e participação no total do ramo. para os ramos "Transportes" de "Demais Ramos".............................................................................. 41

6 Sinistralidades I e II para os seguros de transportes e para os de responsabilidade civil de transportadores..................................................... 43

7 Número de empresas e participação desse número no mercado dos seguros mencionados.

8 Índices de concentração das quatro, oito e doze maiores seguradoras, em três anos, para os mercados dos seguros mencionados................................... 46

9 Tamanho da amostra e comparação com a PATR/IBGE.................................. 48

10 Descrição das variáveis da pesquisa............................................................. 51

11 Descrição da variável ESTABEL.......................................................... 52

12 Descrição da variável CLASSE ............................................................... 54

13 Descrição da variável TCARGA............................................................. 54

14 Descrição da variável FUNDAÇ......................................................... 55

15 Descrição da variável TFROTA.......................................................... 56

16 Descrição da variável IFROTA........................................................... 57

17 Descrição da variável FINANC................................................................ 57

18 Descrição da variável NROUBO .............................................................. 58

19 Descrição da variável PROCED............................................................... 59

20 Definição da variável ESPESG ............................................................ 59

21 Definição da variável ADMSEG .............................................................. 60

22 Definição das variáveis NOTRCT e NOTRCF ............................................. 60 


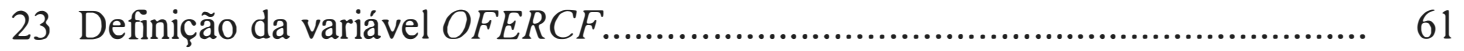

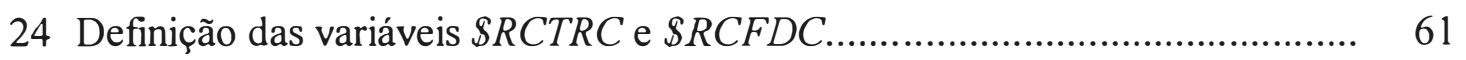

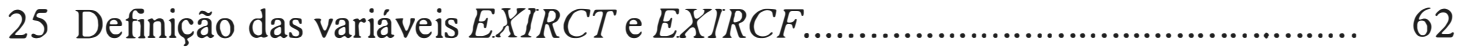

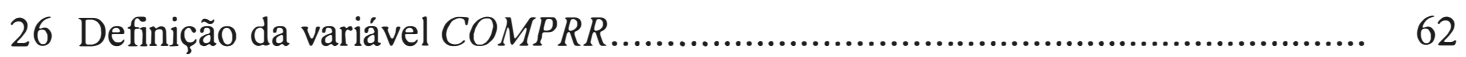

27 Definição das variáveis FRERCT e FRERCF ......................................... 63

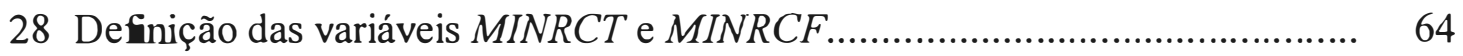

29 Definição da variável SERVCO.......................................................... 64

30 Tamanho da amostra selecionada, número de questionários respondidos e índice de retorno........................................................................ 75

31 Características básicas da amostra .................................................. 76

32 Comparativo da participação das empresa por Unidade da Federação........... 76

33 Média do número de roubos sofridos pelas empresas (NROUBO) ordenadas conforme o tamanho da frota que operam $($ TFROTA $)$............................. 82

34 ER5 das empresas conforme o tipo de carga que operam........................... 85

$35 E R 5$ das empresas conforme a sua localização geográfica........................... 85

36 Participação das empresas, número de empresas (n) e média da variável OFERCF (problemas de oferta do RCF-DC), conforme as variáveis FRERCF (frequência com que utilizam o seguro RCF-DC) e TFROTA (tamanho da frota).

37 Participação das empresas - divididas em pequenas, médias e grandes conforme as exigências que sofrem dos embarcadores para a compra dos seguros RCTR-C e RCF-DC

38 Participação das empresas - divididas segundo o tipo de carga que operam conforme as exigências que sofrem dos embarcadores para a compra dos seguros RCTR-C e RCF-DC.

39 Participação das empresas segundo a variável ADMSEG (impressão sobre a administração dos seguros)

40 Participação das empresas, separadas pelo tamanho de sua frota. segundo a variável ADMSEG (impressão sobre a administração dos seguros). 
41 Participação das empresas segundo as variáveis $A D M S E G$ (impressão sobre a administração dos seguros) e ESPSEG (especialização na administração dos seguros), analisadas de forma conjunta............................................. 109

42 Participação das empresas da amostra conforme as variáveis ADMSEG (impressão sobre a administração dos seguros) e SERVCO (avaliação do serviço prestado pelo corretor), analisadas de forma conjunta.

43 Participação das empresas - agrupadas pela variável FRERCT (frequência com que utilizam o RCTR-C) - conforme algumas variáveis comparativas..... 116

44 Participação das empresas - agrupadas pela variável FRERCF (frequência com que utilizam o seguro RCF-DC) - conforme algumas variáveis comparativas.

45 Médias e Desvio Padrão das variáveis NOTRCT e NOTRCF (notas atribuídas aos seguros RCTR-C e RCF-DC, respectivamente)

46 Procedimentos de gerência de risco considerados, suas siglas e as categorias em que se enquadram.

47 Número de colocações, pontos parciais e Índices de Importância (I.I.) dos procedimentos de gerência de risco

48 Índices de Importância conforme o tamanho das empresas.

49 Equações de demanda por seguros de responsabilidade civil de transportadores rodoviários de carga. Informações da média, coeficiente estimado (em negrito), e teste-t (entre parênteses). 


\title{
A DEMANDA POR SEGURO E O ROUBO DE CARGAS NO TRANSPORTE RODOVIÁRIO BRASILEIRO
}

\author{
Autor: AUGUSTO HAUBER GAMEIRO \\ Orientador: Prof. Dr. JOSÉ VICENTE CAIXETA FILHO
}

\section{RESUMO}

O roubo de cargas tem sido um sério problema no Brasil, principalmente a partir do inicio dos anos 90. O modal de transporte rodoviário, por apresentar grande importância na movimentação de cargas no Pais, é aquele que está tendo maior dificuldade para enfrentar esse tipo de delito.

Este contexto de insegurança vem exigindo uma revisão dos métodos de Gerência de Risco por parte das empresas transportadoras e dos embarcadores (os proprietários das cargas).

O seguro de carga, um tradicional método de Gerência de Risco, vem sendo questionado em relação à sua eficiência e disponibilidade, diante do elevado risco de ocorrência do roubo.

Neste trabalho foram estudados os condicionantes da demanda por seguro de carga por parte das empresas transportadoras, com um enfoque no tratamento do risco de roubo de cargas.

As informações utilizadas foram obtidas diretamente de uma amostra de 200 empresas distribuídas ao longo do território nacional. Especialistas no assunto, tais como técnicos em seguro, gerentes de risco e advogados, também foram entrevistados para enriquecer o estudo.

As análises quantitativas foram conduzidas, basicamente, através de técnicas de Estatística Descritiva. Uma análise econométrica, baseada em modelos de escolha discreta foi desenvolvida, objetivando um maior aprimoramento na interpretação dos dados. 
Os resultados obtidos permitiram concluir que as empresas transportadoras vêm se deparando com alguns entraves em relação à utilização de seguros para o risco de roubo de cargas, em vista do elevado risco desse tipo de evento na atualidade

Consequentemente, outros procedimentos de Gerência de Risco passam a ganhar mais importância e, muitas vezes, são condição sine qua non para a utilização do seguro, assumindo assim, características de bens complementares ao seguro

Apesar disso, constatou-se que o seguro de carga, de uma maneira geral, ainda é considerado o método de Gerência de Risco mais importante no transporte rodoviário de carga. As margens reduzidas da atividade, bem como o elevado valor das cargas transportadas, fazem com que a transferência do risco de perdas e danos através do seguro seja a melhor ou, em muitos casos, a única forma de conviver com esse risco.

A administração dos seguros por parte das empresas transportadoras foi igualmente analisada. Verificou-se a existência de alguns entraves relacionados a esse assunto, tais como a dificuldade com que certas empresas têm na operacionalização desses seguros, principalmente aquelas de menor porte ou menos estruturadas.

Os seguros de carga são relativamente complexos. Essa característica, associada aos problemas advindos de uma maior ocorrência do roubo de cargas, faz com que realmente a manutenção desses seguros seja mais complicada.

A regulamentação dos seguros no Brasil, de certa forma ainda bastante rigida, foi outro ponto abordado na pesquisa. A utilização de contratos com características tipo "padrão", muitas vezes, pode acabar não se adequando às reais necessidades dos segurados. Um exemplo característico são as taxas mínimas para a estipulação dos prêmios do seguro.

Nesse mesmo sentido, um aspecto que deveria ser revisto é a imposição legal sobre a utilização de alguns seguros, mesmo porque os resultados mostraram que muitas dessas imposições não são obedecidas pelas empresas.

Através da utilização de modelos econométricos, analisou-se também os condicionantes da demanda das empresas de transporte pelos seguros de carga. Os resultados da estimação dos modelos foram condizentes com o esperado e com as análises qualitativas, tendo apresentado níveis de significância bastante elevados 
Em linhas geraıs, a localização geográfica das empresas de transporte é uma variável que influencia a demanda por seguro, principalmente o seguro de roubo Empresas localizadas em regiões onde o problema é mais evidente, tal como o Estado de São Paulo, tendem a demandar mais esse tipo de seguro.

O tamanho da frota operada pelas empresas, adotada como indicação da riqueza das empresas, também apresentou uma influência significativa na demanda por seguros. Essa informação permite verificar o "tipo" do bem seguro.

O seguro de responsabilidade dos transportadores (RCTR-C) mostrou-se um bem superior, pois à medida que aumenta a riqueza das empresas, a sua demanda também aumenta. Já o seguro de roubo (RCF-DC) mostrou-se um bem inferior, porém com uma menor significância e um menor coeficiente

O número de roubos sofridos pelas empresas apresentou forte influência sobre a demanda pelo seguro de roubo. As empresas que têm experiência com um elevado número de roubos sofridos apresentam uma maior demanda pelo seguro.

Finalmente, o trabalho procurou não perder de vista a inserção do problema do roubo de cargas em um ambiente macro de profundas mudanças econômicas e estruturais, as quais certamente também acabam influenciando a contratação dos seguros. 
THE DEMAND FOR INSURANCE AND THE CARGO THEFT IN THE

BRAZILIAN HIGHWAY TRANSPORT

\author{
Author: AUGUSTO HAUBER GAMEIRO \\ Adviser: Prof. Dr. JOSÉ VICENTE CAIXETA FILHO
}

\title{
SUMMARY
}

The cargo theft has been a serious problem in Brazil, mainly starting from the beginning of the 90 's. The highway transport modal, due to its great importance in the movement of loads in the country, is the one that is having larger difficulty to face that crime type.

This insecurity context has required a revision of the Risk Management methods by the transportation companies (carriers) and the shippers.

The cargo insurance, a traditional method of Risk Management, is being questioned in relation to its efficiency and readiness, under the high risk of occurrence of the theft.

In this study the demand conditions for cargo insurance by carriers were analyzed focusing in the risk treatment of cargo theft.

The information used were obtained directly from a sample of 200 companies distributed throughout the national territory. Specialists in the subject, such as technicians in insurance, risk managers and lawyers, were also interviewed to enrich the study.

The quantitative analyses were done, basically, through techniques of Descriptive Statistics. An econometric analysis, based on discrete choice models, was developed aiming at an improvement in the data interpretation.

The obtained results allowed to conclude that the carriers are facing some bottlenecks in relation to the use of insurances for the risk of cargo theft, basicaly due to the high risk of that event type at the present time. 
Consequently, other procedures of Risk Management start to get more importance and many times they are considered condition sime qua non for the use of insurance, situation that they assume the characteristics of complementaty goods to the insurance.

Nonetheless, it was verified that the cargo insurance, in general sense, is still considered the most important method of Risk Management in the highway transport of loads. The reduced margins of the activity, as well as the high value of the transported loads, make the transfer of losses and damages risk through the insurance the best of all alternatives or, in many cases, the only way of living with that risk.

The administration of the insurances by the transportation companies was also analyzed. The existence of some difficulties related to that subject was verified, such as the one that some companies mainly those of smaller size or less structured ones, have in handling this kind of insurance.

The cargo insurance are relatively complex. This feature, associated to the problems originated from a larger occurrence of cargo theft, make the maintenance of those insurances more complicated.

The regulation of the insurance in Brazil, in a certain way still quite rigid, was another point approached in this study. The use of contracts with standard characteristics many times may become not appropriate to the real needs of the insurance holders. A typical example is the minimum rates for the stipulation of the insurance premium.

In the same way, an aspect that should be reviewed is the legal imposition about the use of some insurances, once the results showed that many of those impositions are not followed by the companies.

Through the use of econometric models, it was also analyzed the conditions of the demand by the transportation companies for the load insurances. The results of the model were consistent not only to what was expected but also to the qualitative analyses, having presented very high significance levels.

In general sense, the geographical location of the transportation companies is a variable that influences the demand for insurance, mainly the theft insurance. Companies 
located in areas where the problem is more evident, such as the State of São Paulo, tend to have a higher demand for that type of insurance.

The fleet size operated by the companies, adopted as indication of companies wealth, also presented a significant influence in the demand for insurance. That information allows to verify the type of the insurance good.

The insurance of transporters responsibility (RCTR-C) can be considered as a superior good, because as the wealth of companies increases, its demand also increases On the other hand, the robbery insurance (RCF-DC) seemed to be a inferior good, even with a smaller significance level and a smaller coefficient.

The number of theft suffered by the companies presented strong influence on the demand for the theft insurance. The companies that have experience with a high number of suffered thefts present a larger demand for the insurance.

Finally, the study tried not to discard the insertion of the cargo theft problem in a macro environment of deep economical and structural changes, which certainly end up influencing the use of insurances as a whole. 


\section{INTRODUÇÃO}

\subsection{Objetivos e Justificativas}

Segundo a Confederação Nacional do Transporte ${ }^{1}$ (CNT), o setor de transporte rodoviário de carga no Brasil é composto por 12 mil empresas de transporte, 50 mil empresas com transporte de carga própria, empregando 3,5 milhões de pessoas, com um faturamento anual de US\$ 24 bilhões, apresentando uma participação de 59\% na movimentação de carga e dispondo de uma frota nacional composta por 1,5 milhão de caminhões.

Dadas essas dimensões do setor, fica claro que qualquer imperfeição em seu desempenho tem um efeito significativo sobre as demais atividades da economia brasileira.

A ocorrência frequente de desaparecimento de cargas - seja nas estradas ou no meio urbano - vem afetando consideravelmente o desempenho do setor. Para se ter uma idéia, no ano de 1998, foram registrados no Estado de São Paulo 1.334 eventos, totalizando US\$122,46 milhões em cargas roubadas ${ }^{2}$.

Métodos tradicionais de Gerência de Risco na atividade de transporte rodoviário, como a utilização de seguro para carga, estão sendo questionados - em relação à sua eficiência e disponibilidade - por diversos segmentos do setor, incluindo transportadores, embarcadores, corretores de seguro e seguradores.

Além disso, este contexto de insegurança está exigindo uma revisão dos métodos de Gerência de Risco, que vão desde um simples treinamento oferecido ao condutor do veículo de transporte, até a utilização de tecnologias mais avançadas de comunicação via satélite entre o veículo e uma central de controle.

\footnotetext{
'Confederaçāo Nacional do Transporte. In homepage: www.cnt.org.br (1998).

2 Assessoria de Segurança do Sindicato das Empresas de Transporte de Carga de São Paulo e Região (SETCESP).
} 
Obviamente que qualquer tomada de decisão na escolha entre os diferentes métodos de Gerência de Risco por parte dos transportadores exige um conhecimento adequado dessas ferramentas, bem como condições financeiras capazes de fazer frente aos custos necessários à sua adoção e operacionalização. Tais exigências podem tornarse pontos de estrangulamento para algumas empresas do setor, principalmente às de pequeno e médio porte.

Neste trabalho dar-se-á ênfase à análise do comportamento da empresa transportadora como consumidora de seguros de carga. A análise ora proposta buscará na Ciência Econômica a base para o seu desenvolvimento.

As informações necessárias para a elaboração desta pesquisa serão obtidas junto aos transportadores. Especialistas no assunto, tais como técnicos em seguro, gerentes de risco de empresas transportadoras e advogados, também serão entrevistados para enriquecer o estudo.

Diante dessas observações, o presente trabalho apresenta como objetivo principal a análise dos motivos que levam, ou não, os transportadores à utilização de seguros de carga como forma de gerência de risco. Portanto, ênfase maior será dada aos seguros de responsabilidade civil de transportadores. O tratamento ao risco de roubo de cargas merecerá atenção especial nesse contexto, em vista da importância do problema na atualidade.

Sob esse objetivo, as seguintes hipóteses são formuladas:

1. Há empecilhos ao acesso dos transportadores ao seguro de carga. Caso essa hipótese não venha a ser refutada, serão pesquisados quais os principais motivos que levam a tal, e que tipo de empresa estaria se defrontando com tal realidade.

2. Há exigências - sejam legais. ou por parte dos embarcadores - sobre os transportadores, para a compra de seguro de carga. Em não se refutando essa 
hipótese, é necessário que se verifique quais são essas exigências, a quem são impostas, e qual o fundamento dessas imposições.

3. Há um desconhecimento por parte dos tomadores de decisão - os transportadores - em relação ao funcionamento do seguro de carga. Existindo esse desconhecimento, é importante que se procure identificar as características das empresas onde isso ocorre.

4. Há desinteresse em relação à utilização de seguro de carga pelos transportadores. Caso essa hipótese não possa ser refutada, há que se caracterizar o tipo de empresa e os motivos que podem levar a esse comportamento.

Procurar-se-á ainda, durante o desenvolvimento dessas análises, o entendimento de sua inserção em um ambiente macroeconômico que passa por sensíveis mudanças, seja no setor de transporte propriamente dito, como no mercado segurador e, ma1s genericamente, nas relações sócio-econômicas do País como um todo.

\subsection{Transporte Rodoviário de Carga}

Há no Brasil, uma carência de informaçōes básicas sobre o setor de transporte rodoviário de carga (TRC).

O Instituto Brasileiro de Geografia e Estatística (IBGE) é uma das poucas instituições que levantam dados sistemáticos do setor, através da sua Pesquisa Anual do Transporte Rodoviário (PATR).

A partir de 1988, uma editora iniciou um importante trabalho de levantamento de dados financeiros das empresas de transporte do País ${ }^{3}$.

\footnotetext{
${ }^{3}$ Publicaçāo Anual "As Maiores do Transporte”, da Editora Transporte Moderno, Sāo Paulo SP.
} 
Além da carência de informações básicas, praticamente não há estudos analíticos que examinem as principais relações e condicionantes do comportamento do setor, conforme prega Castro (1988). Esse autor, inclusive, é um dos poucos que se dedicaram a esses estudos.

A escassez de referências bibliográficas é um aspecto relevante e que dificulta a elaboração de estudos específicos sobre o tema "transporte rodoviário de carga". Eis, portanto, a primeira grande dificuldade encontrada nesta pesquisa.

A necessidade de maiores conhecimentos sobre o TRC ainda é reforçada por dois aspectos citados por Castro (1988): a diversidade de tipos de agentes econômicos (transportadores autônomos, de carga própria, etc.), e também pela dinâmica da sua evolução.

Não se pretende aqui tratar minuciosamente as características do TRC; contudo, algumas informações são necessárias para melhor focalizar o problema em estudo.

O primeiro ponto que deve ser considerado para pesquisas em transportes é a definição do "produto de transporte". Segundo Castro (1988), as dimensões usualmente ditas mais importantes para a definição desse produto são:

- requisitos quanto ao equipamento de transporte, impostos pelo tipo de produto ou pelo serviço prestado;

- tamanho do lote de carga (densidade);

- distância entre origem e destino; e

- volume e distribuição geográfica da demanda na malha de transporte.

Consequentemente, esses aspectos também são determinantes do "produto de seguro de carga" a ser utilizado para a cobertura da mesma, principalmente, em relação à taxa de prêmio cobrada pelas seguradoras.

Para o estudo da demanda por seguro, serıa ideal a exata delimitação das empresas segundo cada um daqueles aspectos. Devido à carência de dados, isso não ocorre, fazendo com que a pesquisa acabe perdendo precisão. Mesmo assim, procura-se - dentro do possível - captar as informações necessárias. 
Voltando-se aos condicionantes do produto de transporte estudado por Castro (1988), uma das inferências mais importantes é a de que a densidade do transporte e a sua distribuição geográfica criam uma grande diversidade de vantagens comparativas entre as empresas:

“...as pequenas empresas, que se concentram no transporte de carga inteira, com investimentos preponderantemente em veículos, (...) atuariam com vantagem em mercados com baixa densidade de carga, onde, devido às reduzidas barreiras à entrada e à maior mobilidade dos fatores, prevaleceria um regime de mercado competitivo" (pág. 67).

As empresas de tamanho médio, por sua vez, se concentrariam em linhas específicas, preponderantemente regionais.

Finalmente, para as grandes empresas, Castro identifica aquelas com ampla rede de pontos inter-regionais e com elevados investimentos fixos. Tais empresas atuariam em mercados de maior densidade, caracterizados por regime de monopólio ou oligopólio, sendo esse regime, dependente das condiçōes de demanda.

Em relação à estrutura de custo, Castro observou um alto valor para a razão custo operacional/receita operacional que, segundo ele, estaria em torno de $91 \%$, e passando para 94-95\% quando considerados os impostos sobre a atividade. Conclui então, o autor:

"Este fato, associado a um mercado competitivo, faz com que as empresas operem com margens de lucro bastante vulneráveis às flutuaçōes de demanda e de custos - pequenas variaçōes nestes podem levar a perdas consideráveis" (pág. 68).

Essa constatação é de suma importância para o presente trabalho, que procurará abordar a reação das empresas de transporte frente ao risco de perda de cargas. 
Outro ponto investigado por Castro (1988) foi a estrutura do mercado de transporte rodoviário de carga. A maior preocupação do autor era entender como que firmas de tamanhos diferentes poderiam coexistir no mercado.

A conclusão do autor foi a de que na faixa das grandes empresas havia uma estrutura com tendência oligopolística, enquanto na faixa das pequenas empresas, a competição pura era a mais adequada para explicar o mercado. As primeiras tendem a atuar em rotas com tráfego mais denso e com cobertura geográfica mais ampla. As segundas explorariam nichos do mercado de rotas com tráfego menos denso, ou serviços mais especializados.

Eis outra importante contribuição do estudo de Castro (1988) para o presente estudo: o "tamanho" da empresa - que se refletiria na sua forma de atuação - deve ser uma variável fundamental para o estudo de seu comportamento como consumidora de seguro de carga.

Além dessas características intrínsecas do setor, é importante também o entendimento de sua inserção no ambiente econômico do País.

A importância do modal rodoviário para o desenvolvimento do Brasil, bem como o motivo que fez com que a sociedade brasileira o privilegiasse, pode ser brevemente exposto pelas palavras de Uelze (1977):

"A amplidão continental do Brasil foi unida pelas iniciativas individuais do transporte rodoviário, que apenas solicitavam pontes para atravessar os rios, pois os caminhões se incumbiriam de transformar as picadas em estradas" (Prefácio).

Essa importância do modal pode ser verificada na Figura 1. A sua participação corresponde a praticamente $60 \%$ do volume de carga transportada. 


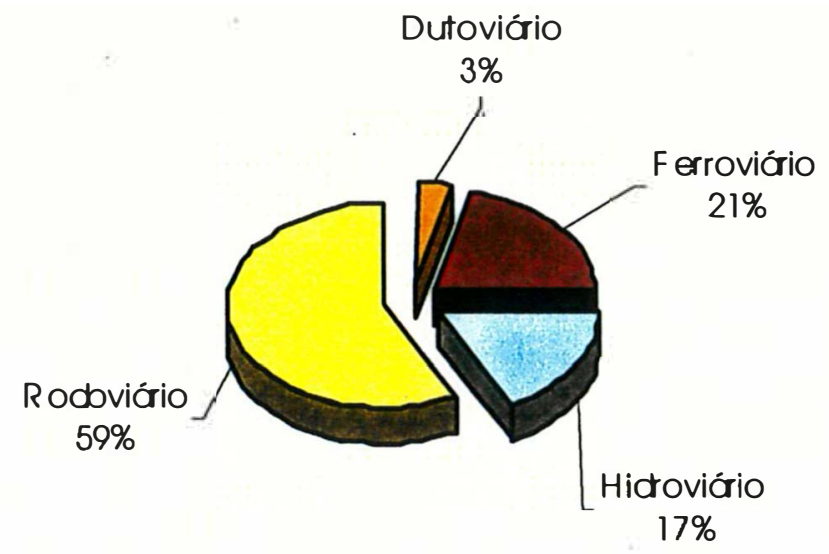

Figura 1. Participação do volume de carga transportada por modal no Brasil em $1995^{4}$. (Fonte: Anuário Estatístico dos Transportes, 1996 - GEIPOT. In homepage: www.cnt.org.br).

Além disso, esse predomínio não sofreu mudanças sensíveis ao longo dos últimos anos, como mostra a Figura 2.

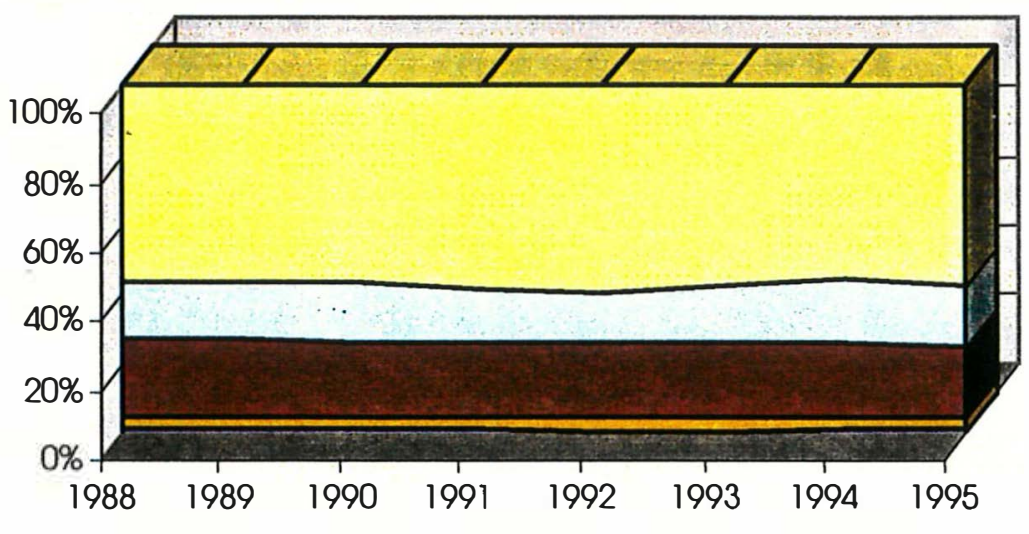

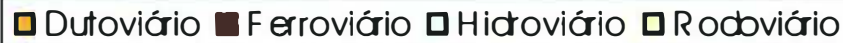

Figura 2. Evolução do volume de carga transportada por modal no Brasil entre $1988 \mathrm{e}$ 1995 (Fonte: Anuário Estatístico dos Transportes, 1996 - GEIPOT. In homepage: www.cnt.org.br).

\footnotetext{
${ }^{4} \mathrm{O}$ modal aéreo apresenta uma participação inferior a $1 \%$ na movimentação de cargas no ano analisado e, por esse motivo, foi excluído da figura.
} 
Uma análise minuciosa dos motivos que levaram a essa predominância do modal rodoviário é apresentada por Galvão (1996). Em síntese, esse autor defende que o transporte rodoviário se sobressaiu sobre os demais, simplesmente pelo fato de que esses últimos foram incapazes de atender às aspirações nacionais.

Para o presente propósito, não se faz necessário maior detalhamento dessas questões. O que deve ficar claro é que essa predominância surge como uma primeira explicação para o fato das numerosas ocorrências de roubos de cargas no modal se tomarem um sério problema na atual conjuntura, e que teve consequências negativas sobre o serviço de seguro, dando início a uma grande discussão que motivou a elaboração desta pesquisa. Basicamente, o modal rodoviário vem sendo o mais acometido por esta problemática por ser o mais exposto à mesma.

A partir do início da década de 90, o Brasil - e outros países da América Latina começou a passar por sensíveis transformações estruturais e de política econômica. No primeiro caso, citam-se as privatizações de empresas estatais e as concessões de estruturas e serviços públicos, tais como malhas ferroviárias, terminais portuários, rodovias, etc. A principal transformação econômica foi uma maior abertura da economia nacional ao comércio mundial que, aliada a outras medidas de política econômica, possibilitou ao. País o controle do processo inflacionário, um dos grandes entraves ao seu desenvolvimento.

A diminuição brusca da inflação refletiu significativamente no desempenho dos setores da economia brasileira, inclusive no mercado segurador e no serviço de transporte rodoviário de carga, nos quais a busca por competitividade passou a ser uma questão de sobrevivência para as empresas.

Além dessas tendências conjunturais, o Governo Federal lançou, em agosto de 1996, o programa "Brasil em Ação", visando promover o desenvolvimento sustentável do País. Ao todo são 42 empreendimentos nas áreas de infra-estrutura e desenvolvimento social, que visam atrair investimentos privados e diminuir as desigualdades regionais e sociais. Do valor total estimado para investimento, $\mathrm{R} \$ 90,3$ 
bilhões, aproximadamente $9 \%$ deverão ser destinados para o setor de transportes, em todas as suas modalidades. No ano de 1997 investiu-se R\$ 31 bilhões, mais de 4\% do PIB. Para 1998 programa-se um investimento de $\mathrm{R} \$ 31,7$ bilhões 5 .

Ainda que essas medidas sejam fundamentais ao desenvolvimento do País, as transformações na regulamentação do setor de transporte - que deveriam acompanhá-las - estão ocorrendo em um ritmo mais lento.

A Lei n. ${ }^{\circ}$ 9.611, de 19 de fevereiro de 1998 (Lei do Operador de Transporte Muldimodal de Carga) - ainda não regulamentada ${ }^{6}$ - deverá estimular os agentes transportadores a mudarem sua forma de atuação, passando a operar em mais de um modal.

O principal aspecto da Lei - denominada Lei do OTM - refere-se ao seu Artigo $2^{\circ}$, que define "Transporte Multimodal de Cargas" como sendo aquele que, "...regido por um único contrato, utiliza duas ou mais modalidades de transporte, desde a origem até o destino, e é executado sob a responsabilidade única de um Operador de Transporte Multimodal".

Não apenas essa Lei, como também toda a reformulação estrutural e econômica já mencionada, deverá fazer com que os outros modais ganhem importância relativa. Todavia, o modal rodoviário continuará sendo o principal elo de ligação entre os outros modais. Além disso, tal reestruturação implicará um maior envolvimento e dependência entre estruturas e etapas na operação de transporte, sendo que a consequência de um sinistro em uma dessas etapas deverá ter efeitos ainda mais danosos ao sistema como um todo.

\footnotetext{
`. Ministério do Planejamento do Governo Federal. In homepage: www.mpo.gov.br (1998).

${ }^{\natural}$ Apesar de sua publicaçāo, a Lei do OTM ainda nāo foi regulamentada, sendo que o principal entrave está relacionado à forma de tributaçāo sobre a atividade.
} 
Especificamente em relação ao seguro de transporte, a Lei do OTM naturalmente exigirá uma revisão na regulamentação dos contratos $^{7}$, bem como deverá alterar os volumes de prêmios relativos entre as diferentes modalidades de transporte. Em outras palavras, as carteiras que contemplam o transporte multimodal deverão aumentar em detrimento daquelas específicas para um determinado modal.

Como pode ser percebido, a idéia de "competição entre modais", que hoje é considerada ultrapassada, passa para uma concepção de "multimodalidade", na qual há uma integração entre os modais.

Na realidade, a idéia de "multimodalidade" também já vem sendo considerada obsoleta, visto contemplar apenas a atividade de transporte. A concepção mais adequada para o processo atualmente, é a de "Logística", mais especificamente, a "Logística Empresarial",

Nas palavras de Ballou (1993):

“A Logística Empresarial estuda como a administração pode prover melhor nível de rentabilidade nos serviços de distribuição aos clientes e consumidores, através de planejamento, organização e controle efetivos para as atividades de movimentação e armazenagem que visam facilitar o fluxo de produtos" (pág. 17).

Percebe-se, portanto, que a atividade de transporte vem tomando dimensões sensivelmente maiores, passando a contemplar vários outros serviços, além da movimentação de cargas. Essa mudança de paradigma, em consequência, clama por revisões nos serviços relacionados diretamente à atividade de transporte, dentre eles, os seguros de carga.

\footnotetext{
${ }^{7} \mathrm{Na}$ realidade já existe um seguro de carga específico para transportadores operando na intermodalidade (Seguro de Responsabilidade Civil do Transportador Intermodal - Carga: RCTI-C); mesmo assim, é provável que o mesmo tenha que sofrer alguma reformulação para atender à nova regulamentação dos transportes.

${ }^{8} \mathrm{O}$ termo "Logística Empresarial" é utilizado por tratar a logística do ponto de vista da administraçāo das empresas.
} 
Assim sendo, torna-se evidente que a atividade de transporte rodoviário de carga, a ser estudada neste trabalho, encontra-se inserida em um ambiente que passa por sensível transformação, ou seja, muito mais que o problema de roubo de cargas que vem sendo considerado bastante sério, o setor deverá enfrentar - e se adequar - a todas essas mudanças e desafios.

\subsection{Estrutura do Trabalho}

O presente trabalho é composto de cinco capítulos.

Neste primeiro capítulo foi apresentada uma introdução à pesquisa a ser desenvolvida. Nele são expostos os motivos, objetivos e importância do tema escolhido.

No capítulo segundo são abordadas informações relevantes sobre o roubo de cargas no País e sobre o serviço de seguro de transporte, mais precisamente, o seguro de carga. Neste capítulo são apresentados os tipos de seguros existentes e o seu objetivo. Aspectos do mercado segurador brasileiro também são incluídos no capítulo.

O terceiro capítulo trata dos materiais e métodos utilizados na pesquisa. $\mathrm{O}$ Capítulo 4, por sua vez, diz respeito aos resultados obtidos com a aplicação da metodologia mencionada.

Finalmente, o último capítulo conclui a pesquisa, trazendo algumas recomendações de caráter geral. 


\section{ROUBO DE CARGAS E SEGURO DE TRANSPORTE}

\subsection{Características do Roubo de Cargas}

Apesar do termo "roubo" ser utilizado genericamente para mencionar a posse indevida de um bem de outrem, a sua distinção com "furto" deve ser considerada.

"Furto", segundo o Código Penal Brasileiro (Gama, 1923), significa: "Subtrair, para si, ou para outrem, coisa alheia, móvel, contra a vontade de seu dono" (Art. 330). Já "Roubo", segundo a mesma legislação, é definido como: "Subtrair, para si, ou para outrem, coisa alheia, móvel, fazendo violência à pessoa ou empregando força contra a coisa "(Art. 384).

Ainda que essa diferenciação seja conhecida, várias vezes o termo "roubo" acaba sendo utilizado para mencionar igualmente os casos de furto ${ }^{9}$.

O roubo e o furto são considerados parte do "crime". Esse nada mais é do que o ato de infringir aspectos legais, o que sugere a imposição de uma pena ou castigo. No Código Penal Brasileiro, "crime” é “...violação imputável e culposa da lei penal” (Art. 7).

Voltando-se para a atividade de transporte, a legislação brasileira pressupõe a culpa do transportador para danos que venham a ocorrer com a carga que lhe é designada para o transporte. Cabe a ele, portanto, empenhar-se em provar o contrário quando algum imprevisto ocorre com a mesma.

Para a análise em questão, é considerado "roubo de carga" a situação em que indivíduos tomam posse ilegalmente de parte ou da totalidade da carga de um veículo transportador, podendo ocorrer, no último caso, o desaparecimento ou não do veículo concomitantemente com a mercadoria roubada, caso em que se utiliza a denominação "desvio de carga".

\footnotetext{
${ }^{9}$ A partir deste momento, o termo "roubo de carga" será genericamente utilizado para mencionar os casos de roubo propriamente dito, furto ou desvio de carga. Esta simplificação é utilizada simplesmente para facilitar a comunicação. Portanto, não deve causar conflitos conceituais.
} 
Pode-se ainda expandir o conceito de "roubo de carga" para ocasiões em que a carga seja tomada indevidamente quando depositada em armazéns diretamente ligados à atividade de transporte, no momento de seu manuseio por ocasião de seu embarque ou desembarque, ou até mesmo quando é indevidamente apropriada pelo motorista do veículo transportador.

No mercado Inglês - considerado referência do mercado segurador mundial - o termo equivalente a "roubo de carga", e que engloba os casos citados anteriormente, é Theft, Pilferage \& Non-Delivery, ou simplesmente TP\&ND. No idioma Espanhol, a expressão correspondente é Robo, Ratería y Falta de Entrega. Essas expressões resumem os eventos de roubo e furto, que acabam resultando em uma falta de entrega da mercadoria.

O resultado imediato de um evento dessa natureza é um desequilíbrio econômico, onde as perdas recaem, de maneira diferenciada, sobre transportadores, embarcadores e seguradores, conforme o caso.

O primeiro passo para o entendimento do roubo de carga passa pelo conhecimento de características básicas a respeito de sua ocorrência.

\subsubsection{Situação no Brasil}

A generalização do roubo de carga no Brasil parece ter se iniciado por volta do ano de 1980. No início, o maior problema era a apropriação indébita, ou seja, o próprio condutor do veículo, portando documentação falsa, desaparecia com a carga. Esse tipo de acontecimento diminuiu com a melhor seleção dos motoristas, bem como com a criação dos cadastros eletrônicos que informam nomes de motoristas idôneos, características dos veículos roubados e nomes de assaltantes (Indenizações consumiram..., 1995).

Atualmente, o que se verifica é a abordagem do veículo através de indivíduos fortemente armados, que desviam o mesmo com toda a carga, ocorrendo ou não o 
sequestro do condutor, o qual, em algumas ocasiões, sofre agressões corporais ou até mesmo é assassinado pelos assaltantes.

Ao que tudo indica, o destino das mercadorias roubadas é o mercado informal ou mesmo o formal. Quando destinadas a esse último, são necessárias falsificações dos documentos fiscais pertinentes, para que ocorra a "legalização" da mercadoria.

Outro destino bastante comum são as favelas, principalmente as do Rio de Janeiro, nas quais ocorre um "serviço" de assistência social prestado à comunidade pelos traficantes de entorpecentes nelas residentes. Esses distribuem as mercadorias roubadas às pessoas em troca de sua "proteção" (Indenizações consumiram..., 1995).

A falta de segurança como um todo tem sido considerada o principal ponto do problema em questão. É sabido que a segurança é um dever do Estado. Contudo, a escassez de recursos públicos faz com que esse e outros deveres sejam relegados a um segundo plano. Ao que parece, ainda que transportadores, embarcadores e seguradoras empenhem-se num melhor tratamento do problema, o mesmo continuará persistindo em níveis acima dos admitidos caso não ocorra uma ação mais efetiva dos órgãos públicos.

O combate ao roubo de carga por parte das autoridades ainda apresenta um agravante devido à característica de mobilidade desse tipo de crime. As quadrilhas atuam em vários estados brasileiros, o que acaba gerando impedimentos legais para as investigações de promotores e policiais em áreas fora de sua jurisdição (Asfalto à mão armada..., 1995).

A estrutura das polícias rodoviárias, sejam elas estaduais ou federais, também é outro complicador da situação. Para se ter uma idéia, de acordo com um superintendente da Polícia Rodoviária Federal (PRF):

“...no Estado de São Paulo, a Polícia Rodoviária Federal necessitaria de um número de policiais três vezes maior do que o atual, para que a instituição conseguisse patrulhar adequadamente os $1.100 \mathrm{~km}$ de rodovias federais no Estado. Além disso, a PRF em São Paulo ficou 20 anos sem renovar seu efetivo, sendo que em 
1995 a renovação ocorreu, não havendo contudo, incremento no número de patrulheiros" (Asfalto à mão armada..., 1995).

Para o entendimento do seguro no transporte rodoviário de carga, as condições das rodovias apresentam importância significativa, influenciando sobremaneira na probabilidade de ocorrência de sinistros.

As condições das estradas de rodagem do Brasil não apresentam segurança adequada no que se refere à existência de telefones, iluminação e patrulhamento policial, além de, muitas vezes, apresentarem uma estrutura física em estado deteriorado.

A Confederação Nacional do Transporte (CNT) elabora uma pesquisa anual no âmbito federal, que ilustra esse fato. A pesquisa abrangeu $70 \%$ das rodovias federais, as quais totalizam aproximadamente $52.000 \mathrm{~km}$. A Tabela 1 ilustra dados daquela pesquisa.

Tabela 1. Estado de conservação das rodovias federais brasileiras em 1997.

\begin{tabular}{cccc}
\hline & $\begin{array}{c}\text { Conservação } \\
\text { Geral }\end{array}$ & $\begin{array}{c}\text { Conservação da } \\
\text { Sinalização }\end{array}$ & $\begin{array}{c}\text { Conservação do } \\
\text { Pavimento }\end{array}$ \\
Estado & $(\%)$ & $(\%)$ & $(\%)$ \\
\hline Péssimo & 0,7 & 12,7 & 3,4 \\
Ruim & 2,2 & 29,9 & 19,1 \\
Regular & 89,4 & 33,6 & 62,8 \\
Bom & 7,2 & 15,6 & 5,0 \\
Ótimo & 0,5 & 8,2 & 9,7 \\
\hline
\end{tabular}

Fonte: Confederação Nacional do Transporte (CNT). In homepage: www.cnt.org.br (1998).

Embora os dados da tabela não sugiram explicitamente um elevado grau de deterioração, quando algumas vias são consideradas isoladamente essa característica fica mais evidente.

Nos casos de roubo de carga, a relação que pode existir entre esse tipo de evento e o estado das vias de rodagem diz respeito, por exemplo, aos casos em que os condutores optam por desvios dos trajetos pré-determinados, com o intuito de evitar o 
trânsito em condições precárias. Geralmente esses desvios são caracterizados por vias menos movimentadas e, consequentemente, menos estruturadas, podendo estabelecer um cenário mais propício ao roubo de carga.

Sobre a recuperação das cargas roubadas por parte da polícia, acredita-se que em torno de $10 \%$ sejam recuperadas ${ }^{10}$, percentagem esta considerada bastante baixa.

Existem no mercado brasileiro empresas especializadas em gerência de risco e recuperação de cargas roubadas, que dispõem de estrutura adequada para fornecer aos clientes uma melhor segurança na atividade de transporte, e que têm conseguido resultados positivos na recuperação de cargas roubadas. Alguns exemplos são os cadastros eletrônicos de condutores idôneos, os sistemas de averbação eletrônica, os sistemas de rastreamento por satélite, entre outros.

$\mathrm{Na}$ realidade, o que parece estar faltando para uma melhor resolução do problema é um projeto amplo de coordenação das ações dos indivíduos em relação ao problema. Algumas iniciativas já foram desenvolvidas, mas sem grandes resultados.

A falta de levantamento de dados estatísticos é um dos principais entraves encontrado no tratamento do problema de roubo de cargas, não só no Brasil, como também em outros países, inclusive nos Estados Unidos (Cottril, 1996; Mooney, 1994).

O Sindicato das Empresas de Transporte de Cargas do Estado de São Paulo (SETCESP), o Sindicato das Empresas de Transporte de Cargas do Estado do Rio de Janeiro (SINDICARGA) e o Sindicato das Empresas de Transporte de Cargas do Estado da Bahia (SETCEB), provavelmente por estarem nas regiões mais acometidas por esse tipo de evento, são exemplos de instituições que apresentam um trabalho efetivo não só de levantamento de dados, como também de assessoria a seus associados em relação ao problema.

Para se ter uma idéia do montante envolvido no roubo de cargas, as Figuras 3 e 4 ilustram a evolução anual dos eventos nos Estados do Rio de Janeiro e São Paulo.

${ }^{10}$ Assessoria de Segurança do SETCESP. Comunicação pessoal, 1997. 


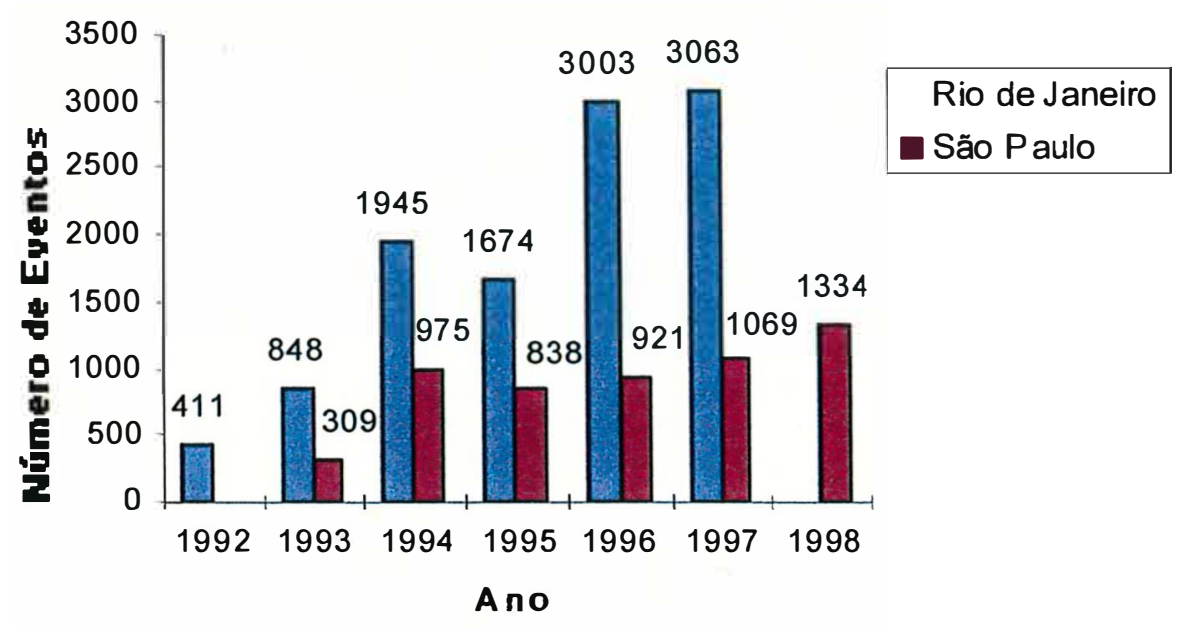

Figura 3. Evolução anual do número de roubos de cargas nos Estados do Rio de Janeiro e São Paulo (Fonte: Assessorias de Segurança do SINDICARGA e SETCESP).

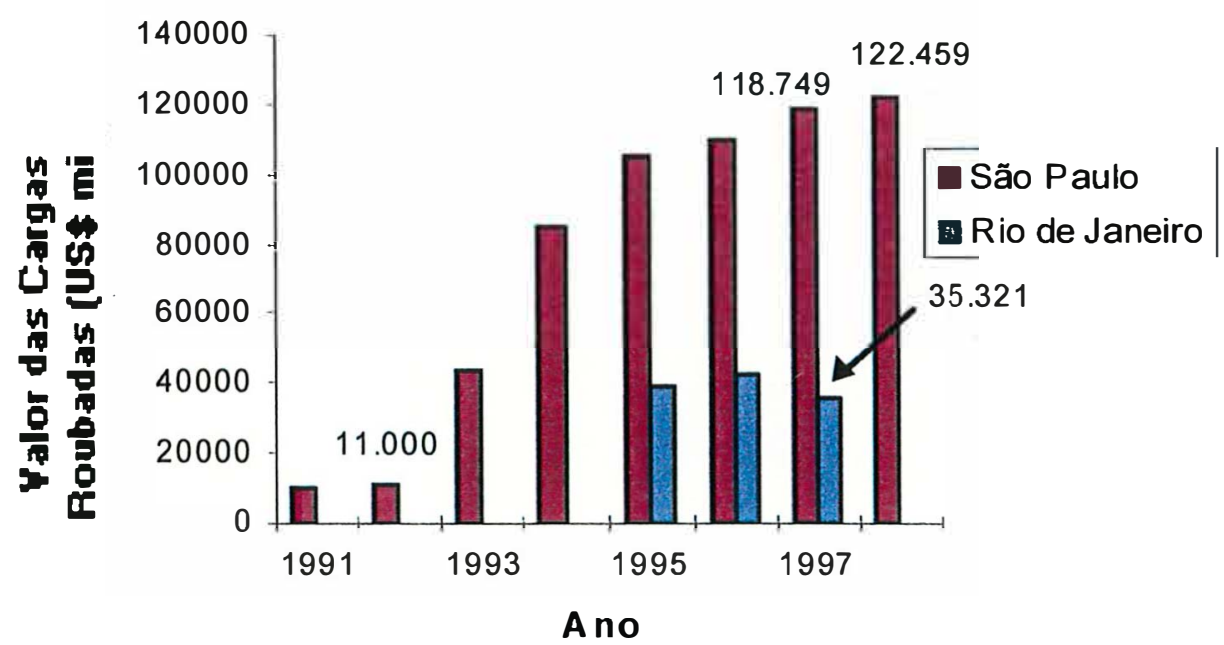

Figura 4. Evolução anual dos valores de roubos de cargas nos Estados do Rio de Janeiro e São Paulo (Fonte: Assessorias de Segurança do SINDICARGA e SETCESP). 
Embora a série de dados não seja suficientemente longa, percebe-se que há uma certa tendência de aumento, tanto no número de eventos, como no valor das cargas roubadas. Para o Estado de São Paulo, o aumento nos valores é sensivelmente maior que o aumento no número de eventos, o que permite inferir que estaria ocorrendo uma maior seleção por cargas de maior valor agregado por parte dos assaltantes.

Comparando-se a evolução dos eventos entre os dois estados, nota-se uma certa distinção no perfil dos roubos. A frequência dos eventos no Rio de Janeiro é maior que em São Paulo, ocorrendo, entretanto, uma inversão em relação aos valores envolvidos. Isso ocorre devido ao fato dos roubos de cargas no Rio de Janeiro serem, muitas vezes, de pequena monta, o que caracterizaria um assalto oportunista. Em São Paulo, por sua vez, o roubo de cargas apresenta-se mais seletivo, o que sugere ser um roubo mais "profissionalizado", mais organizado.

No Estado da Bahia, o terceiro no ranking de roubos de cargas no Brasil, o número de ocorrências é sensivelmente menor que nos Estados do Rio de Janeiro e São Paulo, o que ressalta a gravidade do problema para esses últimos. Conforme a Assessoria de Segurança do SETCEB, nos anos de 1995, 1996 e 1997 foram registradas, respectivamente, 44, 28 e 79 ocorrências no Estado.

Ao longo do País, os assaltos não ocorrem somente nas rodovias, mas também nas ruas de grandes cidades e, ultimamente, até mesmo nos depósitos das indústrias, antes da carga ser entregue para o transporte. No Estado de São Paulo, no ano de 1997, $47 \%$ das ocorrências foram verificadas na própria capital paulista. No Rio de Janeiro, em 1996, os subúrbios da Central, os subúrbios da Leopoldina e a Baixada Fluminense, foram responsáveis por $43 \%$ das ocorrências. O local do delito indica que a preocupação não deve ser apenas das polícias rodoviárias, mas também daquelas atuantes nas zonas urbanas.

Os dados de ocorrências também indicam a preferência pelo roubo de determinadas mercadorias. A Tabela 2 traz as principais cargas roubadas nos últimos anos, nos três principais estados acometidos pela problemática. 
Tabela 2. Principais cargas roubadas nos estados do Rio de Janeiro, São Paulo e Bahia, em ordem de importância.

\begin{tabular}{cccc}
\hline Posição & Rio de Janeiro $^{\mathrm{T}}$ & São Paulo $^{2}$ & Bahia $^{3}$ \\
\hline $1^{\text {a }}$ & Cigarros & Têxteis & Cigarros \\
$2^{\mathrm{a}}$ & Diversas/Fracionada & Diversas/Fracionada & Prod. Químicos \\
$3^{\text {a }}$ & Alimentos & Alimentos & Leite em Pó \\
$4^{\text {a }}$ & Eletro/eletrônicos & Eletro/eletrônicos & Calçados \\
$5^{\text {a }}$ & Medicamentos & Prod. Higiene/Limpeza & Alimentos
\end{tabular}

Fonte: Assessorias de Segurança do SINDICARGA, SETCESP e SETCEB.

${ }^{1}$ Período de 01/01/96 a 03/08/98; ${ }^{2}$ Período de 1997; $\mathrm{e}^{3}$ Período de 1996.

Percebe-se, portanto, uma clara procura por produtos de alto valor agregado e de fácil distribuição no comércio.

Outra informação relevante diz respeito às estatísticas sobre o horário de ocorrência dos roubos. A Figura 5 ilustra essas estatísticas.

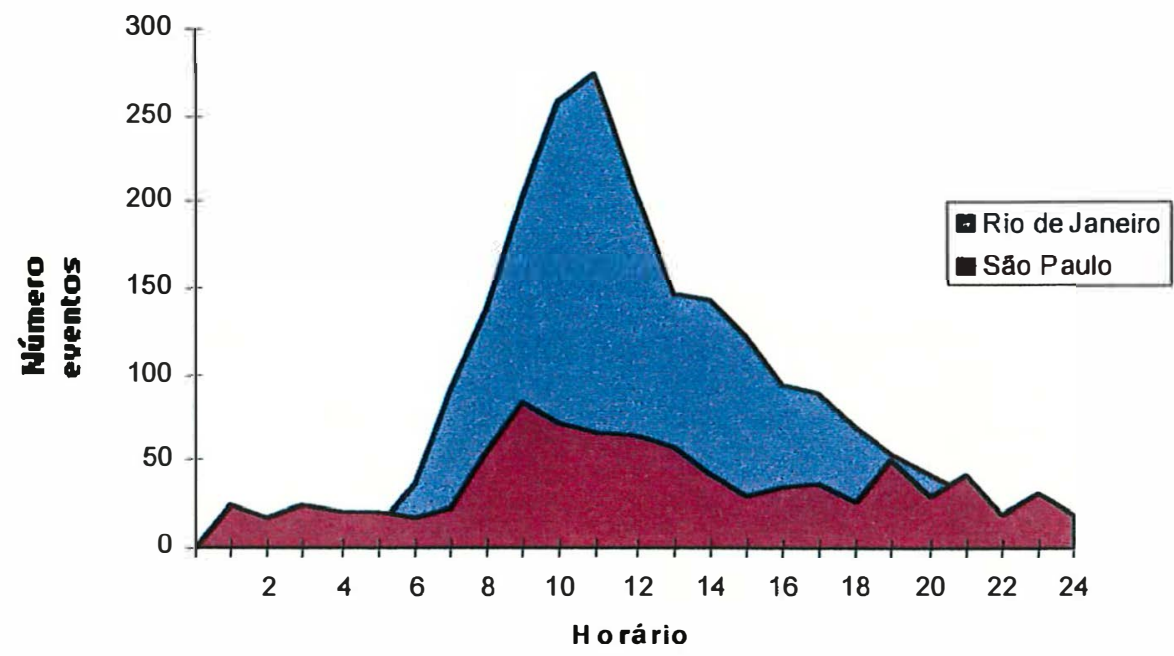

Figura 5. Horário de ocorrência de roubos de cargas, 1996 (Fonte: Assessorias de Segurança do SINDICARGA e SETCESP). 
Observa-se que há um pico de ocorrência dos roubos na parte da manhã, horário em que geralmente as mercadorias estão sendo entregues em seus destinos. No caso do Estado de São Paulo, verifica-se ainda que há algumas concentrações de roubos no final da tarde, por ocasião do recolhimento de mercadorias para entrega no dia seguinte.

As informações contidas nesta seção são relevantes para o conhecimento adequado do perfil do crime de roubo de cargas, e consequentemente, para servir de subsídio na formulação de programas de gerência de risco.

\subsubsection{Tendências}

O roubo de cargas vem sendo considerado, por alguns, como um dos principais crimes da atualidade. Segundo Mooney (1994), esse tipo de roubo deverá ficar conhecido como "o crime perfeito para os anos 90” (pág.59).

A severidade desse delito está superando, inclusive, o roubo a bancos, tradicionalmente conhecido como um dos grande crimes contra o patrimônio. A título de comparação, nos quatro primeiro meses do ano de 1998 ocorreram 501 assaltos a bancos no município de São Paulo ${ }^{11}$, totalizando aproximadamente US\$ 8 milhões; já os roubos de cargas, na mesma região, foram em número de 110, mas representando algo em torno de US\$ 13 milhões ${ }^{12}$. Isso mostra que o segundo tipo de delito já se apresenta mais importante que o primeiro em termos de valores envolvidos.

$\mathrm{Na}$ realidade, a tendência de aumento na importância do roubo de cargas já é esperada em virtude de algumas modificações tecnológicas e sócio-econômicas na economia mundial.

Primeiramente, o aumento das transações comerciais entre os Países, conhecido genericamente como "o fenômeno da globalização", incentiva uma maior troca de mercadorias, exigindo mais serviços de logística e, consequentemente, fazendo com que as mercadorias fiquem mais expostas aos riscos da atividade transporte.

\footnotetext{
"Sindicato dos Bancários de São Paulo (Lombardi, 1998).

${ }^{12}$ Estimativas baseadas nas informações estatísticas da Assessoria de Segurança do SETCESP.
} 
A globalização também ocorre no mundo do crime, fazendo com que o crime organizado cresça a proporções significativas, diversificando sua atividade, passando a atuar em vários segmentos e em diversos países. São exemplos dessas organizações: a Cosa Nostra, a Máfia Russa, os Chinese Triads, e os cartéis do México e América Latina.

Uma outra explicação surge da evolução tecnológica dos bens manufaturados, que agregam elevado valor monetário a materiais de pequenas dimensões, resultando em mercadorias de alto valor agregado, como os componentes eletrônicos, cujo exemplo mais comum é o do chip de computador.

Outro fator que pode ser considerado é o esforço das forças policiais e das punições severas em combater crimes tradicionais, tais como o roubo a bancos, e o narcotráfico, por exemplo. Essa repressão tende a desincentivar tais delitos, provocando uma alocação dos indivíduos criminosos em outras formas de crime, entre elas, o roubo de cargas.

A crise do poder público, verificada em quase todos os países em desenvolvimento - e muitas vezes nos próprios países desenvolvidos - também deve ser um dos motivos considerados. Em vários pontos, o Estado apresenta relação com o roubo de cargas.

Aspectos jurídicos, tais como as punições amenas, a morosidade nas condenações, e a dificuldade de enquadramento do receptor das mercadorias roubadas, acabam por não desestimular o crime de roubo de cargas no Brasil.

Há também questões tributárias relacionadas ao problema. Percebe-se uma relativa facilidade na falsificação de documentos legais - nota fiscal, por exemplo - das mercadorias roubadas. Além disso, o forte comércio informal existente no País acaba tornando-se um amplo mercado receptor dessas mercadorias.

Cite-se, ainda, aspectos de saúde pública. As mercadorias roubadas, muitas vezes, são manuseadas, armazenadas e comercializadas em condições inapropriadas, o que pode ocasionar problemas aos consumidores. São exemplos dessa situação, medicamentos e alimentos em estado de deterioração. A indiferença do Estado, 
verificada muitas vezes nas fiscalizações sanitárias, é um outro entrave no combate ao roubo de cargas.

A infra-estrutura viária é uma outra dimensão onde o Estado apresenta influência significativa. O desempenho do setor de transporte rodoviário de carga apresenta uma dependência fundamental dessas estruturas. Não apenas o sinistro "roubo de carga", mas também aqueles ocasionados por um simples acidente de tráfego, são fortemente dependentes dessas condições.

Uma última relação do roubo de cargas com o Estado, e talvez a mais evidente, é a segurança pública. A falta de segurança nas vias de tráfego acaba por não fornecer uma repreensão adequada ao crime. É formado, consequentemente, um ambiente propício à atuação dos criminosos que não encontram dificuldade alguma em suas ações.

\subsection{Carteira de Seguro de Transporte}

A característica inicial dos seguros de transporte, e que o faz mais complexo que os outros ramos, é a grande variedade de coberturas que existem e que são utilizadas em suas apólices. Essas apólices - instrumentos básicos de qualquer seguro - merecem atenção especial.

$\mathrm{Na}$ apólice constam todas as condições gerais e particulares do seguro, assim como as obrigações do segurado e do segurador. Nos seguros de transporte, são utilizados três tipos de apólices (Funenseg, 1994):

a) Apólice Simples: visa cobrir apenas um embarque, sendo recomendada para segurados que não efetuam embarque com frequência.

b) Apólice Aberta: recomendada para segurados que efetuam embarques com frequência, estabelece as condições gerais e particulares que regem todos os embarques.

c) Apólice Ajustável: concedida para segurados com grande movimento, estas apólices têm vigência anual e seu ajustamento é feito trimestralmente com base nos embarques efetivamente realizados, os quais o segurado compromete-se a informar mensalmente. 
No caso das apólices abertas e ajustáveis, o processo de comunicação dos embarques à seguradora é denominado averbação, na qual deve constar dados como data de saída, local de destino, identidade do veículo transportador, importância segurada, etc. São os tipos mais comuns, recebendo, consequentemente, maior atenção nesta análise.

Além do grande número de coberturas, mencionado anteriormente, essa peculiaridade das apólices deste seguro faz com que o mesmo seja considerado um seguro especializado, ou seja, não elementar, exigindo, portanto, maior conhecimento dos envolvidos, sejam eles os seguradores, os segurados ou também os corretores de seguro. Além do mais, sua natureza pode favorecer a prática de omissão das averbações, considerada ilícita e um sério problema da carteira. Nesses casos, nem todos os fretes são averbados, fazendo com que o prêmio pago à seguradora seja reduzido. Porém, quando da ocorrência de algum sinistro, a carga sinistrada é então averbada, visando a obtenção de indenização. Isso é possível devido à natureza das apólices (apólices abertas), onde muitas vezes a averbação chega à seguradora após o término do frete, permitindo, consequentemente, esse tipo de fraude.

É importante ressaltar contudo que, conforme Fischer (1985), as apólices abertas do seguro de transporte apresentam uma série de vantagens, tanto para o segurado como para o segurador. Para o primeiro, no sentido de que as condições são estabelecidas permanentemente, não exigindo perda de tempo com consultas e negociações com seu segurador cada vez que transporte determinada mercadoria. Além disso, os prêmios podem ser mais favoráveis devido ao maior volume e melhor equilíbrio para o segurador, o que também se caracteriza como uma vantagem para esse último. Esses prêmios são pagos em intervalos de tempo pré-determinados, não havendo a necessidade de desembolsos constantes.

A carteira de seguros de transporte no Brasil apresenta várias modalidades, ilustradas na Figura 6. 


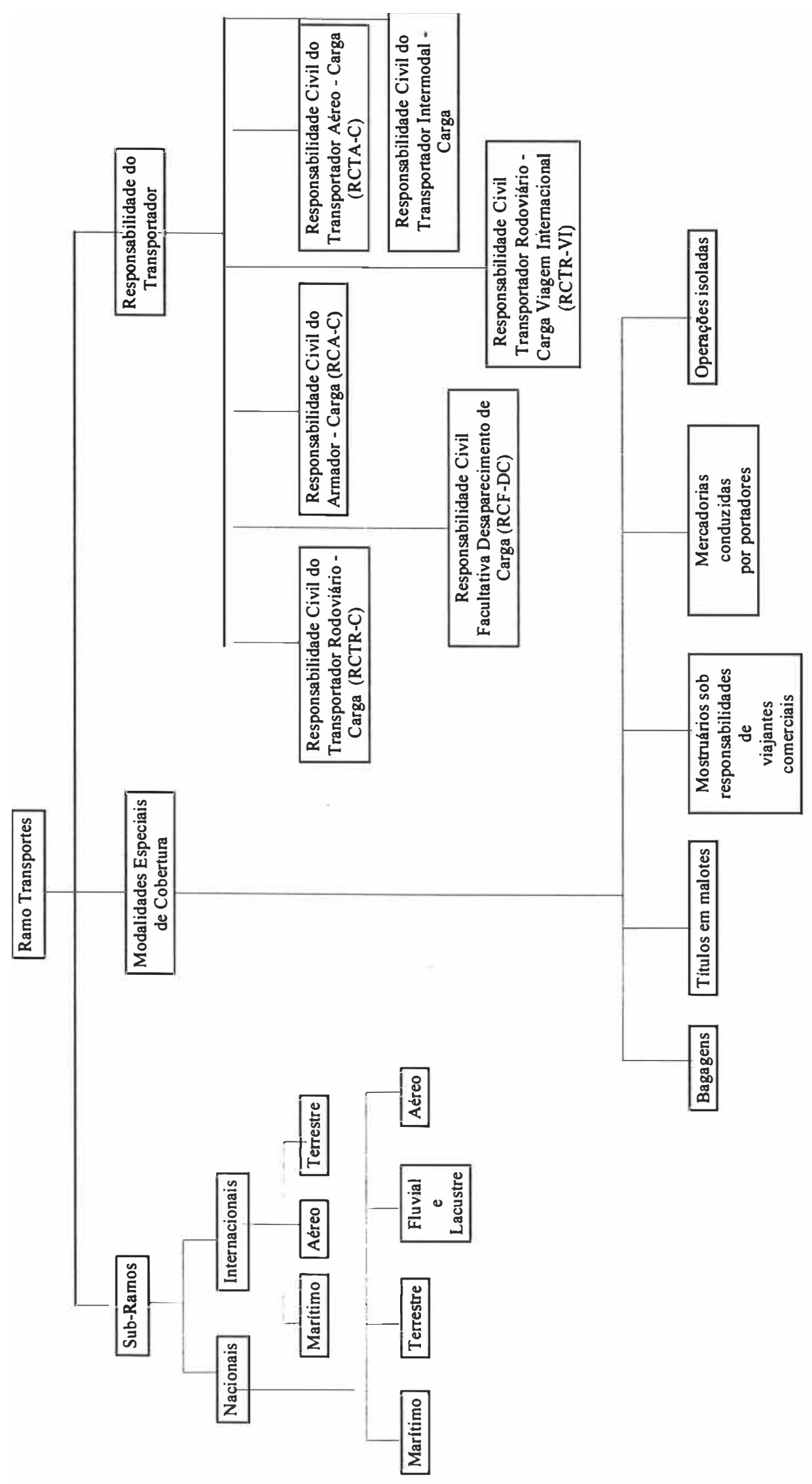

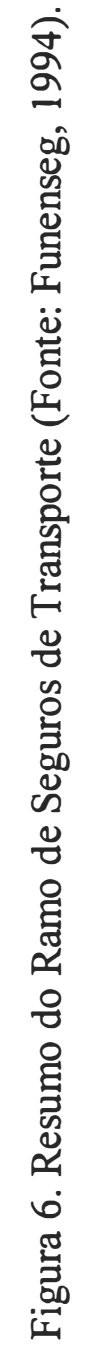


Os seguros que interessam ao desenvolvimento deste trabalho são os seguintes:

- Sub-Ramo Nacional Terrestre ${ }^{13}$, cuja cobertura básica é denominada de Riscos Rodoviários (RR);

- Responsabilidade Civil do Transportador Rodoviário - Carga (RCTR-C);

- Responsabilidade Civil Facultativa Desaparecimento de Carga (RCF-DC).

Para facilitar o entendimento, a Tabela 3 ilustra um resumo das principais características desses seguros.

Tabela 3: Características gerais dos seguros de carga para o Transporte Rodoviário.

\begin{tabular}{|c|c|c|}
\hline Seguro de Carga & A quem se destina & Cobertura \\
\hline \multirow[t]{2}{*}{$\begin{array}{l}\text { Riscos Rodoviários (RR) } \\
\text { (cobertura básica do } \\
\text { Seguro de Transporte } \\
\text { Nacional Terrestre) }\end{array}$} & $\begin{array}{l}\text { Obrigatório para } \\
\text { embarcadores. }\end{array}$ & $\begin{array}{l}\text { É um seguro all risks }{ }^{1} \text {. De uma maneira geral, não cobre } \\
\text { apenas o vício próprio da mercadoria, a imperícia, } \\
\text { imprudência ou negligência de transportadores e } \\
\text { embarcadores. }\end{array}$ \\
\hline & $\begin{array}{l}\text { Pode ser utilizado } \\
\text { por transportadores }\end{array}$ & $\begin{array}{l}\text { Cobre o roubo de cargas quando constatada a "força } \\
\text { maior". }\end{array}$ \\
\hline $\begin{array}{l}\text { Responsabilidade Civil } \\
\text { do Transportador } \\
\text { Rodoviário de Carga } \\
\text { (RCTR-C) } \\
\end{array}$ & $\begin{array}{l}\text { Obrigatório e } \\
\text { exclusivo para } \\
\text { transportadores }\end{array}$ & $\begin{array}{l}\text { Garante aos transportadores faltas e avarias sofridas } \\
\text { pelos bens que lhes são entregues para o transporte e } \\
\text { pelos quais sejam responsáveis em consequência, } \\
\text { basicamente de imperícia, imprudência ou negligência }\end{array}$ \\
\hline $\begin{array}{l}\text { Facultativo de } \\
\text { Responsabilidade Civil } \\
\text { do Transportador } \\
\text { Rodoviário por } \\
\text { Desaparecimento de } \\
\text { Carga (RCF-DC) } \\
\end{array}$ & $\begin{array}{l}\text { Facultativo e } \\
\text { exclusivo para } \\
\text { transportadores }\end{array}$ & $\begin{array}{l}\text { Garante aos transportadores as perdas ou danos } \\
\text { decorridos do desaparecimento da carga } \\
\text { concomitantemente com o veículo transportador, em } \\
\text { consequência de furto simples ou qualificado; roubo; } \\
\text { extorsão simples ou mediante sequestro; e apropriação } \\
\text { indébita. }\end{array}$ \\
\hline
\end{tabular}

'Espécie de seguro que cobre uma grande variedade de riscos.

Fonte: adaptado de Funenseg (1994) e Manual Transportes (1994).

${ }^{13}$ A partir deste momento, o Sub-Ramo Nacional Terrestre para o transporte rodoviário será genericamente denominado de "Seguro RR" para facilitar a comunicação. Deve ficar claro, todavia, que o termo "Riscos Rodoviários" (RR) é a denominação da cobertura básica desse seguro. 


\subsubsection{Sub-Ramo Nacional Terrestre (RR)}

O Sub-Ramo Nacional Terrestre engloba riscos ferroviários e rodoviários, sendo as coberturas básicas desses seguros genericamente denominadas de RF e RR, respectivamente. Essas coberturas cobrem os seguintes eventos:

- colisão, capotagem, descarrilamento e tombamento;

- incêndio, explosão, raio, inundação, transbordamento de cursos d'água, represas, lagos ou lagoas, desmoronamento ou queda de terras, pedras, obras de arte ou outros objetos;

- roubo oriundo de assalto à mão armada, ou desaparecimento de carregamento total do veículo devidamente comprovado por inquérito policial e extravio de volumes inteiros.

Conforme indica Martins (1993), a Legislação Brasileira impõe ao dono da mercadoria (embarcador) a obrigatoriedade da proteção de seus bens (Decreto $\mathrm{n}^{\circ}$ 61.867, de 07.12.1967):

Artigo $12^{\circ}$

“As pessoas jurídicas de direito público ou privado, são obrigadas a segurar os bens ou mercadorias de sua propriedade, contra riscos de força maior e caso fortuito, inerentes aos transportes ferroviários, rodoviários, aéreos e hidroviários, quando objeto de transporte no território nacional..."

Sendo assim, o Seguro de Riscos Rodoviários (RR) deve ser comprado por embarcadores por ocasião do transporte de suas mercadorias, independentemente do agente responsável pelo transporte das mesmas.

Dentre as coberturas citadas, algumas caracterizam-se pelo que se denomina de "caso fortuito" e "força maior". Essas figuras jurídicas são de fundamental importância e têm implicação direta na isenção da responsabilidade do transportador quando a esse é entregue uma mercadoria para o transporte. 
Além das coberturas básicas, outros riscos podem vir a ser cobertos mediante a inclusão de cláusulas especiais na apólice do seguro de transporte: água doce, amassamento, amolgamento, arranhadura, contaminação, contato com outras mercadorias, derrame, deterioração por congelamento, incêndio em armazém portuário, operações de carga e descarga, quebra, roubo, vazamento e outros danos não expressamente proibidos ${ }^{14}$.

Fica claro, portanto, que o seguro RR é um tipo denominado de all risks, ou seja, um seguro que cobre - via de regra - qualquer tipo de evento. Sendo assim, é possível - e ocorre em alguns casos - que os transportadores também o utilizem, objetivando uma cobertura mais abrangente. Isso porque os seguros de responsabilidade de transportadores cobrem apenas os sinistros causados por negligência, como será abordado oportunamente.

Uma característica importante da apólice de seguros terrestres é a sub-rogação de direitos. Em síntese, quando o segurador indeniza o segurado-embarcador por ocasião de determinado sinistro, aquele fica sub-rogado, de pleno direito, em todos os direitos e ações do segurado, contra aqueles que, por ato, fato, ou omissão, tenham causado os prejuízos indenizados pelo segurador.

Esse direito legal permite ao segurador do embarcador cobrar do transportador as provas de não responsabilidade, ou indenizações, quando da ocorrência de determinado sinistro por motivo de negligência do segundo. Surge, portanto, a fundamentação para a existência de seguros de responsabilidade dos transportadores, que objetivam exatamente protegê-los nesses casos.

Em relação aos critérios de taxação do seguro $R R$, a legislação impõe valores mínimos de taxas básicas e adicionais. Há também limites para descontos e acréscimos nessas taxas. A esse seguro é, portanto, permitida a prática de tarifações especiais.

\footnotetext{
${ }^{14}$ Esses riscos são automaticamente cobertos - ou seja, não exigem cláusulas especiais - quando decorrerem de riscos previstos nas condições básicas.
} 
A título de comparação, nos Estados Unidos, o seguro de transporte terrestre, denominado de Inland Marine ${ }^{15}$ ou ainda mais genericamente, Transportation Insurance, apresenta características bastante semelhantes ao seguro brasileiro. A diferença básica é que a contratação desse seguro não é obrigatória aos embarcadores, como ocorre no Brasil. Além disso, toda a regulamentação é feita nas esferas estaduais, havendo grande variação de estado para estado, diferentemente no Brasil, onde essa regulamentação é Federal.

Segundo Trieschmann et al. (1994), o que leva o embarcador a contratar o seguro nos Estados Unidos é o fato de que a responsabilidade dos transportadores é limitada e, mesmo que comprovada, pode haver dificuldade na obtenção da indenização por parte do transportador, que muitas vezes encontra-se em condições financeiras desfavoráveis. Os autores ainda afirmam que, geralmente, os próprios termos de compra obrigam uma das partes - embarcador ou transportador - a contratar o seguro por ocasião do transporte.

De uma forma geral, os seguros de transporte nos Estados Unidos são pouco regulamentados em relação às taxas cobradas por seguradores e à forma das apólices em função justamente da característica intrínseca da atividade de transporte, exposta a inúmeros riscos, tal como já comentado.

Para o seguro de responsabilidade de transportadores, contudo, há maiores exigências por parte da regulamentação, que serão abordadas a seguir.

\subsubsection{Seguro de Responsabilidade Civil do Transportador Rodoviário de Carga (RCTR-C)}

O RCTR-C tem como objetivo segurar o transportador contra perdas ou danos que venham a ocorrer com os bens que estavam sob sua responsabilidade por ocasião do transporte.

\footnotetext{
15 Mesmo que o termo "Marine" sugira algo relacionado ao mar, a expressão "Inland Marine" ficou consagrada nos Estados Unidos para o seguro de transporte terrestre, visto esse seguro ter se originado do transporte maritimo.
} 
Quando um determinado bem ou mercadoria é entregue a um transportador, a legislação impõe - pelo Decreto Lei no 73, de 21.11.66 e Decreto no 61.867, de 07.12.67 - a sua responsabilidade sobre esses bens e mercadorias. Isso faz com que o transportador procure se proteger das consequências através do seguro de responsabilidade civil.

A responsabilidade do transportador não é presumida apenas em situações previstas em lei e que se resumem em casos fortuitos, força maior, culpa do próprio embarcador ou vício próprio da coisa transportada (Martins, 1993).

O seguro RCTR-C tem por fim garantir aos transportadores rodoviários as faltas e avarias sofridas pelos bens que lhes são entregues para transporte e pelos quais sejam responsáveis em consequência, basicamente, de imperícia, imprudência ou negligência.

Alguns comentários a respeito do que se entende por "caso fortuito" e "força maior" são necessários.

Quando se analisa qualquer forma de contrato - no caso desta pesquisa, o contrato de seguro - é fundamental a abordagem dessas figuras jurídicas.

Essas duas figuras são, por lei, capazes de excluir a obrigação do contratante diante do acontecimento de determinados eventos, no caso, a obrigação dos transportadores sobre mercadorias de terceiros que lhes são entregues para o transporte. Há uma variedade de concepções em torno dessas figuras, sendo que o principal ponto de conflito está na diferenciação conceitual entre elas. França (1977) apresenta uma visão interessante a respeito dessas discussões:

"No fundo tudo isso se depararia, em verdade, com um mesmo substractum comum: o da ausência de toda e qualquer culpa por parte do responsável nas hipóteses do fortuito, como no da força maior, vinculadas à impossibilidade absoluta de cumprir, o interessado, aquilo por que se obrigou" (pág. 246).

Portanto, ainda que na prática a consequência de ambos seja a mesma, o evento "roubo de carga" ou, mais genericamente "desvio de carga", pode apresentar relação com a força maior e não com o caso fortuito, pois mesmo que não se saiba exatamente quando 
podem ocorrer, o fato é que são previsíveis, descartando o enquadramento como caso fortuito, que exige que o evento seja imprevisível. Por outro lado, tais eventos podem ser considerados como força maior quando não há forma de serem evitados.

Ficaria, portanto, caracterizada a força maior no caso de roubo de carga quando, de fato, ao transportador nada foi possível fazer para evitar o sinistro, como por exemplo, mediante um assalto à mão armada.

É importante que fique claro que, se a negligência - contemplada no artigo 104 do Código Civil - vier precedida da força maior, aquela prevalece, não liberando, consequentemente, o transportador da responsabilidade:

$\mathrm{O}$ artigo 104 apresenta o seguinte texto:

"...se, todavia, se provar que para a perda ou avaria dos gêneros interveio negligência ou culpa do condutor ou comissionário de transportes, por ter deixado de empregar as precauções e diligências praticadas em circunstâncias idênticas por pessoas diligentes (art. 99), será este obrigado à sua indenização, ainda mesmo que tenha provindo de caso fortuito ou da própria natureza da coisa carregada".

A negligência é, em consequência, um fator determinante na designação da responsabilidade ao transportador, sendo inclusive superior à ocorrência do fortuito, como já comentado.

Os agentes transportadores deveriam estar cientes disso, pois insistentemente lutam por livrar-se dessa responsabilidade, alegando que a força maior - por si só - libertá-los-ia da obrigação.

Eis aqui o ponto central da discussão: ao transportador caberá a prova de que não agiu negligentemente para a ocorrência do roubo de carga. Isso naturalmente converge para discussões jurídicas que, além de onerosas, são geralmente desgastantes.

Porém, mesmo que fique comprovada a culpa do transportador, isso não exime a importância do seguro do embarcador, que evita a esse agente incorrer em custos e trâmites jurídicos no sentido de cobrar do primeiro as indenizações necessárias, pois seria 
indenizado por seu segurador independentemente da comprovação da culpa do transportador.

Além de representar custos financeiros, discussões jurídicas são conflitos que normalmente fazem com que os clientes-embarcadores deixem de trabalhar com aquele transportador. E, dadas as características de competição quase perfeita do setor de transporte rodoviário de carga - como mencionado no item 1.2 - a escolha de outro transportador torna-se uma decisão fácil ao embarcador.

Outro ponto importante refere-se à exigência legal para a compra do RCTR-C que, assim como o RR, também é um seguro obrigatório, sendo igualmente imposto pelo Decreto $n^{\circ}$ 61.867, de 07.12.1967 (Martins, 1993):

Artigo $10^{\circ}$

"As pessoas físicas ou jurídicas, de direito público ou privado, que se incumbirem do transporte de carga, são obrigadas a contratar seguro de responsabilidade civil em garantia das perdas e danos sobrevindos à carga que lhes tenha sido confiada para transporte, contra conhecimento ou nota de embarque."

Em relação à sua taxação, o seguro RCTR-C apresenta-se bastante rígido, não sendo permitida a "...concessão de qualquer desconto, nem mesmo pelo pagamento do prêmio à vista, ou qualquer outra vantagem ao segurado, direta ou indiretamente" (Manual Transportes, 1994).

Objetivando um melhor entendimento da responsabilidade dos transportadores, buscou-se na literatura informações a esse respeito em outros países e modais de transporte.

Essas responsabilidades geralmente são consagradas em leis nacionais de cada país. Por exemplo, para o transporte marítimo, as responsabilidades do transportador estão dispostas no Carriage of Goods By Sea Act, na Inglaterra, e no Harter Act, nos Estados Unidos. 
São estabelecidos, ainda, convênios internacionais - denominados "convenções" nos quais os transportadores dos países signatários comprometem-se a seguir as normas estabelecidas. Tais convenções são mais comuns para transportes internacionais marítimos ("Convenção Internacional de Bruxelas", de 1924), e internacionais aéreos ("Convenção Internacional de Varsóvia", de 1929).

Em síntese, as convenções pregam a isenção da responsabilidade do transportador sempre que os sinistros não decorrerem da negligência do transportador e de seus prepostos. Além disso, geralmente limitam a responsabilidade por volume transportado, quando da não declaração do valor da mercadoria e salvo quando expresso em contrário, nos conhecimentos de embarque.

No caso da Convenção de Bruxelas, a responsabilidade do transportador marítimo é fixada em 100 Libras por unidade de volume (Fischer, s.d.). Os Estados Unidos limitam a responsabilidade do transportador marítimo em US\$ 500/unidade. Atualmente, as unidades mais comuns são os conteiners (Funenseg, 1994).

Em todos esses casos, e assim como no caso do transporte rodoviário de carga no Brasil, ao transportador cabe provar sua imunidade quando da ocorrência de determinado sinistro envolvendo a carga, vista sua culpa ser sempre presumida.

Para o transporte aéreo internacional de mercadorias, a base das legislações nacionais é a Convenção de Varsóvia, já mencionada. As responsabilidades e imunidades são muito semelhantes às da Convenção de Bruxelas. Para o transporte de mercadorias sem valor declarado, o convênio limita a responsabilidade a um valor de US\$ 20 por quilo de mercadoria transportada. O Governo Brasileiro, diferentemente da Convenção de Bruxelas, é signatário da Convenção de Varsóvia.

Para os transportes rodoviários, não se conhece convenções nesses moldes, sendo as responsabilidades dos transportadores dispostas nos códigos civis de cada país.

O que chama a atenção nessa breve comparação entre as responsabilidades dos transportadores nos diferentes modais para o transporte internacional é o fato da limitação dessa responsabilidade, através da fixação de valores mínimos e/ou máximos por 
determinada unidade de mercadoria, quando da não declaração do valor das mesmas por ocasião de seu embarque. Isso não ocorre no transporte rodoviário de carga, para o qual a responsabilidade do transportador é automaticamente limitada ao valor integral da carga.

Nos Estados Unidos ${ }^{16}$, o funcionamento dos seguros de responsabilidade civil de transportadores guarda algumas diferenças com o Brasil, isso porque a forte regulamentação estatal no setor de transporte rodoviário de carga naquele País criou dois grandes grupos de transportadores, cujas responsabilidades diferem sensivelmente: common carrier e contract carrier.

Na prática, há pouca distinção entre os dois tipos de transportadores. Os common carriers prestam serviço ao público em geral, enquanto que os contract carriers, como sugere o próprio nome, atuam com um público restrito e mediante o firmamento de contratos de transporte. A responsabilidade, contudo, difere significativamente.

No caso dos primeiros, a sua responsabilidade é geralmente maior, sendo que há apenas 5 grupos de sinistros cuja culpa não é presumida: os chamados act of God (furacões, enchentes, e outras convulsões da natureza), negligência do embarcador (mau acondicionamento das mercadorias, por exemplo), riscos de guerra, atos de autoridades públicas (confisco, etc.) e vício próprio da mercadoria. Portanto, o common carrier é responsável pela carga - entre outros - nos casos de roubo ou desvio da mesma, mesmo que tenha sido caracterizada a situação de força maior.

Porém, a legislação norte-americana permite que a responsabilidade desses transportadores seja limitada mediante a inclusão de cláusulas especiais no contrato de frete. Quando isso ocorre, geralmente há uma diminuição nos valores dos fretes. Esse tipo de negociação é bastante comum entre embarcadores e transportadores.

Por sua vez, a responsabilidade dos contract carriers é toda ela estipulada nos contratos firmados entre embarcadores e transportadores. Os termos nos contratos podem variar significativamente em cada caso. Normalmente, a responsabilidade dos

\footnotetext{
${ }^{16}$ Essas informações foram obtidas em Trieschmann et al. (1994) e complementadas através de contatos via $e$ mail com pesquisadores do American Institute for Chartered Property Casualty Underwriter.
} 
transportadores, estipulada nos contratos, restringe-se aos casos de negligência, à semelhança do que ocorre no Brasil. Portanto, os casos de roubo e desvio de carga caracterizados por força maıor, na ausência da negligência, estariam fora da responsabilidade desses transportadores.

Independentemente do tipo de transportador, a legislação federal norte-americana exıge a contratação de seguro de responsabilidade de transportadores para o transporte interestadual, sobre um valor mínimo de aproximadamente US\$ 5 mil por veículo. As legislações estaduais, por sua vez, podem variar.

O importante é que, nos Estados Unidos, a flexibilidade na contratação do seguro de responsabilidade de transportadores permite a prática de prêmios mais adequados para cada uma das situações. Existem ainda os underwriters, uma espécie de corretores de seguros que apresentam a função de procurar no mercado o seguro mais adequado a cada indivíduo ou empresa.

Essa flexibilidade na formatação da apólice e na estipulação dos prêmios praticamente não ocorre para o seguro RCTR-C no Brasil, onde as condições e taxas são pré-estipuladas pela regulamentação federal.

Em relação ao serviço de corretagem, já existem no Brasil empresas especializadas no assunto, que prestam um serviço diferenciado aos transportadores. Porém há muitos corretores que não apresentam tal especialização e que, consequentemente, não atendem às reais necessidades dos usuários de seguro de carga.

\subsubsection{Seguro Facultativo de Responsabilidade Civil do Transportador Rodoviário por Desaparecimento de Carga (RCF-DC)}

Esse seguro foi instituído no Brasil em meados dos anos oitenta em decorrência do aumento crescente do desaparecimento de cargas, seja pelo desaparecimento por ação dolosa do motorista, seja por assalto à mão armada (Funenseg, 1994). 
Esse seguro garante ao segurado o reembolso das reparações pecuniárias pelas quaıs, por disposições legais, for ele responsável, em virtude das perdas ou danos que decorram do desaparecimento de carga concomitantemente com o veículo transportador em consequência de furto simples ou qualificado, roubo, extorsão simples ou mediante sequestro, apropriação indébita decorrente, ou não, de falsidade ideológica (Manual Transportes, 1994).

O RCF-DC difere do RCTR-C portanto, no que se refere à cobertura, sendo específico para os casos de roubo, furto e desvio de carga. Além disso, é um seguro facultativo, ao contrário do RCTR-C que trata-se de um seguro obrigatório.

No ano de 1995, as condições gerais e tarifárias do RCF-DC sofreram algumas modificações com o objetivo básico de esclarecer as condições de cobertura, em vista das inúmeras discussões jurídicas que ocorreram no setor. Logo, as coberturas mencionadas no parágrafo anterior, foram assim especificadas ${ }^{17}$ :

- Apropriação indébita e estelionato, quando do desaparecimento da carga for concomitante com o do veículo transportador;

- Furto simples ou qualificado, ou extorsão simples ou mediante sequestro, quando o desaparecimento da carga for concomitante com o do veículo transportador;

- Roubo durante o trânsito, entendendo-se como tal, para caracterização da cobertura, o desaparecimento total ou parcial da carga, desde que o autor do delito tenha assumido o controle do veículo transportador, mediante grave ameaça ou emprego de violência contra o motorista, determinando sua ação, não compreendendo porém, roubo de veículos carregados total ou parcialmente, enquanto estacionados no interior de depósitos ou da área de terreno onde estiverem localizados os depósitos do segurado e listados na apólice;

- Roubo no depósito do transportador, listado na apólice, assim entendido o roubo de mercadorias de terceiros, nos pátios, no interior dos edificios ou carregados

\footnotetext{
${ }^{17}$ Essas coberturas foram extraídas do Manual Transportes, 1994.
} 
no veículo transportador, ainda não entregues ao destinatário, desde que acompanhados de documento fiscal ou de controle e, ainda, que não tenha permanecido no depósito por mais de 15 (quinze) dias corridos.

Há também uma série de exigências que o transportador deve atender para a utilização deste seguro, tais como a manutenção de um cadastro com motoristas e veículos transportadores, exigência de vários documentos dos transportadores, aviso imediato à seguradora quando no caso de interrupção de viagem ou demora no prazo normal, facilitação dos trabalhos de investigação quando da ocorrência de sinistro, etc.

A participação obrigatória ${ }^{18}$ do segurado é outra característica relevante do RCFDC. A princípio, essa participação era de $25 \%$, podendo variar de $20 \%$ a $30 \%$, conforme condições especiais. Com as modificações de 1995, a participação obrigatória do transportador, no caso de transporte de medicamentos e cigarros, ficou estabelecida em $30 \%$, ou $36 \%$ quando incluída a cobertura nos depósitos do transportador. Tais modificações prevêem também a redução de $50 \%$ na participação obrigatória caso algumas exigências sejam atendidas.

As taxas básicas do RCF-DC eram de 0,04\% para mercadorias em geral, e de 0,20\% para mercadorias específicas. Em 1995, essas taxas passaram para 0,06\% e 0,09\%, respectivamente. Ressalta-se, contudo, uma importante alteração, que foi o estabelecimento de uma lista de mercadorias que são automaticamente excluídas da cobertura do RCF-DC, salvas condições especiais estipuladas na apólice. Essas mercadorias são: armas, armamentos e munições, autopeças, brinquedos, calçados, charques e carnes "in natura", confecções e tecidos, couro beneficiado, cigarros, eletrodomésticos/eletrônicos, leite em pó ou condensado, medicamentos, óleos comestíveis, óleos lubrificantes, pneus e câmaras de ar, e tintas.

\footnotetext{
${ }^{18}$ Participação obrigatória é aquela em que o segurado assume parte do risco, ou seja, o seguro não apresenta cobertura completa. Geralmente essa participação é estipulada através de uma porcentagem. Por exemplo, uma participação obrigatória de $20 \%$ significa dizer que, em caso de sinistro, o seguro irá ressarcir apenas $80 \%$ do valor da perda, enquanto os outros $20 \%$ ficam a cargo do segurado.
} 
Em relação às exigências legais, o seguro RDF-DC é facultativo - como o próprio nome diz - e só poderá ser contratado em conjunto com o RCTR-C.

\subsection{Mercado Segurador Brasileiro}

O ambiente sócio-econômico do País passa por uma sensível mudança, no qual todos os setores da economia acabam sendo afetados, não sendo diferente para o mercado de seguros.

No ano de 1966, através do Decreto-Lei $\mathrm{n}^{\circ} 73$, o Governo Brasileiro deu um importante passo na reformulação do setor, que era composto por várias empresas sem uma adequada base de capital, algumas delas carentes de idoneidade empresarial mínima. Naquele mesmo ano, foi criada a Superintendência de Seguros Privados (SUSEP) com o objetivo de fixar as diretrizes da política de seguros privados no País. A SUSEP - até hoje - ainda é um exemplo concreto da forte atuação do Estado na regulamentação do setor (Conjuntura Econômica, 1998).

Essa forte atuação do governo marcou o setor até o início dos anos 90, uma vez que, a legislação de seguros era claramente inibidora da iniciativa privada e da livre concorrência.

O índice mais utilizado para medir o desempenho do mercado de seguros é a razão entre prêmios recebidos e Produto Interno Bruto (PIB). No Brasil, até os anos 90, essa relação sempre esteve em torno de $1 \%$. A Tabela 4 ilustra a participação do mercado segurador no PIB nacional a partir de 1990. Observa-se, através dos dados da tabela, que apenas a partir do ano de 1994 tal relação superou os $2 \%$. 
Tabela 4. Participação do Mercado Segurador no Produto Interno Bruto do Brasil.

\begin{tabular}{cccc}
\hline Ano & $\begin{array}{c}\text { Prêmios Emitidos } \\
\text { (US\$ Milhões) }\end{array}$ & $\begin{array}{c}\text { PIB } \\
\text { (US\$ Milhões) }\end{array}$ & $\begin{array}{c}\text { Participação no PIB } \\
(\%)\end{array}$ \\
\hline 1990 & 5.968 & 445.919 & 1,34 \\
1991 & 5.140 & 368.185 & 1,40 \\
1992 & 5.285 & 374.324 & 1,41 \\
1993 & 5.560 & 430.266 & 1,29 \\
1994 & 11.869 & 561.305 & 2,11 \\
1995 & 14.718 & 718.490 & 2,04 \\
1996 & 14.748 & 724.195 & 2,03 \\
$1997^{*}$ & 16.213 & 685.834 & 2,36
\end{tabular}

Fonte: Federação Nacional das Empresas de Seguros Privados e de Capitalização (Fenaseg). In homepage: www. fenaseg.org.br (1998).

*Valores ainda sujeitos a ajuste.

Além da forte intervenção governamental já mencionada, a instabilidade econômica sempre foi outro entrave ao desenvolvimento do setor. Se por um lado os altos índices de inflação no País inibiam fortemente esse mercado - pois as indenizações não eram corrigidas até meados do ano de 1987 - também acabou sustentando as empresas seguradoras através dos excelentes resultados financeiros, já que os resultados operacionais seguidamente ficavam abaixo do desejável (Conjuntura Econômica, 1998).

Essa idéia de que a não correção monetária das indenizações foi um dos principais motivos da estagnação do mercado segurador no Brasil até os anos oitenta, é seguidamente corroborada como verdadeira. Todavia, Cunha (1995) elaborou um minucioso estudo a esse respeito, chegando à seguinte conclusão:

"Não se pode afirmar, com base no modelo e nos dados reais disponíveis, que a inflação foi a principal - muito menos a única causa da reduzida dimensão do mercado de seguros no Brasil no período em que as apólices não eram indenizadas" (pág. 144).

Outra causa geralmente levantada para explicar a estagnação do mercado segurador até o início da década é o baixo nível de renda da população brasileira, aliado à inexistência 
de uma cultura consumidora de seguro, ou seja, trata-se da idéia já consagrada de que o seguro é um bem superior. Ainda que a razão prêmio/PIB até a década de oitenta não tenha mostrado claramente essa tendência, isso parece estar se confirmando a partir da década atual, na qual o aumento no consumo de seguro foi proporcionalmente maior que o aumento da renda (PIB).

A partir dos anos 90, a concepção liberal, a maır abertura do mercado e a estabilidade da economia, encarregaram-se de gerar profundas modificações e progressos no setor, tendência essa em plena evidência na atualidade. Um passo fundamental nesse sentido foi o lançamento do Plano Diretor do Mercado de Seguros, em 1992 (Conjuntura Econômica, 1998).

O serviço de resseguro no Brasil também passa por sensíveis modificações. Resseguro, para Cerne (1973), é um contrato pelo qual um ressegurador assume, mediante remuneração, o total ou parte dos riscos assumidos por um segurador, obrigando-se a embolsá-lo em condições predeterminadas, quando da ocorrência de um sinistro coberto pelo segurador. Em outras palavras, Resseguro é o seguro do segurador.

Foi apenas no ano de 1997 que o monopólio do resseguro foi quebrado, permitindo a atuação de outras empresas no País. O Instituto de Resseguros do Brasil (IRB) atualmente com a denominação de IRB-Brasil Re S.A. - era a única empresa com autorização para atuar nesse mercado. Essa empresa, de capital misto, com atuação claramente estatal, deverá ser privatizada nos próximos anos.

Segundo a Conjuntura Econômica (1998), a proteção do monopólio do resseguro limitou a competitividade do IRB, fazendo com que seus custos ficassem muito elevados. Mais ainda, os planos oferecidos às seguradoras eram pouco diferenciados em termos de coberturas e tarifas, não atendendo às exigências do mercado.

No que se diz respeito à estrutura do mercado segurador propriamente dito, há no Brasil um total de 130 empresas em atividade, incluindo empresas de capitalização e previdência privada (muitas delas fazem parte de um mesmo grupo empresarial). 
A Figura 7 ilustra os percentuais do prêmio total - por ramo - auferidos pelas companhias seguradoras no ano de 1997.

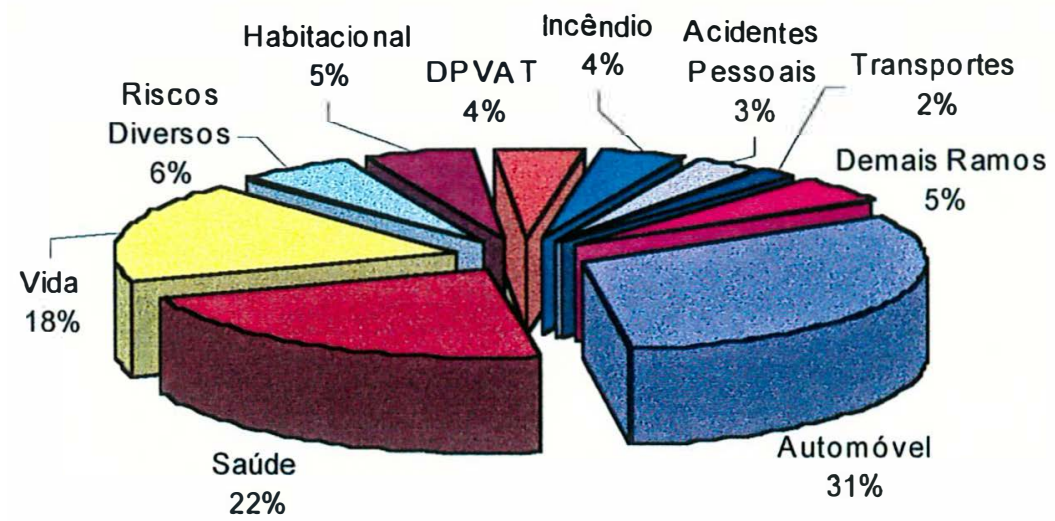

Figura 7. Percentual do Prêmio Total, por Ramo, para o ano de 1997 (Fonte: Fenaseg. In homepage: www.fenaseg.org.br, 1998)

O ramo denominado de "Transportes" engloba apenas os seguros de transporte propriamente ditos, e não aqueles de responsabilidade civil dos transportadores, que estão incluídos nos chamados "Demais Ramos".

Portanto, o ramo "Transportes" abrange os seguros de Transporte Nacional, Intermodal e Internacional. São os seguros denominados genericamente de "seguros dos embarcadores". Observa-se que a participação desse ramo é da ordem de 2 a 3\%, percentual este que vem se mantendo constante nos últimos anos (média de 2,6\% no período 19931997).

Por sua vez, os seguros de responsabilidade dos transportadores estão incluídos no segmento "Demais Ramos", que totalizaram 5\% do total de prêmios do setor para o ano de 1997.

A Tabela 5 traz várias informações relevantes, com destaque para a comparação do montante dos prêmios da carteira Transportes Nacionais com o da RCTR-C e RCF-DC. 
Tabela 5. Prêmio Total e participação no total do ramo, para os ramos "Transportes" de "Demais Ramos".

\begin{tabular}{|c|c|c|c|c|c|c|c|c|}
\hline \multirow[b]{2}{*}{ RAMO } & \multicolumn{2}{|c|}{1994} & \multicolumn{2}{|c|}{1995} & \multicolumn{2}{|c|}{1996} & \multicolumn{2}{|c|}{1997} \\
\hline & $\begin{array}{c}\text { Prêmio } \\
\text { Total } \\
\text { (RS Mil) }\end{array}$ & $\begin{array}{l}\% \text { no } \\
\text { Ramo }\end{array}$ & $\begin{array}{c}\text { Prêmio } \\
\text { Total } \\
\text { (RS Mil) }\end{array}$ & $\begin{array}{l}\% \text { no } \\
\text { Ramo }\end{array}$ & $\begin{array}{c}\text { Prêmio } \\
\text { Total } \\
\text { (RS Mil) }\end{array}$ & $\begin{array}{l}\text { \% no } \\
\text { Ramo }\end{array}$ & $\begin{array}{c}\text { Prêmio } \\
\text { Total } \\
\text { (RS Mil) }\end{array}$ & $\begin{array}{l}\% \text { no } \\
\text { Ramo }\end{array}$ \\
\hline TRANSPORTE INTERMODAL & 1.750 & $0,57 \%$ & 777 & $0,21 \%$ & 1.320 & $0,38 \%$ & 1.289 & $0,34 \%$ \\
\hline TRANSPORTE INTERNACIONAL & 171.927 & $56,32 \%$ & 210.812 & $57,91 \%$ & 190.372 & $54,39 \%$ & 201.397 & $52,63 \%$ \\
\hline TRANSPORTE NACIONAL & 131.612 & $43,11 \%$ & 152.419 & $41,87 \%$ & 158.331 & $45,23 \%$ & 179.963 & $47,03 \%$ \\
\hline TOTAL TRANSPORTE & 305.288 & $100,00 \%$ & 364.008 & $100,00 \%$ & 350.023 & $100,00 \%$ & 382.649 & $100,00 \%$ \\
\hline AERONAUTICOS & 159.776 & $18,36 \%$ & 88.397 & $11,14 \%$ & 84.372 & $11,24 \%$ & 96.438 & $11,19 \%$ \\
\hline ANIMAIS & 4.930 & $0,57 \%$ & 2.022 & $0,25 \%$ & 772 & $0,10 \%$ & 994 & $0,12 \%$ \\
\hline CASCOS & 68.484 & $7,87 \%$ & 42.168 & $5,31 \%$ & 35.439 & $4,72 \%$ & 32.916 & $3,82 \%$ \\
\hline COMPREENSIVO DE FLORESTAS & 255 & $0,03 \%$ & 3.784 & $0,48 \%$ & 307 & $0,04 \%$ & 240 & $0,03 \%$ \\
\hline CREDITO INTERNO & 17.488 & $2,01 \%$ & 48.593 & $6,12 \%$ & 43.157 & $5,75 \%$ & 86.390 & $10,02 \%$ \\
\hline D. P. E. M. & 2.943 & $0,34 \%$ & 2.932 & $0.37 \%$ & 3.422 & $0,46 \%$ & 3.642 & $0,42 \%$ \\
\hline FIANCA LOCATICIA & 22.346 & $2,57 \%$ & 14.833 & $1,87 \%$ & 18.617 & $2,48 \%$ & 21.250 & $2,47 \%$ \\
\hline FIDELIDADE & 1.324 & $0,15 \%$ & 1.468 & $0,19 \%$ & 948 & $0,13 \%$ & 814 & $0,09 \%$ \\
\hline GARANTIA & 5.287 & $0,61 \%$ & 18.756 & $2,36 \%$ & 35.698 & $4,76 \%$ & 52.791 & $6,12 \%$ \\
\hline GLOBAL DE BANCOS & 17.137 & $1.97 \%$ & 47.117 & $5,94 \%$ & 29.393 & $3,92 \%$ & 17.726 & $2,06 \%$ \\
\hline LUCROS CESSANTES & 27.447 & $3,15 \%$ & 16.055 & $2,02 \%$ & 8.620 & $1,15 \%$ & 6.671 & $0,77 \%$ \\
\hline P.C.H.V. & 307 & $0,04 \%$ & 93 & $0,01 \%$ & 173 & $0,02 \%$ & 78 & $0,01 \%$ \\
\hline PENHOR RURAL & 31.316 & $3,60 \%$ & 36.437 & $4.59 \%$ & 16.223 & $2,16 \%$ & 27.564 & $3,20 \%$ \\
\hline RCTR-C & 152.466 & $17,52 \%$ & 165.135 & $20,81 \%$ & 177.019 & $23,58 \%$ & 187.805 & $21,79 \%$ \\
\hline $\mathrm{RCA}-\mathrm{C}$ & 1.482 & $0,17 \%$ & 1.081 & $0,14 \%$ & 752 & $0,10 \%$ & 1.300 & $0,15 \%$ \\
\hline RCF-DC & 60.382 & $6,94 \%$ & 81.538 & $10,27 \%$ & 96.547 & $12,86 \%$ & 102.122 & $11,85 \%$ \\
\hline RCTA-C & 0 & $0,00 \%$ & 59 & $0.01 \%$ & 359 & $0,05 \%$ & 892 & $0,10 \%$ \\
\hline RCTR-VI & 8 & $0,00 \%$ & 88 & $0,01 \%$ & 203 & $0,03 \%$ & 542 & $0,06 \%$ \\
\hline RESPONSABILIDADE CIVIL GERAL & 80.076 & $9,20 \%$ & 77.244 & $9,73 \%$ & 79.350 & $10,57 \%$ & 85.257 & $9,89 \%$ \\
\hline RISCOS DE ENGENHARIA & 105.380 & $12,11 \%$ & 78.950 & $9.95 \%$ & 61.018 & $8,13 \%$ & 84.077 & $9,75 \%$ \\
\hline RISCOS DE PETROLEO & 39.415 & $4,53 \%$ & 17.479 & $2.20 \%$ & 16.499 & $2,20 \%$ & 17.577 & $2,04 \%$ \\
\hline RISCOS DO EXTERIOR & 25.011 & $2,87 \%$ & 13.229 & $1.67 \%$ & 9.144 & $1,22 \%$ & 1.161 & $0,13 \%$ \\
\hline RISCOS NUCLEARES & 5.665 & $0,65 \%$ & 709 & $0,09 \%$ & 3.453 & $0,46 \%$ & 2.920 & $0,34 \%$ \\
\hline RISCOS RURAIS & 7.430 & $0,85 \%$ & 6.791 & $0,86 \%$ & 6.296 & $0,84 \%$ & 8.152 & $0,95 \%$ \\
\hline ROUBO & 24.802 & $2,85 \%$ & 22.698 & $2,86 \%$ & 16.749 & $2,23 \%$ & 15.184 & $1,76 \%$ \\
\hline SUCURSAIS NO EXTERIOR & 3.644 & $0,42 \%$ & 1.989 & $0,25 \%$ & 871 & $0,12 \%$ & 1.050 & $0,12 \%$ \\
\hline TUMULTOS & 2.032 & $0.23 \%$ & 816 & $0,10 \%$ & 387 & $0,05 \%$ & 161 & $0,02 \%$ \\
\hline TURÍSTICO & 2.406 & $0,28 \%$ & 2.570 & $0.32 \%$ & 4.522 & $0,60 \%$ & 6.102 & $0,71 \%$ \\
\hline VIDROS & 837 & $0,10 \%$ & 531 & $0.07 \%$ & 365 & $0,05 \%$ & 249 & $0,03 \%$ \\
\hline TOTAL DEMAIS RAMOS (1) & 870.075 & $100,00 \%$ & 793.563 & $100,00 \%$ & 750.673 & $100,00 \%$ & 862.065 & $100,00 \%$ \\
\hline
\end{tabular}

Fonte: Fenaseg. In homepage: www.fenaseg.org.br (1998). 
Observa-se que para os quatro anos analisados, a carteira do seguro RCTR-C foi, em média, $10 \%$ maior que a de Transportes Nacionais, variando essa diferença entre 4,36\%, no ano de 1997, e 15,85\%, no ano de 1994.

Essa informação, por si só, já seria suficiente para se afirmar que na maioria dos casos os transportadores rodoviários compram mais seguro para as mercadorias transportadas que os proprietários das mesmas, ou seja, mais que os embarcadores, que deveriam comprar os seguros de Transportes Nacionais ${ }^{19}$.

Considerando-se ainda que a carteira Transportes Nacionais engloba todos os outros modais de transporte - além do rodoviário, o ferroviário, o fluvial, o lacustre, o marítimo e o aéreo - fica mais evidente o fato de que os embarcadores - de uma maneira geral - não estão comprando o seguro de transporte rodoviário para suas mercadorias quando as entregam aos transportadores.

Na realidade, os Seguros de Transporte são mais utilizados para o transporte internacional de mercadorias. Essa informação também pode ser observada na Tabela 5.

O seguro de transporte intermodal ainda pode ser considerado insignificante no Brasil, perfazendo menos que $0,4 \%$ do total dos prêmios de seguro de transporte, percentual esse que reflete um prêmio anual pouco maior que $\mathrm{R} \$ 1$ milhão. Essa participação tende a aumentar, à medida que a concepção de cadeia logística for ganhando espaço na movimentação de cargas no País.

Analisando-se os seguros de responsabilidade de transportadores, percebe-se claramente a predominância dos seguros voltados ao transporte rodoviário: RCTR-C e RCF-DC. O primeiro responde por aproximadamente $20 \%$ dos prêmios totais dos seguros incluídos na classificação "Demais Ramos", sendo aquele de maior importância dentro dessa categoria. O RCF-DC também é bastante relevante, perfazendo em média $10 \%$ dos prêmios e passando a ser o segundo em importância na categoria a partir do ano de 1995.

\footnotetext{
${ }^{19}$ Uma ressalva deve ser feita: os embarcadores que utilizam seguro de transporte para suas cargas podem ser empresas de grupos multinacionais, sendo bastante comum tais empresas comprarem esse seguro nos seus países de origem, o que, obviamente, acaba não sendo computado nos prêmios recebidos por seguradoras nacionais.
} 
Esses dois seguros, juntos, movimentaram $\mathrm{R} \$ 290$ milhões no ano de 1997, o que representa $1,6 \%$ do total de prêmios produzidos pelo mercado segurador naquele ano.

Os outros seguros de responsabilidade civil de transportadores (RCA-C, RCTA-C e RCTR-VI), por sua vez, movimentam quantidades insignificantes de prêmios quando comparados com o RCTR-C e o RCF-DC, o que ratifica a importância do modal rodoviário no transporte de cargas no País.

Um outro enfoque dado à análise do mercado segurador é o da sinistralidade, ou seja, a razão entre Sinistro Retido (total das indenizações pagas pelas companhias seguradoras) e Prêmio Ganho. Para a presente análise, será convencionada a nomenclatura "Sinistralidade I" (S.I) para a razão entre Sinistro Retido e Prêmio Ganho, e "Sinistralidade II" (S.II) para a razão entre a soma do Sinistro Retido com as Despesas Comerciais, e Prêmio Ganho. A Tabela 6 ilustra as sinistralidades para os seguros de transporte e de responsabilidade de transportadores.

Tabela 6. Sinistralidades I e II para os seguros de transportes e para os de responsabilidade civil de transportadores.

\begin{tabular}{lcccccccc}
\hline \multirow{2}{*}{\multicolumn{1}{c}{ RAMO }} & \multicolumn{2}{c}{1994} & \multicolumn{2}{c}{1995} & \multicolumn{2}{c}{1996} & \multicolumn{2}{c}{1997} \\
\cline { 2 - 8 } & S.I & S.II & S.I & S.II & S.I & S.II & S.I & S.II \\
\hline Transp. Intermodal & $0,00 \%$ & $10,30 \%$ & $25,06 \%$ & $49,24 \%$ & $15,56 \%$ & $33,16 \%$ & $41,26 \%$ & $60,74 \%$ \\
Transp. Internacional & $36,06 \%$ & $57,97 \%$ & $30,61 \%$ & $51,21 \%$ & $32,70 \%$ & $52,65 \%$ & $38,89 \%$ & $60,15 \%$ \\
Transp. Nacional & $74,42 \%$ & $97,37 \%$ & $62,94 \%$ & $86,79 \%$ & $65,75 \%$ & $87,85 \%$ & $65,91 \%$ & $89,40 \%$ \\
RCTR-C & $48,49 \%$ & $68,45 \%$ & $45,82 \%$ & $63,53 \%$ & $54,63 \%$ & $73,30 \%$ & $55,44 \%$ & $75,06 \%$ \\
RCA-C & $12,47 \%$ & $23,84 \%$ & $1,14 \%$ & $14,34 \%$ & $15,35 \%$ & $25,97 \%$ & $17,76 \%$ & $15,71 \%$ \\
RCF-DC & $72,98 \%$ & $93,55 \%$ & $62,37 \%$ & $86,89 \%$ & $74,33 \%$ & $87,04 \%$ & $84,81 \%$ & $97,18 \%$ \\
RCTA-C & $0,00 \%$ & $0,00 \%$ & $6,96 \%$ & $25,74 \%$ & $51,98 \%$ & $64,87 \%$ & $65,27 \%$ & $105,31 \%$ \\
RCTR-VI & $0,00 \%$ & $12,83 \%$ & $7,85 \%$ & $11,76 \%$ & $11,13 \%$ & $18,60 \%$ & $9,00 \%$ & $18,01 \%$ \\
\hline
\end{tabular}

Fonte: elaborado com dados da Fenaseg. In homepage: www.fenaseg.org.br (1998).

O seguro RCF-DC foi aquele que apresentou a maior média de Sinistralidade I nos quatro anos analisados - 73,62\% - ficando o de Transportes Nacionais em segundo lugar, 
com uma média de $67,26 \%$. Analisando-se a Sinistralidade II, essa mesma tendência é verificada, com médias de $91,17 \%$ e $90,35 \%$, respectivamente.

Essa elevada sinistralidade do RCF-DC explica o desinteresse de várias empresas seguradoras em oferecer esse seguro aos transportadores, fruto da grande incidência de roubo ou desvio de cargas no País nos últimos anos. É bastante provável também que a sinistralidade alta do seguro de Transportes Nacionais também seja explicada - em parte pelo mesmo motivo, pois esse seguro objetiva cobrir o segurado-embarcador de eventos dessa natureza quando ficar comprovada a existência de um caso de força maior.

O seguro RCTR-C apresentou uma sinistralidade (S.I) média de 51\% nos anos analisados, portanto, bastante inferior à do seguro RCF-DC. Sendo assim, e contrariamente a esse último, parece não haver problemas de oferta de RCTR-C por parte das seguradoras. Além do mais, há a obrigatoriedade na compra desse seguro por parte dos transportadores, implicando, consequentemente, a obrigatoriedade de sua venda pelas companhias seguradoras.

A oferta dos seguros é outro ponto que merece consideração. O número de empresas que atuam no mercado e a sua percentagem no total de empresas, são apresentados resumidamente na Tabela 7 .

Tabela 7. Número de empresas e participação desse número no mercado dos seguros mencionados.

\begin{tabular}{ccccccc}
\hline Tipo de & \multicolumn{6}{c}{ Ano } \\
\cline { 2 - 7 } Seguro & \multicolumn{2}{c}{1994} & \multicolumn{2}{c}{1995} \\
\cline { 2 - 7 } & $\begin{array}{c}\mathrm{N}^{\circ} \text { de Empresas } \\
\text { Operadoras* }\end{array}$ & $\begin{array}{c}\text { Participação } \\
\text { no total }\end{array}$ & $\begin{array}{c}\mathrm{N}^{\circ} \text { de Empresas } \\
\text { Operadoras* }\end{array}$ & $\begin{array}{c}\text { Participaçã } \\
\text { no total }\end{array}$ & $\begin{array}{c}\mathrm{N}^{\circ} \text { de Empresas } \\
\text { Operadoras* }\end{array}$ & $\begin{array}{c}\text { Participação } \\
\text { no total }\end{array}$ \\
\cline { 2 - 7 } Transportes & 92 & $67 \%$ & 121 & $89 \%$ & 83 & $62 \%$ \\
Nacionais & 92 & 77 & $57 \%$ & 68 & $50 \%$ \\
RCTR-C & 75 & $55 \%$ & 58 & $42 \%$ & 48 & $35 \%$ \\
RCF-DC & 55 & $40 \%$ & $58 \%$ &
\end{tabular}

Fonte: Fenaseg. In homepage: www.fenaseg.org.br (1998).

$\left(^{*}\right)$ empresas que apresentaram Prêmio Total maior que zero. 
Primeiramente, observa-se os seguros de Transportes Nacionais são aqueles comercializados por um maior número de companhias. Em média, $72 \%$ das empresas comercializaram esse seguro entre 1994 e 1996.

No caso do RCTR-C, são em menor número as empresas que o comercializam, sendo que o percentual de companhias que atuam nesse mercado variou de $50 \%$ a $57 \%$ entre 1994 e 1996.

Finalmente, o seguro RCF-DC é aquele que conta com a atuação de um menor número de empresas, havendo aproximadamente $40 \%$ das companhias com alguma atuação nesse segmento.

Um dos motivos que explica essa diferença na oferta dos seguros é o fato de que os seguros de Transportes Nacionais contemplam vários modais. Consequentemente, caracterizam-se por uma maior diversidade de riscos e criando um número maior de segmentos específicos. Isso abre oportunidades para mais empresas, mesmo que, na média, a sinistralidade dessa carteira seja relativamente elevada.

No caso do RCF-DC, a sinistralidade elevada, decorrente da alta incidência de desvio ou roubo de carga, deve ser a principal razão para o baixo número de companhias atuando no segmento.

Para que esta análise fique mais fundamentada, é importante não só verificar o número de empresas atuando no setor, mas também a participação desses empresas no segmento específico. Para tanto, foi elaborada a Tabela 8, que apresenta a participação das quatro, oito e doze maiores empresas ( $\mathrm{C} 4, \mathrm{C} 8$ e $\mathrm{C} 12$, respectivamente), nos mercados específicos dos seguros em análise (considerando-se o volume de Prêmios Totais). 
Tabela 8. Índices de concentração das quatro, oito e doze maiores seguradoras, em três anos, para os mercados dos seguros mencionados.

\begin{tabular}{ccccccccccc}
\hline & \multicolumn{10}{c}{ Ano } \\
\cline { 2 - 10 } Tipo de Seguro & \multicolumn{3}{c}{1994} & \multicolumn{1}{c}{1995} & & & 1996 \\
& \cline { 2 - 10 } & C4 & C8 & C12 & C4 & C8 & C12 & C4 & C8 & C12 \\
\cline { 2 - 10 } & & & & & & & & & \\
\hline Transportes Nacionais & $33,5 \%$ & $55,9 \%$ & $66,0 \%$ & $31,1 \%$ & $51,8 \%$ & $62,9 \%$ & $27,1 \%$ & $48,5 \%$ & $59,0 \%$ \\
RCTR-C & $54,3 \%$ & $73,2 \%$ & $83,0 \%$ & $46,7 \%$ & $88,8 \%$ & $78,9 \%$ & $54,0 \%$ & $75,0 \%$ & $84,3 \%$ \\
RCF-DC & $75,2 \%$ & $87,0 \%$ & $92,7 \%$ & $71,9 \%$ & $85,3 \%$ & $92,9 \%$ & $74,4 \%$ & $86,2 \%$ & $91,9 \%$ \\
\hline
\end{tabular}

Fonte: Fenaseg. In homepage: www.fenaseg.org.br (1998).

Dado o menor número de empresas que operam com o seguro RCF-DC, era de se esperar que esse mercado fosse mais concentrado. Tal expectativa pode ser verificada a partir dos dados da Tabela 8, ao se comparar os tipos de seguro.

No ano de 1996, as quatro maiores empresas que comercializaram o RCF-DC foram responsáveis por $74 \%$ dos prêmios totais; já as quatro maiores, dentre aquelas que operavam com os seguros de Transportes Nacionais, foram responsáveis por apenas $27 \%$ dos prêmios totais produzidos. A concentração no mercado do RCTR-C, por sua vez, encontra-se em um patamar intermediário às dos outros dois seguros, apresentando um $\mathrm{C} 4$ igual a 54\% naquele mesmo ano de 1996.

Mais relevante ainda é a participação das doze maiores empresas (C12) no mercado do RCF-DC, que foram responsáveis por $92 \%$ dos prêmios em 1996, ou seja, apenas $9 \%$ das companhias de seguro movimentaram mais de $90 \%$ dos prêmios em 1996. Além disso, a maior empresa desse mercado apresentou uma participação de $47 \%$ no volume de prêmios totais, concentração esta bastante evidente e que pode causar alguns problemas no mercado considerado. 


\section{MATERIAL E MÉTODOS}

A pesquisa desenvolvida neste trabalho apresenta um caráter exploratório e descritivo. É exploratória pois tem como um dos objetivos principais o aprimoramento de idéias. É descritiva por empenhar-se em elaborar uma descrição das características de um determinado grupo de indivíduos - no caso as empresas transportadoras - e o estabelecimento de relações entre variáveis relacionadas a tais indivíduos (Gil, 1987).

O procedimento técnico utilizado é o levantamento, o qual consiste em uma "interrogação direta das pessoas cujo comportamento se deseja conhecer" (Gil, 1987, p.56).

Segundo esse mesmo autor, o levantamento apresenta vantagens e desvantagens. São exemplos das primeiras, o conhecimento direto da realidade, a economicidade e rapidez do processo e a possibilidade de quantificação das variáveis. Já as desvantagens podem ser exemplificadas pela ênfase nos aspectos perceptivos dos indivíduos (o que pode levar a erros), a pouca profundidade no estudo da estrutura e dos processos sociais, e a limitada apreensão no processo de mudança.

Acredita-se que a principal vantagem para a presente pesquisa seja $o$ conhecimento direto da realidade, e a principal desvantagem, a ênfase nos aspectos perceptivos do indivíduo. Aos indivíduos são colocadas situações nas quais deverão responder baseados em sua percepção, e como se sabe, tal percepção apresenta um caráter estritamente subjetivo. Ainda que essa desvantagem exista, acredita-se não haver formas de evitá-la.

Para a coleta de dados no levantamento, a técnica de interrogação utilizada é o questionário, enviado via correio.

É importante ressaltar, contudo, que várias entrevistas com indivíduos do mercado e especialistas no assunto também foram conduzidas, com o objetivo de obter informações detalhadas que não são captadas nos questionários, e que podem ser úteis no embasamento das informações. 
A amostra de empresas foi obtida através de sorteio, tendo como fonte de informações o banco de dados do Sistema de Informações de Fretes para Cargas Agrícolas $^{20}$ (SIFRECA).

O banco de dados do SIFRECA é composto por aproximadamente 20.000 empresas, principalmente transportadoras e agroindústrias, distribuidas em todo o território nacional.

Objetivando uma melhor representação da amostra no que se refere à distribuição geográfica das empresas transportadoras, dividiu-se o País em quatro grandes regiões: Norte/Nordeste, Centro-Oeste, Sudeste e Sul. De maneira a verificar essa distribuição, utilizou-se informações da Pesquisa Anual do Transporte Rodoviário (PATR), do IBGE. O sorteio, portanto, foi conduzido separadamente nos quatro grupos, conforme a distribuição das empresas apresentada na PATR. A Tabela 9 mostra o tamanho da amostra obtida conforme a região, e a distribuição das empresas segundo o IBGE.

Tabela 9. Tamanho da amostra e comparação com a PATR/IBGE.

\begin{tabular}{cccccc}
\hline \multirow{2}{*}{ Região } & \multicolumn{2}{c}{ Tamanho da Amostra } & \multicolumn{2}{c}{ PATR 1990* (IBGE) } \\
& $\begin{array}{c}\text { Número de } \\
\text { Empresas (A) }\end{array}$ & Participação & $\begin{array}{c}\text { Número de } \\
\text { Empresas (B) }\end{array}$ & Participação & (A)/(B) \\
\hline Norte/Nordeste & 157 & $19,6 \%$ & 1401 & $7,33 \%$ & $11,2 \%$ \\
Centro-Oeste & 90 & $11,3 \%$ & 644 & $3.37 \%$ & $14.0 \%$ \\
Sudeste & 244 & $30,5 \%$ & 9992 & $52,28 \%$ & $2,4 \%$ \\
Sul & 309 & $38,6 \%$ & 7075 & $37,02 \%$ & $4,4 \%$ \\
\hline TOTAL & 800 & $100,0 \%$ & 19112 & $100,00 \%$ & $4,2 \%$ \\
\hline
\end{tabular}

* Utilizou-se os dados de 1990 visto ser o último ano em que a PATR foi censitária.

A elaboração do questionário segue as recomendações de Selltiz et al. (1987) e Goode \& Hatt (1968). Dentre essas recomendações, as mais relevantes são a utilização

\footnotetext{
${ }^{20}$ O SIFRECA é um projeto de pesquisa desenvolvido pelo Departamento de Economia, Administração e Sociologia da Escola Superior de Agricultura "Luiz de Queiroz" (USP), que tem como objetivo principal, o levantamento periódico de informações de valores de fretes para cargas agrícolas e agroindustriais no Brasil, para os diferentes modais de transporte.
} 
de uma apelo, a opção pelo anonimato dos respondentes, a elaboração de questões "fechadas" (fixas) e a facilitação da devolução dos questionários.

O apelo diz respeito a uma carta de apresentação na qual se esclarece o objetivo da pesquisa, assim como o porquê e para quem a mesma está sendo elaborada, sempre atentando-se para o fato de que essa correspondência seja a mais sucinta possível. $\mathrm{O}$ apelo utilizado consta no Anexo.

O anonimato dos respondentes é algo bastante importante para esta pesquisa, principalmente pelo fato de que a aquisição de alguns seguros de transporte é obrigatória pela legislação, o que poderia influenciar na resposta dos indivíduos caso houvesse a necessidade de sua identificação.

Há ainda um outro aspecto importante. As empresas transportadoras, seja por motivação própria, seja por interesse dos embarcadores, preferem ocultar as ocorrências de roubo em sua frota de forma a não prejudicar a imagem da eficiência da empresa, bem como a imagem do produto que estava sendo transportado. Espera-se que com o anonimato seja eliminado esse tipo de problema.

A utilização de questões do tipo "fechada" facilita a análise dos dados, bem como a resposta por parte dos respondentes. Sendo assim, opta-se por esse tipo de questão, à exceção de algumas questões que permitem a inclusão de outras alternativas por parte dos entrevistados.

De forma a facilitar as devoluções dos questionários, foram anexados envelopes para respostas, endereçados aos pesquisadores, e devidamente selados. Esperou-se, com isso, aumentar as chances de recebimento dos questionários respondidos.

Para a elaboração do questionário foram entrevistadas, via telefone ou pessoalmente, 20 empresas de transporte de cargas localizadas no Estado de São Paulo. Além de objetivar a construção das questões e suas alternativas, esses contatos apresentam significativa importância no sentido de captar opiniões e anseios dos transportadores em relação ao assunto.

O questionário foi composto por 25 questões do tipo "fechada", à exceção das questões de número 2 e 25 , que se referem ao número de filiais e ao nome da corretora de seguros das empresas, respectivamente; e às questões 13 e 14, referentes às 
avaliações dos entrevistados sobre a eficiência dos seguros RCTR-C e RCF-DC. As questões de número 4 e 10 - referentes ao tipo de carga transportada e aos procedimentos de gerência de risco, respectivamente - permitiam ao entrevistado a inclusão de outras alternativas.

Para a elaboração do questionário, preocupou-se principalmente com a facilidade de sua resposta por parte dos entrevistados. Várias vezes, inclusive, preferiu-se perder no detalhamento da informação, visando obter um número razoável de respostas, que se constituirão na base empírica para a verificação das hipóteses formuladas.

Outra técnica utilizada para garantir um número satisfatório de questionários respondidos foi a adoção de um procedimento em que era estabelecido um contato telefônico prévio com as empresas, de forma a identificar a pessoa e/ou departamento responsável pela administração da carteira de seguros. Através desse contato, era explicado ao referido indivíduo o objetivo e importância da pesquisa, bem como era solicitado ao mesmo a resposta do questionário que seria enviado oportunamente.

Através desse procedimento, procurou-se dar maior confiabilidade à pesquisa e identificar, exatamente, o indivíduo responsável pelo seguro e também a filial da empresa onde fica concentrada essa administração, quando fosse o caso ${ }^{21}$. Deve-se estar ciente, contudo, que tal procedimento pode incorrer em um certo viés na amostra.

\subsection{Descrição das Variáveis}

A Tabela 10 apresenta as variáveis que são utilizadas no trabalho, sua respectiva sigla, o número da questão correspondente no questionário e o número de alternativas possíveis.

\footnotetext{
${ }^{21}$ A existência de várias filiais de uma mesma empresa é uma característica bastante comum no setor; por isso, a importância de se identificar aquela onde são tomadas as decisões em relação à compra de seguros de transporte.
} 
Tabela 10. Descrição das variáveis da pesquisa.

\begin{tabular}{|c|c|c|c|}
\hline Variável & Sigla & Questão & $\mathrm{N}^{\mathrm{o}}$ Alternativas \\
\hline Tipo de Estabelecimento & ESTABEL & 1 & 2 \\
\hline Número de Filiais da Empresa & FILLAL & 2 & I \\
\hline Localização Geográfica & $L O C A L G$ & - & 26 \\
\hline Classificação da Empresa & CLASSE & 3 & 3 \\
\hline Tipo de Carga & $T C A R G A$ & 4 & $9^{*}$ \\
\hline Tempo de Atividade & $F U N D A C ̧$ & 5 & 6 \\
\hline Tamanho da Frota & TFROTA & 6 & 10 \\
\hline Idade da Frota & IFROTA & 7 & 6 \\
\hline Condição Financeira & FINANC & 8 & 3 \\
\hline Experiência com Roubo de Carga & NROUBO & 9 & 10 \\
\hline Procedimentos de Gerência de Risco & PROCED & 10 & $6^{*}$ \\
\hline Especialização na administração dos seguros & ESPSEG & 11 & 2 \\
\hline Opinião sobre a administração dos seguros & ADMSEG & 12 & 4 \\
\hline Nota para o RCTR-C & NOTRCT & 13 & I \\
\hline Nota para o RCF-DC & NOTRCF & 14 & I \\
\hline Problema com Oferta do RCF-DC & OFERCF & 15 & 4 \\
\hline Opinião a respeito do Preço do RCTR-C & $\$ R C T R C$ & 16 & 3 \\
\hline Opinião a respeito do Preço do RCF-DC & $\$ R C F D C$ & 17 & 3 \\
\hline Exigência do Embarcador para o RCTR-C & EXIRCT & 18 & 3 \\
\hline Exigência do Embarcador para o RCF-DC & EXIRCF & 19 & 3 \\
\hline Comportamento do Embarcador para o RR & $C O M P R R$ & 20 & 4 \\
\hline Freqüência para a compra do RCTR-C & FRERCT & 21 & 6 \\
\hline Valor Mínimo para o RCTR-C & MINRCT & 22 & 6 \\
\hline Freqüência para a compra do RCF-DC & $F R E R C F$ & 23 & 6 \\
\hline Valor Mínimo para o RCF-DC & $M I N R C F$ & 24 & 6 \\
\hline Serviço prestado pela corretora de seguros & SERVCO & 25 & 4 \\
\hline
\end{tabular}

A seguir são feitas algumas considerações sobre essas variáveis e o seu objetivo no contexto da pesquisa. Além disso, é comentada a forma como as variáveis são mensuradas a partir das respostas dos questionários. 


\section{Tipo de Estabelecimento (ESTABEL):}

Geralmente, a administração da carteira de seguros de uma empresa de transporte está concentrada na sua matriz. Quando do sorteio da amostra, procurou-se selecionar apenas matrizes de empresas; todavia, em muitos casos, não se tinha a informação de que aquele estabelecimento sorteado seria a matriz ou uma filial. Sendo assim, criou-se a variável ESTABEL para captar esse efeito. Portanto, precauções são tomadas quando um questionário é respondido por um indivíduo de uma filial. Em algumas situações, poderá ser necessária a exclusão desses casos, para não comprometer a qualidade das informações. A Tabela 11 apresenta a descrição da variável ESTABEL.

Tabela 11. Descrição da variável ESTABEL.

\begin{tabular}{cc}
\hline Questão 1: "Este estabelecimento de transporte é:" & \\
\hline Alternativas propostas & Representação para ESTABEL \\
\hline Matriz da empresa & $\mathrm{M}$ \\
Filial da empresa & $\mathrm{F}$ \\
\hline
\end{tabular}

\section{Número de Filiais da Empresa (FILIAL):}

Juntamente com a variável "Tamanho da Frota", a ser comentada a seguir, a variável "Número de Filiais" serve como uma indicação do porte da empresa: se grande, média ou pequena.

Essa variável é obtida através da segunda questão do questionário. É uma das únicas questões do tipo "aberta", de fácil resposta por parte do entrevistado, no caso, um número real inteiro.

\section{Localização Geográfica (LOCALG):}

Esta variável apresenta o objetivo básico de permitir o estudo da relação entre a localização geográfica de determinada empresa com o roubo de carga e a utilização de seguro. Essa análise é de fundamental importância, vista a maior concentração de ocorrências - principalmente o roubo de cargas - em algumas regiões do País. 
A variável $L O C A L G$ foi obtida através da leitura do carimbo do posto do correio de onde o questionário foi reenviado aos pesquisadores.

\section{Classificação da Empresa (CLASSE):}

Trata-se de uma variável com o objetivo de classificar os transportadores conforme a sua atividade.

A Lei Federal N ${ }^{\circ} 7.092$, de 19 de abril de 1983, criou o Registro Nacional de Transportadores Rodoviários de Bens (RTB) e fixou as condições para o exercício da atividade. Essa lei foi regulamentada pelo Decreto $N^{\circ} 89.874$, de 28 de junho de 1984 .

Esse aparato legal dividiu os transportadores em três grandes categorias: "Empresa de Transporte Comercial" (ETC), "Transportador Comercial Autônomo" (TCA) e o "Transportador de Carga Própria" (TCP). Recentemente, essa regulamentação vem passando por uma série de alterações. Todavia, é uma classificação bastante interessante, tendo sido adotada nesta pesquisa, com algumas pequenas mudanças na sua nomenclatura.

Isso posto, foram consideradas três categorias, mais simplificadas e de fácil entendimento. São elas: "Empresa de Transporte de Cargas de Terceiros" (ETC), em substituição ao termo "Empresa de Transporte Comercial"; "Empresa que Transporta Carga Própria" (TCP), em substituição ao termo "Transportador de Carga Própria"; e simplesmente "Transportador Autônomo" (TA), em substituição a "Transportador Comercial Autônomo".

Entende-se por ETC uma empresa cuja atividade econômica é a prestação de serviço de transporte para outras empresas ou indivíduos. É comum ocorrerem casos em que a empresa também tenha outra atividade, como por exemplo, uma representação comercial. Contudo, o transporte de cargas continua sendo sua principal atividade.

É considerada uma TCP aquela empresa cuja atividade econômica principal não é a de transporte; porém, essa empresa possui (ou arrenda) veículos responsáveis pela movimentação de sua própria carga.

Finalmente, TA é o caso em que um indivíduo transportador (pessoa física) presta serviço de transporte a terceiros mediante remuneração. 
Neste estudo objetiva-se principalmente o entendimento do comportamento das ETCs. Porém, em muitos casos, não se tinha o conhecimento de que determinada empresa sorteada para a amostra seria ou não uma ETC. A inclusão da variável CLASSE serve como uma forma de separar essas classes ou categorias.

A Tabela 12 apresenta a descrição da variável CLASSE.

Tabela 12. Descrição da variável CLASSE.

\begin{tabular}{cc}
\hline Questão 3: “Assinale a classificação de sua atividade:" \\
\hline Alternativas propostas & Representação para CLASSE \\
\hline Empresa de Transporte de Carga de Terceiros & ETC \\
Empresa que Transporta Carga Própria & TCP \\
Transportador Autônomo & TA \\
\hline
\end{tabular}

\section{Tipo de Carga (TCARGA):}

O conhecimento do tipo de carga operado pelos transportadores é de suma importância no contexto, vista a relação entre a ocorrência de sinistros e o grau de especificidade do ativo "carga".

A questão referente a essa variável é a de número 4 do questionário. Assim como a questão 2 , esta é uma questão que admite uma resposta alternativa àquelas oferecidas ao entrevistado.

A Tabela 13 apresenta a descrição da variável TCARGA.

Tabela 13. Descrição da variável TCARGA.

\begin{tabular}{cc}
\hline Questão 4: "Assinale o tipo de carga mais transportada pela sua empresa" \\
\hline Alternativas propostas & Representação para TCARGA \\
\hline carga seca & $\mathrm{CS}$ \\
granéis sólidos & $\mathrm{GS}$ \\
carga viva & $\mathrm{CV}$ \\
granéis líquidos & $\mathrm{GL}$ \\
carga refrigerada & $\mathrm{CR}$ \\
automóveis & $\mathrm{AU}$ \\
contêiner & $\mathrm{CT}$ \\
bebidas & $\mathrm{BE}$ \\
outras & (aberto) \\
\hline
\end{tabular}




\section{Tempo de Atividade (FUNDAÇ):}

Procura-se, com a inclusão desta variável, uma proxy para a experiência da empresa no mercado. A Tabela 14 apresenta a descrição da variável FUNDAÇ.

Tabela 14. Descrição da variável $F U N D A C ̧$.

\begin{tabular}{cc}
\hline Questão 5: "Sua empresa foi fundada há:" & \\
\hline Alternativas propostas & Valores assumidos por $F U N D A C \zeta$ \\
\hline menos de 5 anos & 3 \\
entre 5 e 10 anos & 7 \\
entre 11 e 15 anos & 13 \\
entre 16 e 20 anos & 18 \\
entre 21 e 25 anos & 23 \\
mais de 25 anos & 27 \\
\hline
\end{tabular}

Alguns comentários sobre as características dessa e de outras variáveis utilizadas neste estudo (tais como a TFROTA, a IFROTA e a NROUBO), se fazem necessários.

Segundo Hoffmann (1991), seria conveniente que os intervalos de classe tivessem a mesma magnitude. Isso porém, continua o autor, não é algo obrigatório. No caso desta pesquisa, por exemplo, a natureza pouco conhecida das variáveis dificultou a estipulação de intervalos de mesma magnitude, bem como limites bem definidos. Foram assim adotados valores intermediários desses intervalos para as análises econométricas ${ }^{22}$.

Conforme Hoffmann et al. (1986), há sempre que se adotar pressuposições a respeito da distribuição intra-estratos. Tais autores, ao estudarem a distribuição de renda no Brasil, admitiram funções de densidade linear dentro dos estratos, à exceção do estrato aberto à direita, cuja desigualdade foi estimada com uma função de Pareto.

Isso posto, e considerando que as variáveis utilizadas neste trabalho apresentam distribuições de probabilidade, de certa forma, desconhecidas, admite-se uma distribuição linear dentro dos intervalos, sendo adotado o valor central para efeitos de utilização nos modelos econométricos. Para os intervalos abertos adotou-se o valor do seu limite inferior, acrescido de uma quantidade correspondente à diferença aproximada

\footnotetext{
${ }^{22}$ A forma com que as informações foram levantadas junto às empresas, através de alternativas tipo intervalo, pode implicar limitações quanto à precisão dos dados.
} 
entre os valores assumidos pelas alternativas anteriores (ou posteriores, para intervalos abertos à esquerda).

\section{Tamanho da Frota (TFROTA):}

O objetivo principal da variável TFROTA é a captação de uma indicação referente ao tamanho da empresa. Certamente, essa informação por si só pode não representar um significado muito preciso, pois não considera fatores tais como o endividamento da empresa. Outros artifícios serão utilizados para tentar verificar esses aspectos, como por exemplo, a inclusão da variável FINANC, que será comentada a seguir.

De qualquer maneıra, é uma variável que será bastante utilizada durante as análises. A Tabela 15 apresenta a descrição da variável TFROTA.

Tabela 15. Descrição da variável TFROTA.

Questão 6: "Qual o número aproximado de caminhões de sua empresa (incluindo agregados)?"

\begin{tabular}{cc}
\hline Alternativas propostas & Valores assumidos por TFROTA \\
\hline menos de 4 & 3 \\
entre 4 e 10 & 6 \\
entre 11 e 20 & 15 \\
entre 21 e 50 55 \\
entre 51 e 100 & 35 \\
entre 101 e 200 & 150 \\
entre 201 e 300 & 350 \\
entre 301 e 400 & 250 \\
entre 401 e 500 & 450 \\
mais de 500 & 550 \\
\hline
\end{tabular}

\section{Idade da Frota (IFROTA):}

Considerada juntamente com a TFROTA, a variável IFROTA fornece uma indicação do tamanho da empresa, ou melhor, da situação de seu patrimônio. A Tabela 16 apresenta a descrição da variável IFROTA. 
Tabela 16. Descrição da variável IFROTA.

\begin{tabular}{cc}
\hline Questão 7: “Qual a idade média dos caminhões de sua empresa (incluindo agregados)?” \\
\hline Alternativas propostas & Valores assumidos por IFROTA \\
\hline menos de 2 anos & 1 \\
entre 2 e 4 anos & 3 \\
entre 5 e 7 anos & 6 \\
entre 8 e 10 anos & 9 \\
entre 11 e 13 anos & 12 \\
mais de 13 anos & 14 \\
\hline
\end{tabular}

\section{Condição Financeira (FINANC):}

Como mencionado anteriormente, esta variável procura fornecer informações sobre a saúde financeira da empresa. Talvez esta seja a informação mais dificil de ser obtida dos entrevistados. Primeiro, porque muitas vezes o indivíduo encarregado da administração dos seguros não possui tal conhecimento. Segundo, porque a experiência acadêmica tem comprovado que geralmente os entrevistados superestimam respostas dessa natureza. Terceiro e último, porque é uma tarefa complicada resumir, em uma questão, alternativas capazes de captar efetivamente a realidade e, ao mesmo tempo, serem de fácil resposta por parte do entrevistado. A Tabela 17 apresenta a descrição da variável FINANC.

Tabela 17. Descrição da variável FINANC.

Questão 8: "Em relação à 'saúde financeira' de sua atividade de transporte, no ano passado ela:"

\begin{tabular}{cc}
\hline Alternativas propostas & Representação para FINANC \\
\hline fechou "no vermelho" & $\mathrm{V}$ \\
praticamente empatou os custos com as receitas & $\mathrm{E}$ \\
obteve lucro líquido & $\mathrm{L}$ \\
\hline
\end{tabular}

\section{Experiência com Roubo de Carga (NROUBO):}

Esta é a variável chave para relacionamentos entre a ocorrência de roubo de carga e as demais variáveis relevantes. Seguindo a idéia das questões anteriores, a 
questão que capta o $N R O U B O$ oferece alternativas que facilitam a resposta do entrevistado. A concepção de "roubo" neste caso - e durante toda a discussão dos resultados - sugere aqueles casos em que ocorre a posse indevida de parte ou totalidade da carga, com ou sem o desaparecimento concomitante do veículo transportador.

A Tabela 18 apresenta a descrição da variável NROUBO.

Tabela 18. Descrição da variável $N R O U B O$.

\begin{tabular}{cc}
\hline Questão 9: “Quantas vezes sua empresa já teve uma carga roubada nos últimos 5 anos?" \\
\hline Alternativas propostas & Valores assumidos por NROUBO \\
\hline nenhuma vez & 0 \\
1 vez & 1 \\
2 vezes & 2 \\
3 vezes & 3 \\
4 vezes & 4 \\
5 vezes & 5 \\
entre 6 e 10 vezes & 8 \\
entre 11 e 20 vezes & 15 \\
entre 21 e 30 vezes & 25 \\
mais de 30 vezes & 33 \\
\hline
\end{tabular}

\section{Procedimentos de Gerência de Risco (PROCED):}

A variável $P R O C E D$ refere-se à adoção dos diferentes procedimentos de Gerência de Risco por parte das empresas. O principal objetivo da mesma é analisar a relação de complementaridade e substitutibilidade entre o procedimento "seguro de carga" e as demais ferramentas utilizadas para gerenciar os riscos da atividade.

Além disso, tal variável permite a quantificação da importância dos diferentes procedimentos, dadas as características intrínsecas de cada grupo de empresas.

A Tabela 19 apresenta a descrição da variável PROCED. 
Tabela 19. Descrição da variável PROCED.

Questão 10: "Enumere em ordem de importância, os procedimentos de gerência de risco adotados por sua empresa para tratar o risco de roubo de cargas"

\begin{tabular}{cc}
\hline Alternativas propostas & Representação para $P R O C E D\left(^{*}\right)$ \\
\hline fazer um seguro da carga & segur \\
fracionar a carga em volumes menores & frac \\
utilizar escolta para a frota & escol \\
treinar motoristas para evitar o roubo de cargas & trein \\
equipar os veículos com rastreadores & rastr \\
não transportar cargas de valor elevado & nttransp \\
outro & (aberto) \\
\hline
\end{tabular}

(*) Essas variáveis assumirão um valor de 1 a 6 conforme sua ordem de importância. (Exemplo: caso o seguro seja considerado o procedimento mais importante: segur $=1$ ).

\section{Especia lização na Administração de Seguros (ESPSEG):}

A principal função desta variável é relacionar a demanda por seguro com a especialização na administração desse serviço dentro da empresa. Sendo assim, pode assumir dois valores: i) casos em que a administração dos seguros está sob a responsabilidade de uma pessoa e/ou departamento específico para o assunto; e ii) quando não há essa especialização, ou seja, quando os seguros são administrados por qualquer indivíduo da empresa (geralmente, um de seus administradores), ou o seu contador, por exemplo.

A Tabela 20 apresenta a descrição da variável ESPSEG.

Tabela 20. Descrição da variável ESPESG.

Questão 11: "Na sua empresa, quem é o responsável pela administração da carteira de seguro de carga?"

\begin{tabular}{lc}
\hline \multicolumn{1}{c}{ Alternativas propostas } & Representação para ESPSEG \\
\hline - há um Departamento de Seguro ou & $\mathrm{S}$ \\
pessoa exclusiva para executar essa & \\
tarefa & $\mathrm{N}$ \\
não há uma pessoa que trabalhe & \\
exclusivamente com seguro &
\end{tabular}




\section{Opiniāo sobre a Administração de Seguros (ADMSEG):}

O próprio nome desta variável explica o seu objetivo. Na realidade, a mesma procura identificar a impressão dos indivíduos em relação à operacionalização dos seguros de carga. Duas impressões procuram ser captadas pela ADMSEG: a "dificuldade" e a "burocracia" envolvidas na administração de uma carteira de seguros. A Tabela 21 apresenta a descrição da variável $A D M S E G$.

Tabela 21. Descrição da variável $A D M S E G$.

\begin{tabular}{cc}
\hline Questão 12: “Como você classifica a administração da carteira de seguros de carga?" \\
\hline Alternativas propostas & Representação para $A D M S E G$ \\
\hline fácil e não burocrática & 4 \\
fácil, porém burocrática & 3 \\
difícil, porém não burocrática & 2 \\
difícil e burocrática & 1 \\
\hline
\end{tabular}

Nota para o RCTR-C (NOTRCT) e para o RCF-DC (NOTRCF):

As variáveis NOTRCT e NOTRCF objetivam captar a impressão dos transportadores em relação à eficiência dos respectivos seguros de carga. Essas informações são obtidas através das questões 13 e 14, onde o entrevistado deve fornecer um conceito variando de 0 a 10, conforme sua avaliação.

A Tabela 22 apresenta a descrição das variáveis NOTRCT e NOTRCF.

Tabela 22. Descrição das variáveis NOTRCT e NOTRCF.

Questões 13 e 14: "Que nota, de 0 a 10 , você daria para a eficiência do Seguro de Responsabilidade Civil do Transportador Rodoviário de Carga (ou Seguro de Responsabilidade Civil do Transportador Rodoviário por Desvio de Carga), RCTR-C (ou RCF-DC), também chamado de seguro de tombamento (ou Seguro de roubo)?"

Alternativas propostas Valores assumidos por NOTRCT (ou NOTRCF) Resposta aberta $=\{$ números reais inteiros entre 0 e 10$\}$ 


\section{Problema com a Oferta do RCF-DC (OFERCF):}

Esta variável procura identificar as empresas que passam por alguma dificuldade no momento de adquirirem o seguro RCF-DC. A Tabela 23 apresenta a descrição da variável $O F E R C F$.

Tabela 23. Descrição da variável $O F E R C F$.

Questões 15: “Alguma vez uma corretora de seguro se negou a vender um seguro RCF-DC para sua empresa?"

\begin{tabular}{cc}
\hline Alternativas propostas & Representação para OFERCF \\
\hline não, nunca & 4 \\
sim, pelo menos uma vez & 3 \\
sim, várias vezes & 2 \\
sim, sempre & 1 \\
\hline
\end{tabular}

Opinião a Respeito do Preço do RCTR-C (\$RCTRC) e do RCF-DC (\$RCFDC):

O objetivo dessas variáveis é conhecer a impressão dos transportadores em relação aos valores de prêmios cobrados pelos respectivos seguros, mais especificamente em termos da relação custo/benefício dos seguros de transporte, e não exatamente, de uma avaliação do valor absoluto dos prêmios.

A Tabela 24 apresenta a descrição das variáveis $\$ R C T R C$ e $\$ R C F D C$.

Tabela 24. Descrição das variáveis $\$ R C T R C$ e $\$ R C F D C$.

Questões 16 e 17: "O que você acha do preço do Seguro de carga RCTR-C (ou RCFDC)?"

\begin{tabular}{cc}
\hline Alternativas propostas & Representação para \$RCTRC (ou \$RCFDC) \\
\hline baixo & 3 \\
ideal & 2 \\
alto & 1 \\
\hline
\end{tabular}




\section{Exigência do Embarcador para o RCTR-C (EXIRCT) e para o RCF-DC (EXIRCF-DC):}

As variáveis EXIRCT e EXIRCF procuram captar o efeito das exigências do embarcador na tomada de decisão em relação à compra de seguros por parte dos transportadores. A Tabela 25 apresenta a descrição das variáveis EXIRCT e EXIRCF.

Tabela 25. Descrição das variáveis EXIRCT e EXIRCF.

Questões 18 e 19: "O embarcador exige que sua empresa faça Seguro de carga RCTRC (ou RCF-DC)?"

\begin{tabular}{cc}
\hline Alternativas propostas & Representação para EXIRCT (ou EXIRCF) \\
\hline não exige & 3 \\
exige algumas vezes & 2 \\
sempre exige & 1 \\
\hline
\end{tabular}

Comportamento do Embarcador em Relação ao Seguro de Transporte (RR) (COMPRR):

O objetivo desta variável é captar mais um aspecto da relação entre transportadores e embarcadores em assuntos relacionados à demanda por seguro de carga: o comportamento do embarcador em relação ao Seguro de Transporte RR (o "seguro do embarcador").

A Tabela 26 apresenta a descrição da variável COMPRR.

Tabela 26. Descrição da variável COMPRR.

Questão 20: "Em relação ao Seguro RR, o seguro de Riscos Rodoviários, também chamado de 'seguro do embarcador', responda:"

Alternativas propostas

- embarcador exige que sua empresa faça esse seguro RR em nome do próprio embarcador

- embarcador faz esse seguro RR quando entrega a carga para sua empresa transportar

- embarcador não exige, nem faz esse seguro

- não sabe responder a esta questão. 


\begin{abstract}
Frequência para a Compra do RCTR-C (FRERCT) e do RCF-DC (FRERCF):

Essas são as variáveis ma1s importantes do trabalho, pois identificam a frequência com que os transportadores demandam os referidos seguros. A Tabela 27 apresenta a descrição das variáveis $F R E R C T$ e $F R E R C F$.
\end{abstract}

Tabela 27. Descrição das variáveis FRERCT e FRERCF.

Questões 21 e 23: "De uma maneira geral, sua empresa faz seguro de carga RCTR-C (ou RCF-DC) (averba a carga à seguradora):"

\begin{tabular}{cc}
\hline Alternativas propostas & Valores assumidos por FRERCT (ou FRERCF) \\
\hline nunca faz o seguro RCTR-C & 0 \\
em 20\% dos fretes praticados & 20 \\
em 40\% dos fretes praticados & 40 \\
em 60\% dos fretes praticados & 60 \\
em 80\% dos fretes praticados & 80 \\
em todos os fretes praticados & 100 \\
\hline
\end{tabular}

Valor Mínimo para a Compra do RCTR-C (MINRCT) e do RCF-DC (MINRCF):

Assim como as variáveis de frequência, citadas anteriormente, as variáveis MINRCT e MINRCF estão relacionadas diretamente à demanda dos seguros. São, portanto, complementares às primeiras, visto identificarem o comportamento dos transportadores em relação ao risco da atividade, traduzido pelo valor das cargas a serem transportadas.

A Tabela 28 apresenta a descrição das variáveis MINRCT e MINRCF. 
Tabela 28. Descrição das variáveis $M I N R C T$ e $M I N R C F$.

Questões 22 e 24: "Caso a sua empresa não faça (não averbe) seguro de carga RCTR$\mathrm{C}$ (ou RCF-DC) para todos os fretes, a partir de qual valor de carga, ela faz esse seguro:"

\begin{tabular}{cc}
\hline Alternativas propostas & Valores assumidos \\
\hline $\mathrm{R} \$ 2.000,00$ & 2 \\
$\mathrm{R} \$ 5.000,00$ & 5 \\
$\mathrm{R} \$ 10.000,00$ & 10 \\
$\mathrm{R} \$ 15.000,00$ & 15 \\
$\mathrm{R} \$ 20.000,00$ & 20 \\
$\mathrm{R} \$ 30.000,00$ & 30 \\
$\mathrm{R} \$ 50.000,00$ & 50 \\
$\mathrm{R} \$ 100.000,00$ & 100 \\
$\mathrm{R} \$ 200.000,00$ & 200 \\
\hline
\end{tabular}

\section{Serviço Prestado pela Corretora de Seguros (SERVCO):}

É uma variável utilizada para captação da impressão dos transportadores, nos mesmos moldes das variáveis NOTRCT e NOTRCF. A SERVCO, porém, é uma avaliação do serviço prestado pelos corretores de seguros, que são os agentes responsáveis pela comercialização desses produtos.

A última questão do questionário - a de número 25 - é aquela referente a essa variável. Nessa questão também existe uma campo onde os indivíduos devem responder o nome da corretora de seguros com a qual trabalham. Logo, é uma questão com duas partes: uma "fechada" e outra "aberta".

A Tabela 29 apresenta a descrição da variável SERVCO.

Tabela 29. Descrição da variável SERVCO.

Questão 25: "Qual o nome de sua corretora de seguros de carga? Como você avalia o serviço prestado por esta empresa?"

\begin{tabular}{|c|c|}
\hline Alternativas propostas & Representação para $S E R V C O$ \\
\hline Primeira parte: Resposta Aberta & $=$ nome da corretora de seguros \\
\hline Segunda parte: ruim & 1 \\
\hline razoável & 2 \\
\hline bom & 3 \\
\hline ótimo & 4 \\
\hline
\end{tabular}




\subsection{Análise do comportamento das empresas de transporte como consumidoras de seguro de carga}

A decisão pela compra ou não de um seguro é uma questão de maximização de utilidade sob condição de incerteza. Um referencial teórico importante nesse campo diz respeito à obra de von Neumann \& Morgenstern (1953).

Dentre as contribuições daquela obra, destaca-se a elaboração da denominada "Função Utilidade de von Neumann-Morgenstern" ou "Função de Utilidade Esperada", a qual é a base para um amplo leque de estudos de demanda sob condição de incerteza, inclusive demanda por seguros.

Ehrlich \& Becker (1972) utilizam a Função Utilidade de von NeumannMorgenstern para desenvolver uma teoria por demanda de seguros, a qual enfatizava a interação entre o seguro, self-insurance e self-protection ${ }^{23}$. Esse referencial teórico apresenta utilidade para o presente estudo, uma vez que algumas características a respeito desses três mecanismos de gerência de risco são analisadas empiricamente.

A maioria dos trabalhos referentes à demanda por seguros dizem respeito ao seguro de saúde. Neste sentido, deve ser mencionado o importante trabalho de Arrow ${ }^{24}$ (1963), o qual serve como um marco para tais estudos.

Friedman (1974) utiliza a teoria da maximização da utilidade esperada de von Neumann-Morgenstern para inferir sobre a a versão ao risco de indivíduos e famílias por problemas de saúde.

Evans \& Viscusi (1991), também trabalhando com incerteza em relação à saúde, elaboram uma análise que consiste no levantamento do valor que os indivíduos estariam dispostos a pagar para diminuir o risco de morbidades de dois produtos fictícios. Esse trabalho apresenta um aspecto importante, que é a simulação de situações possíveis, com

\footnotetext{
${ }^{23}$ Esses termos são traduzidos, muitas vezes, para "auto-seguro" e "auto-proteção", respectivamente. Optou-se pela utilização dos termos originais para evitar possíveis contradições conceituais.

${ }^{24}$ ARROW, K.J. Uncertainty and The Welfare Economics of Medical Care. The American Economic Review, v.53, n.5, p.941-973, Dec. 1963.
} 
o objetivo de analisar a reação dos indivíduos frente ao risco. Este tipo de pesquisa é genericamente denominado de "experimentos de laboratório" (laboratory experiments).

Marquis \& Holmer (1996) comparam um modelo padrão de utilidade esperada com modelos alternativos em relação à avaliação dos indivíduos sobre o risco de problemas de saúde. Contrariamente a Evans e Viscusi (1991) - que se utilizaram de um experimento - estes autores trabalharam com dados reais de planos de saúde de indivíduos, o que, segundo eles, apresenta uma certa vantagem.

Estudos sobre a demanda por outros tipos de seguros também foram encontrados na literatura. São exemplos desses: Attanasi \& Karlinger (1979) e Cicchetti \& Dubin (1994).

Attanasi \& Karlinger utilizam dados de apólices de seguros contra enchente nos Estados Unidos para estimar a aversão dos indivíduos a esse risco. No seu trabalho os autores chamam a atenção para o fato de que os indivíduos apresentam uma certa dificuldade ao tratar o risco de desastres naturais, pois ao mesmo tempo em que originam perdas severas, ocorrem com uma frequência relativamente baixa.

O trabalho de Cicchetti \& Dubin (1994) também utiliza a função de utilidade de von Neumann-Morgenstern, porém para uma pesquisa sobre a decisão de comprar ou não um seguro contra problemas em linhas telefônicas. Utilizando dados de proprietários de linhas telefônicas, os autores estimaram o formato da função de utilidade e o grau de aversão dos indivíduos àquele tipo de risco.

O que se percebe é que trabalhos sobre a decisão de compra de um determinado tipo de seguro utilizam, em linhas gerais, contratos de seguro que são relativamente homogêneos, ou seja, um padrão de seguro para todos os indivíduos, por prazo bem determinado, ou então valores homogêneos de prêmios.

O seguro de transporte (mais especificamente o de carga), por sua vez, não apresenta-se assim tão simples. Via de regra esses seguros são estabelecidos por um contrato aberto, ou seja, cada frete praticado pelo transportador não exige a elaboração de um contrato específico. O que ocorre são averbações, ou seja, apenas uma comunicação do segurado à seguradora. Além do mais, os prêmios variam em uma série 
de aspectos, tais como: valor da carga, tipo de carga, distância percorrida, local de origem e destino da carga, etc.

Considerando-se ainda a existência de uma ampla variedade de cargas, assım como de rotas, é de se esperar uma certa dificuldade de estruturação de problemas de análise de decisão quanto à aquisição desse tipo de seguro.

Outro fator a ser considerado diz respeito à disponibilidade de dados para a elaboração de análises de demanda por seguro. Não há dados disponíveis no Brasil referentes à utilização de seguros de carga por transportadores rodoviários.

Seria possível, talvez, a opção por estudos de caso utilizando apólices e averbações realizadas por determinadas empresas. Todavia, o fato de que alguns desses seguros são obrigatórios por parte da legislação, seria provável que houvesse dificuldade de acesso aos casos em que os seguros não são utilizados. A obtenção dessa informação de "não-seguro", inclusive, é um dos principais objetivos do trabalho.

Operacionalmente, a análise do comportamento das empresas como consumidores de seguro de carga (demanda por seguro), foi realizada de duas formas neste estudo:

i) com a utilização de técnicas de Estatística Descritiva e Não-Paramétrica;

ii) através dos chamados "modelos de resposta qualitativa" (qualitative response models), também denominados de modelos de escolha discreta.

Os modelos de escolha discreta são os mais indicados para análise de demanda por bens quando o objetivo é estudar a influência de características qualitativas dos indivíduos e de suas escolhas.

Há uma série de exigências para a adequada aplicação dos modelos de escolha discreta. Uma exigência fundamental está relacionada aos dados, que devem ser completos e bastante detalhados para que os devidos efeitos das variáveis possam ser captados pelos modelos econométricos.

$\mathrm{Na}$ utilização desses modelos para os estudos de demanda por seguros citados anteriormente, fica evidente que os pesquisadores dispunham de séries completas e detalhadas de dados. 
No trabalho aqui realizado, os dados são obtidos através de questionários aplicados diretamente aos indivíduos e, para tanto, as questões são construídas de forma a facilitar as respostas, o que obviamente, acaba gerando uma certa perda no detalhamento da informação. Por exemplo, é questionado aos indivíduos o número médio de caminhões da frota de sua empresa. Seria interessante que essa informação fosse fornecida com exatidão; porém, muitas vezes e, principalmente nas médias e grandes empresas, os indivíduos - inclusive aquele responsável pela compra de seguros não detêm esse conhecimento exato, o que faria com que essa questão não fosse respondida. Por outro lado, se ao respondente forem apresentadas alternativas do tipo "entre 4 e 10 caminhões", isso possibilitaria a sua resposta ${ }^{25}$.

Vistas as limitações do modelo e a característica da atividade de transporte, uma alternativa para melhor fundamentar a análise dos dados foi a utilização de técnicas de Estatística Descritiva e de Estatística Não-Paramétrica, não tão avançadas como os modelos econométricos mencionados, mas bastante flexíveis, portanto, úteis para o propósito deste trabalho. Um modelo de resposta qualitativa também foi utilizado para o estudo de demanda por seguro de carga, o que possibilitou a confrontação dos resultados obtidos com as análises estatísticas.

\subsubsection{Técnicas de Estatística Descritiva e Não-Paramétrica}

Uma forma adotada para a análise dos resultados foi a comparação das médias das variáveis entre grupos de empresas agregadas conforme alguma característica em comum. Por exemplo, as empresas foram agrupadas em três categorias conforme o tamanho da frota de operam: "Pequenas", "Médias" e "Grandes" transportadoras. Isso permite a análise da influência do tamanho da empresa nas diferentes variáveis representadas pela sua média nos três grupos.

Esse tipo de procedimento pode deixar a desejar no que se refere à análise da significância dos resultados, o que dificulta as inferências estatísticas. Isso advém do

\footnotetext{
${ }^{25}$ Tal experiência pôde ser comprovada na fase de testes do questionário.
} 
desconhecimento das distribuições de probabilidade das variáveis estudadas, bem como da restrição quanto ao tipo de dado levantado.

Sendo assim, nas situações onde as diferenças foram relativamente pequenas, evitou-se inferir sobre os resultados. Receberam maior atenção aquelas situações nas quais as comparações apresentaram diferenças consideráveis e condizentes com o esperado.

Da mesma forma que a média dos valores de uma variável, o seu desvio padrão também foi utilizado. Esse parâmetro é fundamental para algumas situações nas quais se faz necessária uma indicação da variabilidade existente na amostra.

A utilização de recursos gráficos também colaborou para o entendimento dessas análises.

Em algumas situações procedeu-se com comparações entre valores de duas variáveis de uma mesma empresa. Nesses casos, matrizes algébricas foram construídas, recebendo a denominação de "Matrizes Comparativas", em cujas linhas representou-se uma variável e nas suas colunas, a variável em comparação.

Além disso, para a comparação entre resultados de duas variáveis de uma mesma empresa, utilizou-se um teste não-paramétrico denominado genericamente de "Teste dos Sinais". Segundo Hoffmann (1991), testes não-paramétricos “... podem ser aplicados sem a necessidade de estabelecer uma pressuposição a respeito da distribuição da variável" (pág. 213).

O "Teste dos Sinais" foi utilizado em algumas análises com o objetivo de testar a hipótese de que as variáveis em comparação diferem quanto à sua grandeza (não são estatisticamente iguais).

Considera-se $D_{\mathrm{i}}$, a diferença entre duas variáveis comparativas $A$ e $B$, ou seja, $D_{\mathrm{i}}$ $=A_{\mathrm{i}}-B_{\mathrm{i}}$. O teste, portanto, é utilizado para testar a hipótese de que a mediana de $D$ é igual a zero. O número de observações com $D$ diferente de zero é representado por $n$. Conforme Hoffmann (1991), se $n>25$, utiliza-se uma aproximação normal da binomial, com a seguinte fórmula: 


$$
Z=\frac{Y-0,5-0,5 \cdot n}{0,5 \cdot \sqrt{n}}
$$

Supondo-se que a variável $A$ seja maior que $B$ em $Y$ casos, aplica-se a expressão (1) para obter-se o $Z$ calculado, que deve ser comparado com o $Z$ tabelado, conforme o nível de significância desejado. Caso o $Z_{\text {(calculado) }}$ seja maior que $Z_{\text {(tabelado), rejeita-se a }}$ hipótese de que as variáveis sejam iguais, em detrimento da hipótese de que $A$ seja maior que $B$.

\subsubsection{Modelos de Resposta Qualitativa}

Esses modelos têm em comum o fato de que a variável dependente apresenta-se na forma discreta. Aplicações desses modelos no estudo de funções de utilidade para a compra de seguros foram abordadas por Friedman (1974), Cicchetti \& Dubin (1994) e Marquis \& Holmer (1996).

Segundo McFadden (1974), é possível deduzir de um modelo de escolha individual, propriedades do comportamento de escolha da população. Em seu trabalho, esse autor procura formular modelos econométricos do comportamento da escolha da população, a partir de distribuições de escolhas individuais.

Para aquele autor, o estudo do comportamento da escolha deve ser composto por:

1. objetos de escolhas e o conjunto de alternativas disponíveis aos tomadores de decisão;

2. atributos observáveis dos tomadores de decisão; e

3. modelo de escolha e comportamento individual, e a distribuição das características da escolha na população.

No modelo proposto para a análise do comportamento das empresas de transporte como consumidoras de seguro de transporte, a variável dependente discreta assumirá valores que codificam uma determinada escolha por compra de seguros 
A estrutura geral desses modelos é baseada na análise de probabilidades. Partindo-se de uma representação adotada por Greene (1993), pode-se ilustrar a idéia do modelo que será adotado da seguinte maneira:

$\operatorname{Prob}($ comprar o seguro $j)=\operatorname{Prob}(Y=j)=F$ [efeitos relevantes: parâmetros]

Modelos de demanda agregada geralmente são baseados em observações de grupo de indivíduos, enquanto que modelos de demanda desagregada - que é o caso em questão - são baseados nas observações de escolhas individuais. Dessa maneira, pode-se esperar que modelos deste tipo apresentem uma melhor representação da realidade. Ainda que essas colocações tenham sido feitas por Ortúzar \& Willumsen (1994) para modelos de demanda por transporte, acredita-se na sua validade para a demanda por outros serviços, inclusive serviços de seguros.

Em geral, os modelos de escolha discreta postulam que: "... a probabilidade de indivíduos escolherem uma dada opção é função de suas características sócioeconômicas e da atratividade relativa da opção" (Ortúzar \& Willumsen, 1994, p.208).

A representação da atratividade de uma opção é dada pelo o conceito de Utilidade. De maneira a se prever se uma determinada ação será feita, o valor da sua utilidade deve ser comparado com a utilidade da ação alternativa, e transformada em uma probabilidade, a qual apresenta um valor entre zero e um (Ortúzar \& Willumsen, 1994).

Sendo assım, especifica-se a seguinte Função de Utilidade von NeumannMorgenstern (Função de Utilidade Esperada) para as empresas de transporte no que se refere à demanda por seguros de responsabilidade civil para cargas:

$$
U\left(W ; c, i, \varepsilon_{i}\right)
$$

onde $W$ representa a "riqueza" das empresas (wealth); $c$ é o conjunto de características das empresas tomadoras de decisão; $i$ é o "estado" em que se verifica a utilitade $(i=1$ : com seguro; $i=2$ : sem seguro); e $\varepsilon_{i}$ é o erro aleatório. 
Assumindo-se que os erros aleatórios sejam separáveis, obtém-se a seguinte função:

$$
U\left(W ; c, i, \varepsilon_{i}\right)=\hat{U}(W ; c, i)+\varepsilon_{i}
$$

As empresas maximizam sua utilidade adquirindo o seguro se a utilidade com o seguro for maior que a utilidade sem o seguro, ou seja, se

$$
U\left(W-S ; c, 1, \varepsilon_{1}\right) \geq p \cdot U\left(W-D ; c, 2, \varepsilon_{2}\right)+(1-p) \cdot U\left(W ; c, 2, \varepsilon_{2}\right)
$$

onde $S$ é o custo do seguro; $D$ é a perda incorrida com um sinistro; e $p$ é a probabilidade de ocorrência do sinistro ("risco").

Considerando-se, novamente, os erros separáveis:

$$
\hat{U}(W-S ; c, 1)+\varepsilon_{1} \geq[p \cdot \hat{U}(W-D ; c, 2)+(1-p) \cdot \hat{U}(W ; c, 2)]+\varepsilon_{2}
$$

Portanto, a probabilidade de um seguro ser adquirido é função da diferença de utilidade $(\Delta V)$ nos dois estados: "comprar seguro" e "não comprar seguro", ou seja,

$$
\Delta V=\hat{U}(W-S ; c, 1)-[p \cdot \hat{U}(W-D ; c, 2)+(1-p) \cdot \hat{U}(W ; c, 2)]
$$

Os atributos da Função Utilidade que recebem maior atenção neste trabalho são aqueles relacionados ao parâmetro $c$ (características das empresas tomadoras de decisão). As variáveis $W$ (riqueza), $S$ (custo do seguro), $D$ (valor da perda), e $p$ (probabilidade de ocorrência da perda) são indiretamente consideradas pelas variáveis utilizadas.

A não existência de dados detalhados dificulta a utilização direta das variáveis $W$, $S, D$ e $p$. Espera-se que a influência dessas variáveis seja captada por outras informações. O tamanho da frota da empresa (TFROTA) pode ser uma proxy para a "riqueza" da empresas $(W)$. A localização geográfica $(L O C A L G)$ e o número de roubos 
sofridos pela empresa $(N R O U B O)$ apresentam relação com a probabilidade de ocorrência da perda $(p)$. O tipo de carga $(T C A R G A)$, por sua vez, relaciona-se com o valor da perda $(D)$. O custo do seguro $(S)$ é uma informação um tanto quanto difícil de ser obtida para os seguros de carga pois está relacionado a uma série de fatores (tipo de carga, distância do frete, região de origem e destino, etc.) e só poderia ser identificado com estudos caso a caso.

A diferença de utilidade pode ser representada da seguinte forma:

$$
\Delta V=\beta^{\prime} x
$$

Sendo assim, o estudo da demanda é baseado na probabilidade de um seguro ser adquirido, que por sua vez é função da diferença de utilidade $(\Delta V)$ nos dois estados contigentes. Os modelos de escolha discreta são utilizados para estimar as características dessa demanda pois permitem atribuir valores discretos para a variável dependente, no caso, "0" se o seguro não for utilizado, e "l" se o seguro for utilizado.

Os modelos básicos de variável dependente discreta são o modelo de probabilidade linear, o próbite (probit) e o lógite (logit).

A característica básica dos modelos próbite e lógite é a de que as predições são apresentadas por um valor entre 0 e 1 , o que permite uma melhor indicação da probabilidade de ocorrência de determinado evento. Isso não ocorre para o modelo de probabilidade linear, fazendo com que esse modelo apresente-se menos interessante (Gujarati, 1995).

Já a principal diferença entre os modelos lógite e próbite está na função de probabilidade cumulativa que relaciona as variáveis explicativas com a dependente, sendo que para o primeiro modelo, essa função é do tipo logística, e para o segundo, do tipo normal (Pindyck \& Rubinfeld, 1991).

No presente estudo, duas alternativas são consideradas: i) fazer um seguro; e ii) não fazer o seguro. Na primeira, são incluídas empresas que, com alguma frequência utilizam-se dos seguros em estudo, enquanto que na segunda, são consideradas apenas aquelas que nunca fazem esses seguros. 
Neste trabalho opta-se pelo lógite, cuja função de distribuição é a do tipo "logística".

A distribuição logística é bastante similar à normal, com maior diferença nas suas extremidades. A princípio, a logística pode apresentar uma vantagem em relação à normal, no sentido de ser mais sensível a valores extremos das variáveis independentes (Greene, 1993).

Sendo assim, o modelo assume os seguintes valores:

$$
\begin{aligned}
& P(Y=1)=F\left(\beta^{\prime} x\right) \\
& P(Y=0)=1-F\left(\beta^{\prime} x\right)
\end{aligned}
$$

onde $\beta$ reflete o impacto das variações de $x$ nas probabilidades, representando o conjunto de coeficientes a serem estimados. Por sua vez, $x$ é o conjunto de variáveis independentes, descritas no início deste capítulo.

Com a distribuição logística sendo adotada, a função $F$ apresenta o seguinte formato

$$
P(Y=1)=\frac{e^{\beta^{\prime} x}}{1+e^{\beta^{\prime} x}}
$$

ou apenas,

$$
=\Lambda\left(\beta^{\prime} x\right)
$$

O método mais indicado para a estimação desse tipo de modelo é o de máxima verossimilhança, cuja função conjunta é a seguinte:

$$
L=\prod\left[F\left(\beta^{\prime} x_{i}\right)\right]^{y_{i}}\left[1-F\left(\beta^{\prime} x_{i}\right)\right]^{1-y_{i}}
$$

O software a ser utilizado para estimar o modelo é o Limdep, desenvolvido por Greene (1987). 


\section{RESULTADOS}

\subsection{Características Gerais da Amostra}

Os índices de retorno dos questionários são apresentados à Tabela 30, atestando uma média superior a $25 \%$.

Tabela 30. Tamanho da amostra selecionada, número de questionários respondidos e indice de retorno.

\begin{tabular}{cccccc}
\hline \multirow{2}{*}{ Região } & \multicolumn{2}{c}{ Questionários Enviados } & \multicolumn{2}{c}{ Questionários Recebidos } & Índice de \\
& $\begin{array}{c}\text { Número de } \\
\text { Empresas (A) }\end{array}$ & Participação & $\begin{array}{c}\text { Número de } \\
\text { Empresas (B) }\end{array}$ & & Participação \\
\cline { 2 - 5 } Retorno \\
Norte/Nordeste & 157 & $20,1 \%$ & 26 & $13,0 \%$ & $16,6 \%$ \\
Centro-Oeste & 90 & $11,5 \%$ & 22 & $11,0 \%$ & $24,4 \%$ \\
Sudeste & 231 & $29,5 \%$ & 96 & $48,0 \%$ & $41,6 \%$ \\
Sul & 304 & $38,9 \%$ & 56 & $28,0 \%$ & $18,4 \%$ \\
\hline TOTAL & 782 & $100,0 \%$ & 200 & $100,0 \%$ & $25,6 \%$ \\
\hline
\end{tabular}

Segundo Gil (1987), o índice de retorno de questionários tem se situado na faixa de 10 a 20\%. Para Goode et al. (1968) esse índice deveria variar entre 20 e 70\%. Não há, portanto, um consenso nesse sentido. Para esta pesquisa, o índice médio de retorno foi de 25,6\%, variando entre um máximo de 41,6\% para a Região Sudeste, e um mínimo de $16,6 \%$ para as Regiões Norte/Nordeste. Consequentemente, segundo as referências citadas, esses índices podem ser considerados satisfatórios.

Deve-se ressaltar que nos casos em que se adotou o procedimento de contato telefồnico prévio com as empresas, o índice de retorno passou para $51,27 \%$, o que mostra a importância dessa técnica que foi aplicada a 158 das 782 empresas componentes da amostra.

As características básicas da amostra são ilustradas na Tabela 31 . 
Tabela 31. Características básicas da amostra.

\begin{tabular}{cccc}
\hline Variável & Valor & $\mathrm{N}^{\circ}$ empresas $\left({ }^{*}\right)$ & Participação \\
\hline Tipo de Estabelecimento & Matriz & 182 & $91,5 \%$ \\
(ESTABEL) & Filial & 17 & $8,5 \%$ \\
Classe das Empresas & ETC & 180 & $90,5 \%$ \\
$(C L A S S E)$ & TCP & 18 & $9,0 \%$ \\
& TA & 1 & $0,5 \%$ \\
\hline
\end{tabular}

$\left.{ }^{*}\right) \mathrm{N}^{\circ}$ de empresas que responderam às questões referentes a essas variáveis.

Observa-se uma clara predominância de estabelecimentos matrizes, assim como de empresas que transportam cargas de terceiros (ETC). Isso é algo desejável, como já foi mencionado no capítulo metodológico. Quando for necessário, essas variáveis servirão para separar a amostra.

As informações sobre a localização geográfica das empresas da amostra (LOCALG) são bastante relevantes, uma vez que há a preocupação de que a amostra esteja condizente com a população. A Tabela 32 mostra a comparação entre a distribuição geográfica das empresas segundo o IBGE e a distribuição das empresas amostradas.

Tabela 32. Comparativo da participação das empresas por Unidade da Federação.

\begin{tabular}{ccc}
\hline Estado & $\begin{array}{c}\text { PATR 1990 (IBGE) } \\
(\% \text { das Empresas) }\end{array}$ & $\begin{array}{c}\text { Amostra } \\
(\% \text { das Empresas })\end{array}$ \\
\hline São Paulo & $33,18 \%$ & $30,00 \%$ \\
Rio Grande do Sul & $14,30 \%$ & $10,50 \%$ \\
Minas Gerais & $13,12 \%$ & $12,00 \%$ \\
Santa Catarina & $11,22 \%$ & $6,50 \%$ \\
Paraná & $10,31 \%$ & $11,00 \%$ \\
Rio de Janeiro & $5,35 \%$ & $3,50 \%$ \\
Bahia & $2,05 \%$ & $3,50 \%$ \\
Goiás & $1,61 \%$ & $5,00 \%$ \\
Pernambuco & $1,47 \%$ & $2,00 \%$ \\
\hline
\end{tabular}


Tabela 32. Comparativo da participação das empresas por Unidade da Federação (continuação).

\begin{tabular}{ccc}
\hline Estado & $\begin{array}{c}\text { PATR 1990 (IBGE) } \\
(\% \text { das Empresas })\end{array}$ & $\begin{array}{c}\text { Amostra } \\
(\% \text { das Empresas })\end{array}$ \\
\hline Espírito Santo & $1,43 \%$ & $2,50 \%$ \\
Mato Grosso do Sul & $0,87 \%$ & $1,00 \%$ \\
Ceará & $0,79 \%$ & $2,00 \%$ \\
Pará & $0,67 \%$ & $1,00 \%$ \\
Mato Grosso & $0,64 \%$ & $2,50 \%$ \\
Paraiba & $0,55 \%$ & $0,50 \%$ \\
Rio Grande do Norte & $0,40 \%$ & $2,50 \%$ \\
Sergipe & $0,35 \%$ & $0,00 \%$ \\
Alagoas & $0,32 \%$ & $0,00 \%$ \\
Distrito Federal & $0,30 \%$ & $2,50 \%$ \\
Maranhão & $0,23 \%$ & $0,00 \%$ \\
Piaui & $0,21 \%$ & $0,50 \%$ \\
Amazonas & $0,19 \%$ & $0,50 \%$ \\
Rondônia & $0,17 \%$ & $0,00 \%$ \\
Tocantins & $0,17 \%$ & $0,00 \%$ \\
Acre & $0,05 \%$ & $0,50 \%$ \\
Amapá & $0,05 \%$ & $0,00 \%$ \\
Roraima & $0,01 \%$ & $0,00 \%$ \\
\hline
\end{tabular}

A localização geográfica ( $L O C A L G)$ das empresas pesquisadas, portanto, está em conformidade com os dados do IBGE, como demonstra a Tabela 32. Ocorrem pequenas diferenças em alguns Estados, mas que estão localizadas em regiões menos representativas em relação ao número total de empresas.

Um outro aspecto importante refere-se à participação das empresas conforme o tipo de carga operada (TCARGA). Utilizou-se também, a título de comparação, os dados da PATR do IBGE. As Figuras 8 e 9 mostram essa participação segundo o IBGE e a amostra obtida. respectivamente. 


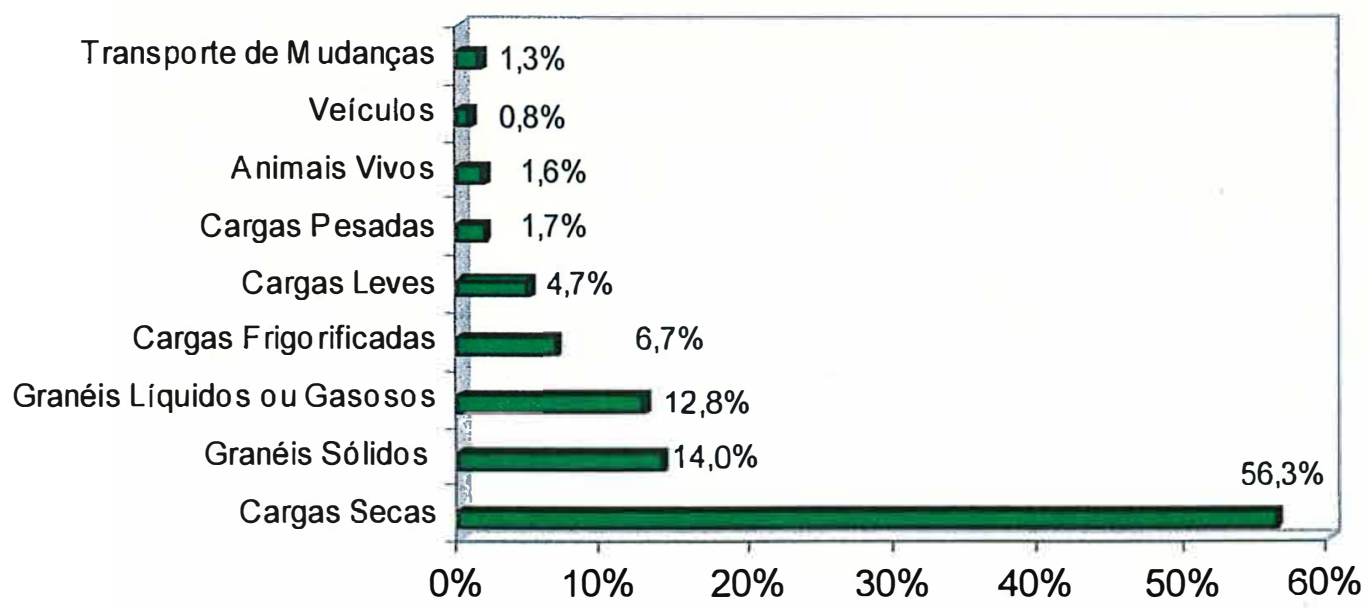

Empresas

Figura 8. Participação das empresas por tipo de carga operada, 1996 (Fonte: PATR/IBGE).

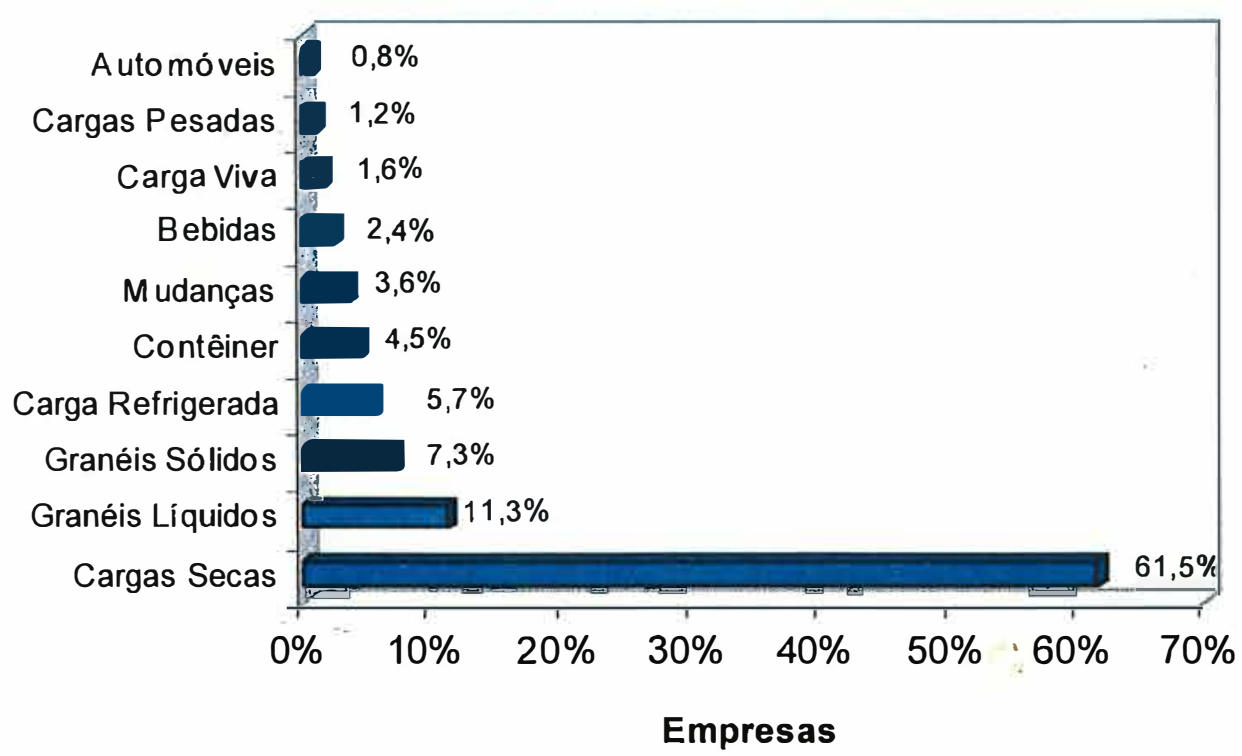

Figura 9. Participação das empresas da amostra conforme tipo de carga operada.

Como pode ser percebido, para este trabalho utilizou-se uma nomenclatura um pouco distinta da utilizada pelo IBGE. Essa adaptação objetivou facilitar o entendimento por parte dos entrevistados, além de estar mais adequada, atualmente, à realidade do 
setor. Mesmo com essas modificações, pode-se dizer que a amostra condiz com a realidade no que se refere ao tipo de carga transportada pelas empresas.

As informações referentes ao tamanho da frota das empresas (TFROTA) podem ser observadas na Figura 10. A PATR não levanta informações sobre o tamanho das empresas, o que impede uma comparação.

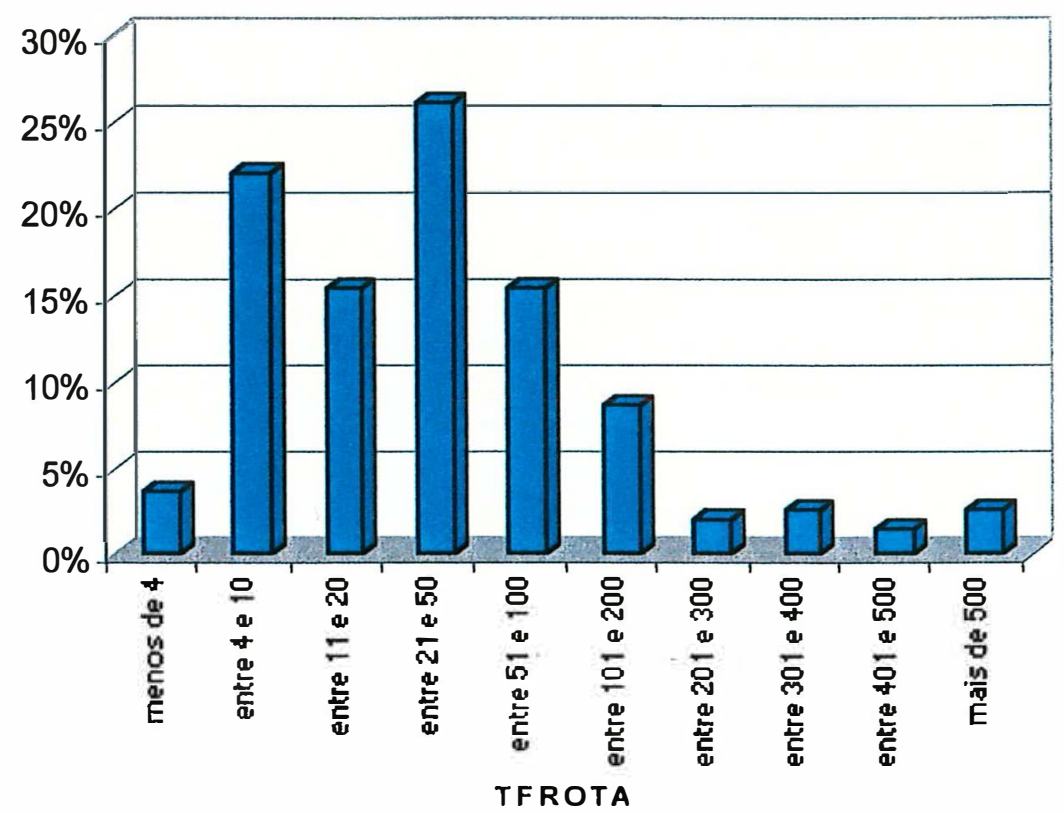

Figura 10. Participação das empresas da amostra conforme o tamanho de sua frota (TFROTA).

Há uma predominância de duas categorias de TFROTA: "entre 4 e 10 veículos", compreendendo $22,1 \%$ das empresas; e "entre 21 e 50 veículos", com 26,2\% das empresas. Em um nível mais agregado observa-se que mais de $67 \%$ das empresas amostradas operam com até 50 veículos.

Outra informação básica relevante está relacionada à idade média da frota das empresas, representada pela variável IFROTA. A Figura 11 permite uma visualização da distribuição dessas idades. 


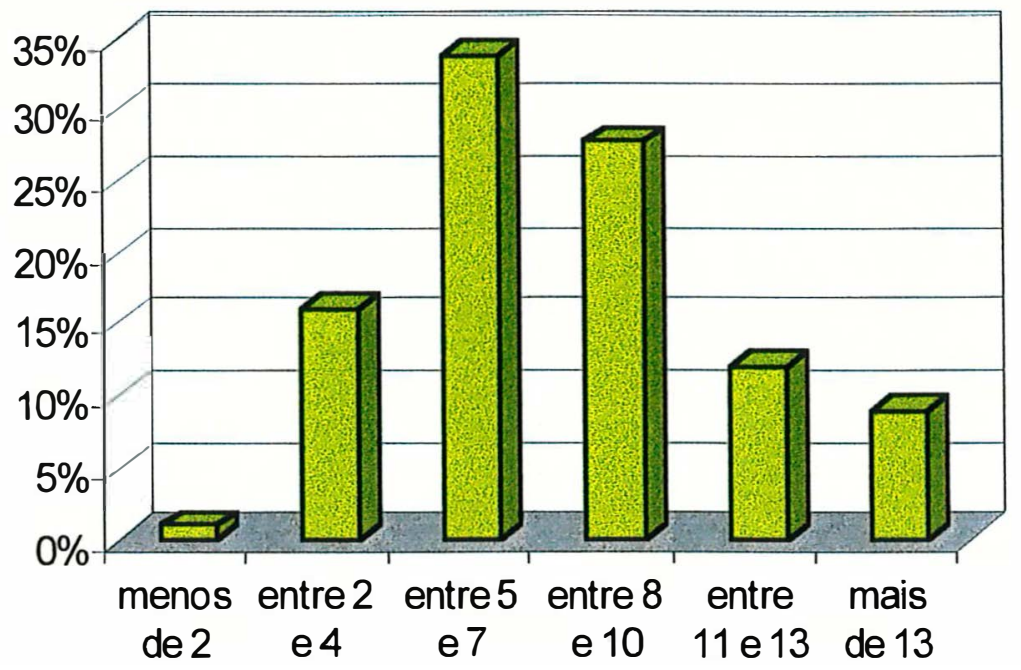

IFROTA

Figura 11. Participação das empresas da amostra conforme a idade média de sua frota (IFROTA)

Segundo os dados obtidos, predominam frotas com idade média entre 5 e 7 anos, sendo que sua distribuição apresenta um formato que lembra uma curva normal ${ }^{26}$.

\subsection{Experiência das empresas com o roubo de cargas}

Antes da verificação das hipóteses propostas, são abordadas as experiências das empresas com o roubo de cargas. Essa informação prévia é fundamental no sentido de conhecimento do comportamento dessas empresas como demandantes de seguro, comportamento esse que sustenta as hipóteses do trabalho.

A variável $N R O U B O$ - representando o número de roubos de cargas sofridos pelas empresas nos últimos 5 anos - é a principal informação para esta análise ${ }^{27}$. Para tanto, são descartadas aquelas empresas que apresentam menos de 5 anos de atividade $(F U N D A C=3)$, o que poderia prejudicar a amostra. Essas empresas descartadas

\footnotetext{
${ }^{26}$ Não faz parte dos objetivos deste trabalho uma análise mais aprofundada da distribuição estatística da variável IFROTA.

${ }^{27}$ Ressalta-se que houve problemas no dimensionamento das alternativas propostas para a variável NROUBO: a alternativa "entre 6 e 10 vezes" sobressaiu-se em relação às demais; a alternativa "mais de 30 vezes", por sua vez, ficou superestimada, não refletindo com a precisão necessária a ocorrência dos eventos. A complexidade do assunto superou o empenho no sentido de evitar problemas dessa natureza quando da aplicação do teste do questionário.
} 
correspondem a $6 \%$ da amostra. A Figura 12 ilustra a participação das empresas da amostra em função da variável $N R O U B O$.

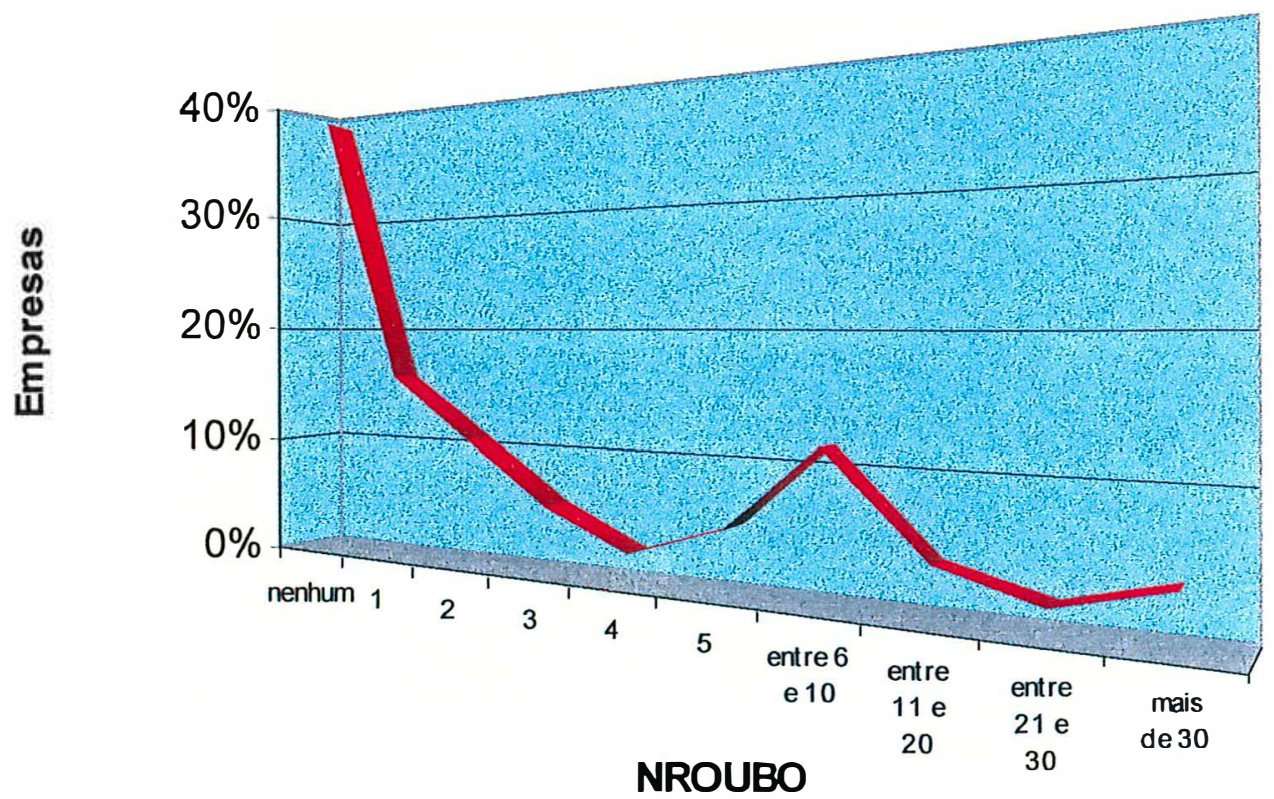

Figura 12. Participação das empresas da amostra em função do número de roubos de cargas sofridos pela empresa nos últimos 5 anos (NROUBO).

A Figura 12, isoladamente, não sugere muita informação, pois não é considerado o tamanho das empresas, que certamente apresenta relação com o número de roubos. Contudo, a importância dessa figura está no fato de mostrar que apenas $38 \%$ das empresas não sofreram algum roubo de carga nos últimos 5 anos, ou seja, $62 \%$ das empresas sofreram pelo menos 1 roubo de cargas no período considerado, o que claramente reflete a importância do problema em questão.

Por sua vez, a consideração do tamanho da empresa (TFROTA) juntamente com o NROUBO, fornece informações mais precisas sobre o assunto. A Tabela 33 apresenta a média do número de roubos sofridos pelas empresas, ordenadas conforme o tamanho da frota que operam (TFROTA). Empresas com até 20 veículos são consideradas "pequenas empresas"; aquelas que operam entre 21 e 100 veículos são denominadas "médias empresas"; e, finalmente aquelas com mais de 100 veículos são consideradas "grandes empresas". 
Tabela 33. Média do número de roubos sofridos pelas empresas nos últimos 5 anos (NROUBO) ordenadas conforme o tamanho da frota que operam (TFROTA).

\begin{tabular}{cccc}
\hline & Empresas & \\
& Pequenas & Médias & Grandes \\
\hline NROUBO & 0,93 & 3,97 & 15,12 \\
(média da variável) & & & \\
\hline
\end{tabular}

Um resultado já esperado refere-se à relação direta existente entre TFROTA e $N R O U B O$, ou seja, à medida que aumenta a exposição das empresas ao risco - devido à existência de um maior número de veículos - tende a aumentar o número de sinistros.

Todavia, mesmo que essa tendência exista, há uma grande variabilidade do número de eventos sofridos pelas empresas dentro de uma mesma categoria de tamanho de frota, como pode ser observado na Figura 13.

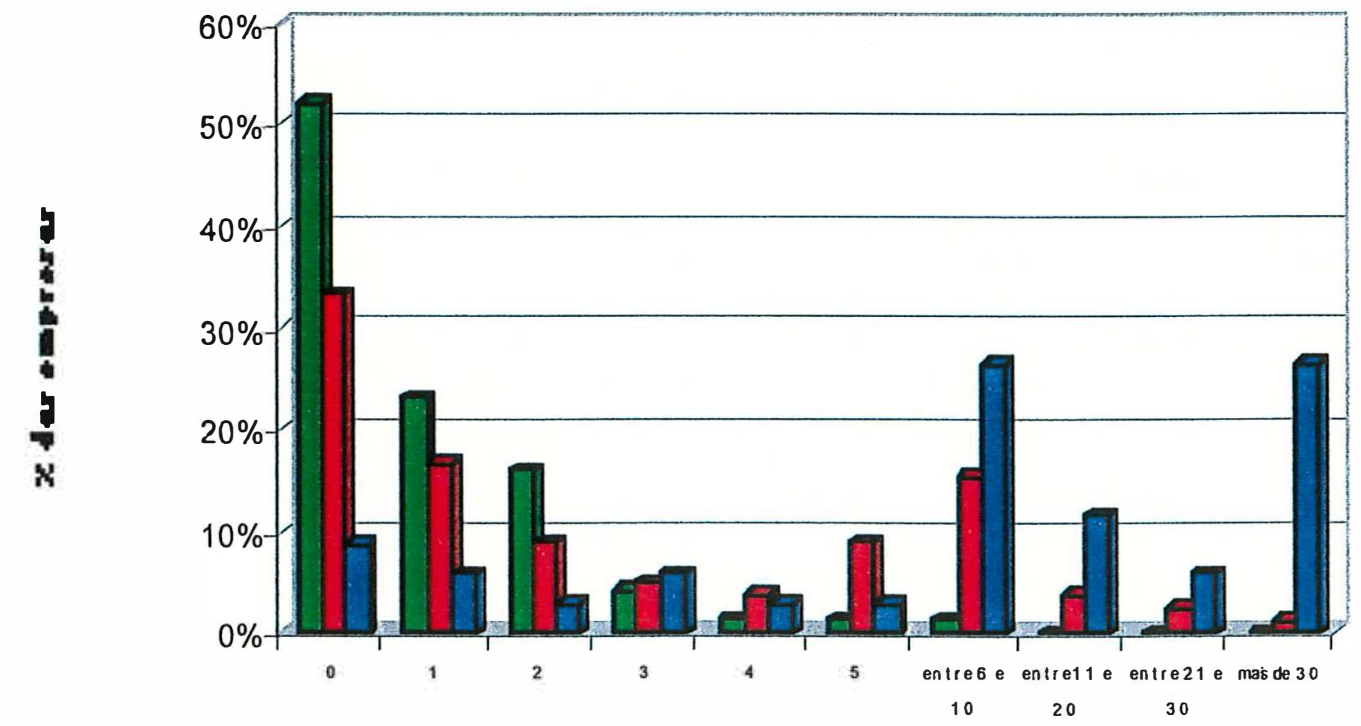

Pequenas Médias Grandes

NROUBO

Figura 13. Frequência das empresas - ordenadas conforme o tamanho de sua frota - em função do número de roubos de cargas sofridos nos últimos 5 anos. 
Primeiramente, deve-se reconhecer que parte dessa variabilidade pode ser oriunda da própria amplitude das categorias de TFROTA propostas. Isso, porém, não pode ser utilizado para explicar as grandes variações do $N R O U B O$ nos diferentes grupos de empresas, como apresentado na Figura 13.

Uma segunda explicação está relacionada às características intrínsecas da atividade de transporte, tais como o tipo de carga e a região de atuação da empresa. Essas duas variáveis devem apresentar alguma relação com a ocorrência de roubos, o que será analisado oportunamente.

A terceira e talvez a mais importante explicação - e também a mais difícil de ser verificada - está relacionada ao fato de que o $N R O U B O$ é consequência dos diferentes procedimentos adotados pelas empresas como forma de tratamento do risco.

Para se verificar essas explicações, é necessário a utilização de uma variável que considere a relação entre o número de roubos e o tamanho da frota das empresas. Essa variável recebe a denominação de $E R 5$ e representa a experiência de cada empresa com seus respectivos tamanhos de frota - em casos de roubos de cargas nos últimos cinco anos, ou seja:

$$
E R 5=\frac{N R O U B O}{T F R O T A}
$$

Portanto, ER5 é uma proxy para medir a intensidade do problema de roubo enfrentado pelas empresas. A Figura 14 traz as distribuições de frequência relativa e acumulada dessa variável. 


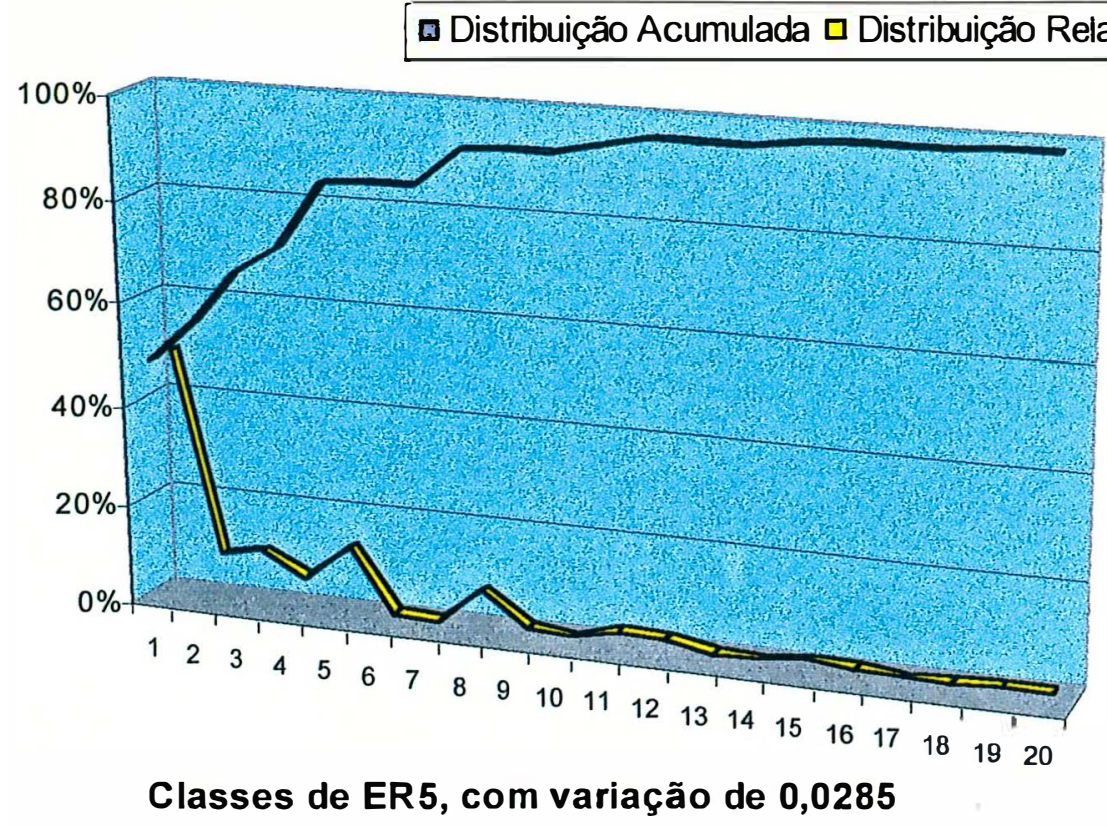

Figura 14. Distribuições de Probabilidade da Variável ER5.

Os valores de ER5 foram agrupados em classes com amplitude de 0,0285 , que compõem o eixo das abcissas. Como é de se esperar, o comportamento dessa variável guarda grande semelhança com o do $N R O U B O$, ratificando mais uma vez a relação direta entre o tamanho da frota de uma empresa e o número de ocorrências de roubos de carga em seus veículos.

De posse da variável $E R 5$, pode-se proceder à análise da relação entre a ocorrência de roubo e as características das empresas.

A primeira característica abordada é o tipo de carga transportada, captado pela variável $T C A R G A$, sugerida como segunda explicação para a variabilidade no número das ocorrências.

Espera-se que cargas denominadas genericamente de "cargas secas" sejam as mais visadas pelos assaltantes. Essas cargas apresentam características que favorecem esse tipo de evento, tais como a facilidade relativa no seu fracionamento e manuseio, facilidade de colocação no mercado informal e certa dificuldade de serem identificadas após sua distribuição. São exemplos os eletrodomésticos, alimentos manufaturados, cigarros, produtos farmacêuticos, vestuário, etc. 
Utilizando-se os dados obtidos na amostra, comparou-se a experiência das empresas com o roubo de cargas (ER5), conforme o tipo de mercadoria operada (Tabela $34)$.

Tabela 34. ER5 das empresas conforme o tipo de carga que operam.

\begin{tabular}{ccccc}
\hline \multirow{2}{*}{ Parâmetros } & \multicolumn{4}{c}{ ER5 das Empresas } \\
\cline { 2 - 5 } & $\begin{array}{c}\text { todas } \\
(\mathrm{A})\end{array}$ & $\begin{array}{c}\text { que transportam } \\
\text { carga seca } \\
(\mathrm{B})\end{array}$ & $\begin{array}{c}\text { que transportam carga } \\
\text { seca apenas } \\
(\mathrm{C})\end{array}$ & $\begin{array}{c}\text { que não transportam } \\
\text { carga seca } \\
(\mathrm{D})\end{array}$ \\
\hline Média & 0,0794 & 0,0948 & 0,1048 & 0,0303 \\
Desvio Padrão & 0,1077 & 0,1139 & 0,1167 & 0,0671 \\
$\mathrm{~N}^{\circ}$ empresas (n) & 180 & 136 & 106 & 44 \\
\hline
\end{tabular}

Observa-se que a média de $E R 5$ para as empresas que operam apenas com cargas secas (coluna $\mathrm{C}$ ) é superior à das empresas que não transportam esse tipo de carga (coluna D). O desvio padrão também é superior no caso das primeiras, confirmando a grande variabilidade de ocorrência do roubo de cargas em empresas com atributos semelhantes.

Os dados da amostra sugerem que a experiência de empresas especializadas no transporte de carga seca é, em média, 3 vezes mais problemática em relação ao roubo de cargas.

Além do tipo de carga, a localização geográfica ( $L O C A L G)$ também deve ser um dos fatores que pode explicar a variabilidade no número de roubos ocorridos.

Tabela 35. ER5 das empresas conforme a sua localização geográfica.

\begin{tabular}{cccc}
\hline \multirow{2}{*}{ Parâmetros } & \multicolumn{3}{c}{ ER5 das Empresas } \\
\cline { 2 - 4 } & todas & com matriz nos Estados de SP e RJ & com matriz nos outros Estados \\
& $(\mathrm{E})$ & 0,1215 & 0,0604 \\
\hline Média & 0,0795 & 0,1329 & 0,0888 \\
Desvio Padrão & 0,1080 & 56 & 123 \\
$\mathrm{~N}^{\circ}$ empresas (n) & 179 & 56 & \\
\hline
\end{tabular}


Observa-se que a média de ER5 das empresas localizadas nos Estados de São Paulo e Rio de Janeiro é superior à das empresas de outras Unidades da Federação, o que corrobora a característica do roubo de cargas no Brasil.

É importante ressalvar que, mesmo comprovando os dados sobre as estatísticas de roubos de cargas, a análise da influência da variável LOCALG na experiência com roubo através dessa metodologia não apresenta precisão apurada. $O$ fato de uma empresa estar localizada em outro Estado não impede que a mesma venha a ter um veículo sinistrado quando em viagem a outra região. Porém, espera-se que as empresas tenham uma maior atuação na região em que estão sediadas.

Após essas considerações sobre a influência do tipo de carga e da localização geográfica das empresas na ocorrência de roubos de cargas, resta a análise da relação entre os procedimentos de gerência de risco adotados pelas empresas e a suas experiências com o roubo.

A investigação a esse respeito é bastante complexa, principalmente no que se refere à sua quantificação. Mesmo que tenham sido levantados os procedimentos utilizados pelas empresas para tratar os riscos de roubo na atividade, apenas um estudo minucioso de todos os eventos ocorridos em cada uma delas poderia apresentar um resultado detalhado a esse respeito.

De qualquer forma, algumas informações obtidas podem fornecer indícios sobre esse assunto, como por exemplo, o fato de que, para algumas empresas, o seguro é o único procedimento adotado para tratar o risco de roubo de cargas. Tais aspectos serão tratados oportunamente no item 4.3.4.

\subsection{Verificação das Hipóteses}

Neste item, são analisadas as hipóteses formuladas no início do trabalho, as quais referem-se às principais características da demanda por seguro de responsabilidade civil de transportadores. 


\subsubsection{Dificuldade de Acesso dos Transportadores ao Serviço de Seguro}

A primeira hipótese a ser explorada refere-se à ocorrência de eventuais impedimentos e dificuldades aos transportadores em relação à obtenção de seguros de responsabilidade civil para cargas.

Essa hipótese surge da constatação de reclamação frequente de transportadores e suas entidades representativas a respeito da existência de empecilhos no que se refere à oferta do seguro RCF-DC por parte das seguradoras.

$\mathrm{Na}$ realidade, o aumento significativo de ocorrências de roubo de cargas nos últimos anos - que teria provocado, consequentemente, um aumento da sinistralidade da carteira do RCF-DC - faz com que a oferta desse seguro passe a ser repensada por parte das seguradoras, ou seja, comę̧am a ser impostas uma série de exigências, condicionando a venda do seguro aos transportadores.

As exigências mencionadas dizem respeito, basicamente, a um maior esforço na gerência do risco por parte dos transportadores. E isso, necessariamente, implica uma revisão dos procedimentos de gerência de risco.

Em relação à sinistralidade do seguro RCF-DC, não se tem disponível uma série longa de dados que permita uma análise criteriosa da sua evolução, e que poderia demonstrar a existência ou não de um comportamento altista ${ }^{28}$. Ainda que essa evolução não seja conhecida, é verdade que esse seguro apresenta uma sinistralidade sensivelmente mais elevada que os outros seguros relacionados à atividade, como já foi abordado no item 2.3 .

Esse comportamento apresenta, ainda, uma relação direta com o fato do RCF-DC ter um mercado mais concentrado, vista a maior especialização que as seguradoras devem ter para trabalhar com o mesmo.

${ }^{28}$ A Fenaseg começou a divulgar as informações de sinistralidade, por tipo de seguro, apenas no ano de 1994. 
É importante salientar que o seguro RCTR-C, por ter sua compra obrigatória aos transportadores, não passa por situação semelhante, mesmo porque não apresenta relação com o roubo de carga - motivo que estaria levando a esse problema de oferta de seguro.

Isso posto, deve-se verificar se realmente ocorre o fato de que algumas empresas transportadoras se deparam com tais dificuldades ao demandarem o RCF-DC.

Inicialmente, ilustra-se na Figura 15 a participação das empresas conforme a frequência com que fazem o seguro RCF-DC (FRERCF).

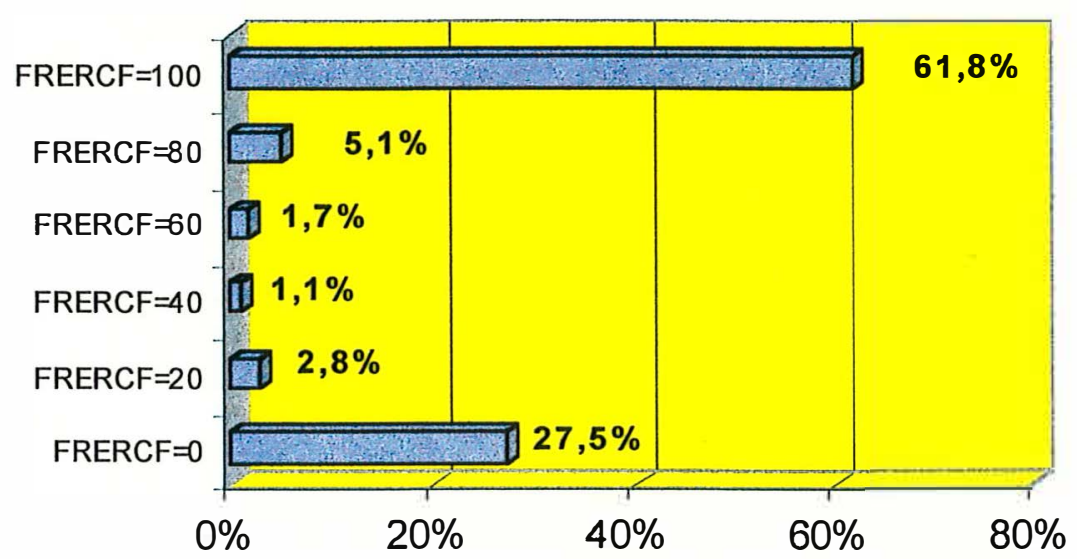

Empresas

Figura 15. Participação das empresas conforme frequência com que utilizam o seguro RCF-DC (FRERCF).

A título de exemplo, 27,5\% das empresas consideradas apresentam um valor de $F R E R C F=0$, ou seja, nunca fazem o seguro RCF-DC.

É importante ressaltar que, para a verificação dessa hipótese, não são consideradas as empresas de transporte de carga própria (CLASSE $=\mathrm{TCP})$, mas apenas aquelas com $C L A S S E=\mathrm{ETC}$ e $C L A S S E=\mathrm{TA}$. Isso porque o seguro RCF-DC, por tratar-se de um seguro de responsabilidade, é um seguro típico de transportadores prestadores de servıços. 
A variável $O F E R C F^{29}$ é a principal informação a ser utilizada para a verificação dos problemas com a oferta do seguro RCF-DC.

Objetivando verificar se as dificuldades de acesso ao RCF-DC (problemas de oferta) estariam se refletindo numa menor frequência de utilização do seguro por parte dos transportadores, deve-se analisar a relação entre as variáveis $O F E R C F$ e $F R E R C F$; apresentada na Tabela 36 .

Tabela 36. Participação das empresas, número de empresas (n) e média da variável OFERCF (problemas de oferta do RCF-DC), conforme as variáveis FRERCF (frequência com que utilizam o seguro RCF-DC) e TFROTA (tamanho da frota)

\begin{tabular}{|c|c|c|c|c|c|c|}
\hline \multirow{2}{*}{ OFERCF $\left({ }^{*}\right)$} & \multirow{2}{*}{$\begin{array}{c}\text { Todas } \\
\text { Empresas }\end{array}$} & \multicolumn{2}{|c|}{$F R E R C F$} & \multicolumn{3}{|c|}{ TFROTA } \\
\hline & & $F R E R C F \neq 0$ & $F R E R C F=0$ & Pequenas & Médias & Grandes \\
\hline 1 & $2,3 \%$ & $0,8 \%$ & $6,8 \%$ & $4,3 \%$ & $0,0 \%$ & $0,0 \%$ \\
\hline 2 & $14,0 \%$ & $14,2 \%$ & $13,6 \%$ & $15,6 \%$ & $13,4 \%$ & $10,0 \%$ \\
\hline 3 & $20,5 \%$ & $18,9 \%$ & $25,0 \%$ & $22,9 \%$ & $19,4 \%$ & $20,0 \%$ \\
\hline 4 & $63,2 \%$ & $66,1 \%$ & $54,5 \%$ & $57,1 \%$ & $67,2 \%$ & $70,0 \%$ \\
\hline (n) & 171 & 127 & 44 & 70 & 67 & 30 \\
\hline Média & 3,77 & 3,50 & 3,27 & 3,33 & 3,54 & 3,60 \\
\hline
\end{tabular}

$\left(^{*}\right) 1$ = sempre encontrou problema de oferta; 2 = encontrou problema várias vezes; 3 = encontrou problema pelo menos uma vez; e 4 = nunca encontrou problemas de oferta.

Quando separadas as empresas nos grupos " $F R E R C F \neq 0$ " (aquelas que utilizam o RCF-DC) e " $F R E R C F=0$ " (aquelas que não o utilizam), observa-se que os problemas de oferta tendem a ser mais evidentes no segundo grupo. Nesse último, $45,4 \%$ (resultado de $6,8 \%+13,6 \%+25,0 \%)$ das empresas já tiveram algum problema $(O F E R C F<4)$, enquanto

\footnotetext{
${ }^{29} \mathrm{Na}$ realidade, a informação contida na variável $O F E R C F$ está baseada na experiência do transportador com problemas na oferta do RCF-DC, e não necessariamente na sua relação atual com esse problema. Essa foi a forma mais indicada para abordar o assunto, pois não faria muito sentido basear-se apenas no que ocorre atualmente com o transportador, pois o mesmo pode estar tendo acesso ao seguro oferecido por determinada seguradora, após ter encontrado muitos problemas com outras seguradoras, ou então, após ter atendido uma série de exigências impostas por essas empresas.
} 
que no grupo das empresas que utilizam o seguro, esse percentual cai para $33,9 \%$ (resultado de $0,8 \%+14,2 \%+18,9 \%$ ).

As médias de OFERCF dos grupos mencionados anteriormente também diferem, valendo 3,27 para "FRERCF=0" e 3,50 para "FRERCF $\neq 0$ ". A significância dessas diferenças pode ser questionável, refletindo porém uma tendência esperada: a de que as dificuldades de acesso ao seguro, resultantes de problemas de oferta, tendem a diminuir a frequência com que as empresas utilizam o RCF-DC.

Ainda que a comparação entre esses dois grupos seja importante, a informação mais relevante está no grupo "FRERCF $\neq 0$ ", no qual observa-se o problema enfrentado por empresas que realmente demandam o seguro. O grupo " $F R E R C F=0$ ", por si só, dificulta a identificação das empresas que não estão utilizando o seguro devido a esse problema, ou simplesmente por falta de interesse.

Quando comparadas as categorias de empresas conforme o seu tamanho, percebe-se que, à medida que esse tamanho diminui, os problemas de oferta tendem a aparecer mais intensamente. Observa-se ainda que as diferenças são mais sensíveis entre pequenas e médias empresas que entre essas últimas e as grandes, à exceção dos casos de $O F E R C F=2$. Portanto, parece razoável afirmar que, de uma maneira geral, as empresas pequenas enfrentam mais problemas de oferta que as médias e grandes.

Os principais motivos que estariam levando a esses problemas podem ser divididos em dois grupos:

i) dificuldade das empresas transportadoras em atender às exigências de seguradoras no que concerne à utilização de procedimentos de gerência de risco.

Em vista da alta probabilidade de ocorrência de roubo de determinadas cargas em certas regiões, a adoção de técnicas e/ou equipamentos objetivando a redução desse risco acaba sendo fundamental para a atividade. Há, contudo, custos envolvidos nesse processo, que muitas vezes não são compensados economicamente, principalmente para empresas de menor porte ou menos estruturadas. Essas, consequentemente, acabam enfrentando problemas quando da demanda do seguro, exatamente por serem consideradas mais susceptíveis ao sinistro. 
Deve ficar claro ainda que há uma seleção natural entre as empresas conforme o tipo (valor) de carga que lhes é entregue para o transporte, ou seja, embarcadores de cargas valiosas certamente procuram entregar suas cargas a transportadores que consideram mais estruturados, e que garantam uma segurança mínima na atividade. Isso, naturalmente, tende a fazer com que transportadoras mais especializadas recebam cargas mais valiosas (mais visadas pelos assaltantes), enquanto aquelas menos especializadas, menos estruturadas, recebem cargas menos valiosas (menos visadas). Existem, obviamente, as devidas exceções. Acredita-se, assim, que a "discriminação" entre transportadoras - em relação à oferta de RCF-DC pelas seguradoras - esteja motivando a seleção natural pelos embarcadores.

ii) reduzido volume de prêmios movimentado.

Durante a pesquisa, várias empresas manifestaram encontrar problemas de oferta do RCF-DC não necessariamente pela falta de segurança que representam à seguradora, mas sim, por movimentarem volumes relativamente pequenos de prêmios do seguro, o que, segundo elas, seria algo indesejável pelas seguradoras e/ou corretoras, frente à possibilidade de ocorrência do sinistro.

Portanto, tudo indica que há, além de problemas em relação ao risco apresentado pelos transportadores, o interesse de que esses últimos movimentem um volume elevado de prêmios, objetivando compensar, de certa forma, o risco envolvido na atividade. A uma seguradora pode ser mais interessante receber, por exemplo, $R \$ 1$ milhão em prêmios anuais de determinada transportadora, mesmo que a sinistralidade dessa empresa seja $80 \%$, que receber $\mathrm{R} \$ 3$ mil de uma pequena transportadora com sinistralidade significativamente mais baixa.

$\mathrm{Na}$ realidade, esses dois grupos de motivos mencionados, que estariam levando a problemas de oferta, são plenamente compreensíveis, ou seja, o comportamento "discriminatório" por parte de seguradoras/corretoras apresenta fundamento diante da situação de alto risco decorrente da falta de segurança na atividade de transporte rodoviário de carga no Brasil. 
As considerações colocadas neste item não permitem refutar a hipótese de que estaria ocorrendo impedimentos e dificuldades aos transportadores em relação à obtenção de seguros de responsabilidade civil para cargas - no caso o RCF-DC (o "seguro de roubo").

$\mathrm{O}$ problema de oferta do RCF-DC existe em consequência do alto risco da atividade, fazendo com que poucas seguradoras atuem nesse mercado, oferecendo cobertura mediante exigências que visam redução do risco por parte das transportadoras, assim como movimentação de volume elevado de prêmios. Muitas são as transportadoras que não apresentam condições para atender a essas exigências.

É verdade também que o problema do roubo de carga no País é relativamente novo, e ao mencionar que algumas transportadoras “...não apresentam condições para atender às exigências das seguradoras..." deve-se considerar que, dentre essas condições, está a própria filosofia de administração das empresas. Essas condições não seriam apenas financeiras, mas também relacionadas à concepção de gerência de risco que, se em outros tempos não era exigida, vem se tornando fundamental para o bom desempenho do negócio de transportes.

\subsubsection{Exigências sobre os Transportadores em relação à Compra de Seguro}

As exigências tratadas nesta segunda hipótese estão relacionadas, primeiramente, àquelas impostas por parte da legislação para a compra de alguns seguros, no caso o RCTR-C, obrigatório aos transportadores. Segundo, às exigências por parte dos próprios embarcadores que - ao entregarem suas mercadorias aos transportadores - estariam exigindo desses últimos uma comprovação de que a sua carga está coberta pelos seguros necessários.

A legislação federal impõe aos transportadores a obrigação de compra do seguro RCTR-C sempre que uma mercadoria lhe seja entregue para o transporte. Da mesma forma, o seguro de transporte de embarcadores, cuja apólice básica é denominada de "Riscos Rodoviários" (RR), também é obrigatório a esses indivíduos. 
Todavia, o órgão que seria responsável pela fiscalização desse mercado - a SUSEP (Superintendência de Seguros Privados) - acaba não desempenhando essa função, por motivos diversos e que fogem ao propósito desta pesquisa. O importante é que a ausência de fiscalização, em muitos casos, acaba por permitir a prática da atividade de transporte sem a contratação dos devidos seguros, seja por parte de transportadores ou de embarcadores.

A verificação da efetividade das exigências legais não é algo trivial. É bastante difícil concluir que determinado seguro está sendo comprado simplesmente por ser imposto pela legislação. De qualquer forma, a variável $F R E R C T$ - frequência com que os transportadores compram o RCTR-C - é uma fonte de informação que permite algumas conclusões.

Caso as empresas seguissem as imposições legais, todas deveriam adquirir o RCTR-C para a totalidade das cargas que transportam, ou seja, esperar-se-1a que a variável FRERCT assumisse uma frequência de 100\% (FRERCT $=100)$, para todas as empresas, o que resultaria em uma média da variável igual a 100 e seu desvio padrão igual a zero. A Figura 16 ilustra a percentagem das empresas ${ }^{30}$ conforme a frequência com que adquirem - ou averbam - o RCTR-C, que é obrigatório por lei. É utilizada uma amostra de 178 empresas.

\footnotetext{
${ }^{30}$ Não considera as empresas de transporte de carga própria (CLASSE=TCP).
} 


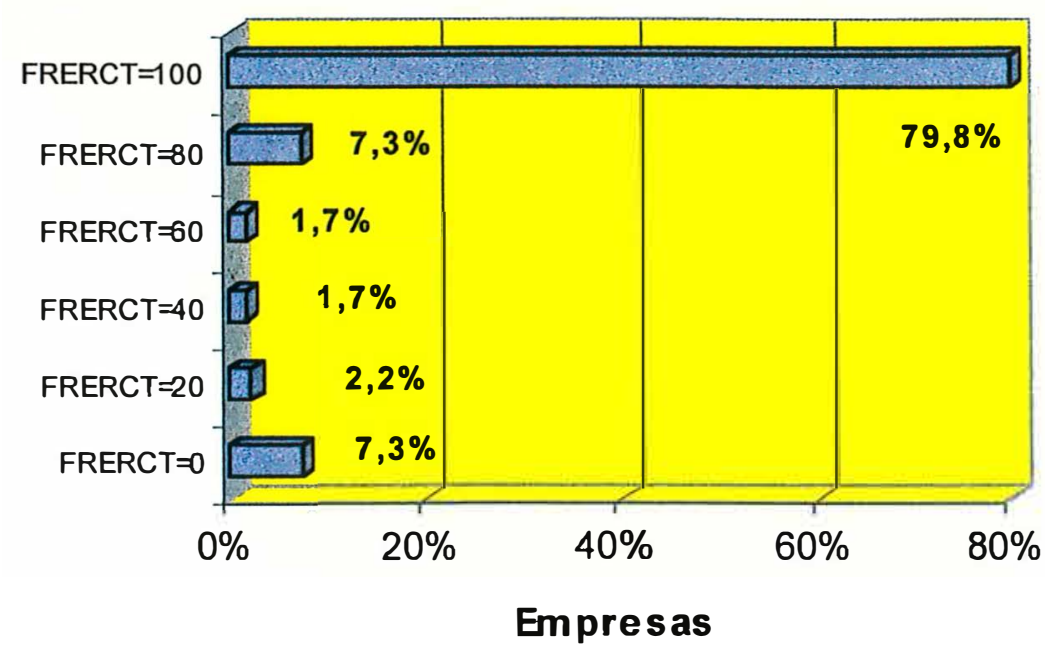

Figura 16. Participação das empresas conforme frequência com que utilizam o seguro RCTR-C (FRERCT).

Os resultados mostram que apenas $80 \%$ das empresas fazem o RCTR-C em todas as cargas que transportam, existindo um percentual de $7 \%$ das empresas que nunca fazem o seguro. A média da variável $F R E R C T$ é igual 87,5 , e seu desvio padrão igual a 29,2 .

Consequentemente, pode-se concluir que o fato do seguro RCTR-C ser obrigatório por lei, não implica que todas as empresas venham a utilizá-lo. Todavia, como já foi comentado, é bastante difícil identificar as empresas que fazem o seguro, pelo simples fato do mesmo ser obrigatório.

Uma ressalva nesse sentido deve ser feita. A experiência junto às empresas - seja pela aplicação das entrevistas, seja pelas manifestações de seus indivíduos em matérias da imprensa pesquisadas - mostra que muitas delas seguidamente lembram o fato da obrigatoriedade do RCTR-C, o que poderia estar influenciando indiretamente na concepção administrativa dessas empresas. Assim, a demanda pelo seguro - nesses casos - teria caráter "automático", sofrendo forte influência dessa imposição legal. Em outras palavras, mesmo que existam empresas que não demandem o RCTR-C, como demonstram os dados, há também aquelas que têm essa demanda implicitamente condicionada pela imposição legal.

Além dessas considerações, uma outra forma que pode servir para avaliar o efeito da imposição legal sobre o RCTR-C, é uma comparação de sua frequência de utilização 
com a frequência do RCF-DC, cuja compra não é obrigatória por lei. Comparando-se as figuras 15 e 16, observa-se uma frequência menor em relação à utilização do RCF-DC. Objetivando uma comparação mais apurada nesse sentido, é criada uma "Matriz Comparativa" utilizando-se as informações de FRERCT e FRERCF. Os dados obtidos da amostra são tabulados nessa matriz, resultando na Figura 17.

A primeira informação em cada célula refere-se à $F R E R C T$, enquanto a segunda refere-se à $F R E R C F$. Portanto, a célula " 0 - 80", por exemplo, compreende as empresas que nunca fazem o seguro RCTR-C e que fazem o seguro RCF-DC em $80 \%$ dos fretes praticados. Observa-se que $1,69 \%$ das empresas estão nessa situação.

\begin{tabular}{|c|c|c|c|c|c|c|c|}
\hline & \multicolumn{6}{|c|}{ FRERCT } \\
\hline & & $0 \%$ & $20 \%$ & $40 \%$ & $60 \%$ & $80 \%$ & $100 \%$ \\
\hline \multirow{6}{*}{ FRERCF } & $0 \%$ & $7,30 \%$ & $0,00 \%$ & $0,00 \%$ & $0,00 \%$ & $0,00 \%$ & $0,00 \%$ \\
\hline & $20 \%$ & $1,12 \%$ & $1,12 \%$ & $0,00 \%$ & $0,00 \%$ & $0,00 \%$ & $0,00 \%$ \\
\hline & $40 \%$ & $1,12 \%$ & $0,56 \%$ & $0,56 \%$ & $0,00 \%$ & $0,00 \%$ & $0,00 \%$ \\
\hline & $60 \%$ & $0,56 \%$ & $0,00 \%$ & $0,00 \%$ & $1,12 \%$ & $0,00 \%$ & $0,00 \%$ \\
\hline & $80 \%$ & $1,69 \%$ & $0,56 \%$ & $0,56 \%$ & $0,56 \%$ & $3,93 \%$ & $0,00 \%$ \\
\hline & $100 \%$ & $15,73 \%$ & $0,56 \%$ & $0,56 \%$ & $0,00 \%$ & $0,56 \%$ & $61,80 \%$ \\
\hline
\end{tabular}

Figura 17: Matriz Comparativa FRERCT x FRERCF: participação das empresas conforme frequência com que utilizam os seguros RCTR-C e RCF-DC, respectivamente.

Verifica-se que o terço superior da matriz apresenta apenas valores nulos. Isso advém da legislação dos seguros de responsabilidade civil de transportadores, que exige que o RCF-DC seja feito apenas em conjunto com o RCTR-C ${ }^{31}$, ou seja, a $F R E R C F$ não poderia ser superior à $F R E R C F$, como confirma a matriz comparativa.

\footnotetext{
31 "O seguro RCF-DC é facultativo e só poderá ser contratado em conjunto com o RCTR-C" (pág. 41) (Funenseg, 1994).
} 
A Matriz Comparativa permite também a análise conjunta das frequências de demanda. Observa-se que $61,8 \%$ das empresas da amostra sempre fazem os dois seguros. Por outro lado, 7,3\% das mesmas nunca utilizam-se desses serviços. Outro dado importante é o de que $15,7 \%$ das empresas, apesar de sempre utilizarem o RCTR-C, não o fazem para o RCF-DC.

Enfim, especificamente nos casos em que $F R E R C T>F R E R C F$, encontram-se 43 das 178 empresas utilizadas para esta análise, o que equivale a $24,2 \%$ dos casos, confirmando, consequentemente, a maior frequência com que é demandado o seguro RCTR-C.

Obviamente que essa diferença não pode ser atribuída exclusivamente ao fato da exigência legal. Porém, é mais uma informação que deve ser levada em consideração.

A segunda forma de imposição, que pode estar ocorrendo sobre a demanda dos transportadores em relação aos seguros de responsabilidade civil, refere-se às exigências por parte dos embarcadores. É importante mencionar também que essas duas formas de exigências - a legal e a dos embarcadores - podem e devem estar correlacionadas, ou seja, o fato do RCTR-C ser obrigatório por lei daria aos embarcadores o "direito" de exigir dos transportadores a sua utilização.

As variáveis utilizadas para captar a exigência dos embarcadores sobre os transportadores em relação à compra dos seguros RCTR-C e RCF-DC, são a EXIRCT e EXIRCF, respectivamente. Essas assumem os valores 1, 2 e 3 , conforme os transportadores respondem que os embarcadores - para os quais operam - sempre exigem, exigem algumas vezes, ou nunca exigem os respectivos seguros. A Figura 18 mostra a participação das empresas conforme os valores assumidos por essas variáveis. 


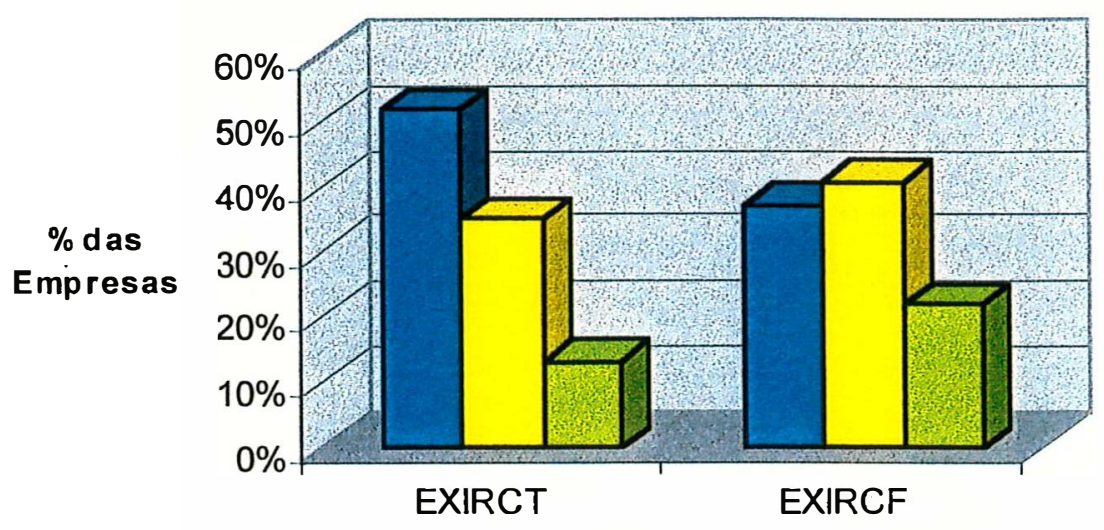

sempre exige $\square$ exige algumas vezes $\square$ nunca exige

Figura 18. Participação das empresas conforme as variáveis EXIRCT e EXIRCF (exigência dos embarcadores para o RCTR-C e o RCF-DC, respectivamente).

O resultado dessas variáveis mostra que o seguro RCTR-C parece ser mass exigido que o RCF-DC, pois $52 \%$ das empresas responderam que seus embarcadores sempre exigem o primeiro seguro, enquanto que apenas $37 \%$ das empresas responderam que isso também ocorre para o segundo. Por outro lado, $13 \%$ das empresas responderam que os embarcadores nunca exigem o RCTR-C, enquanto que, no caso do RCF-DC, esse percentual é de $22 \%$.

Para melhor abordar essa questão, utiliza-se uma matriz comparativa, nos mesmos moldes utilizados para comparar as variáveis FRERCT e FRERCF. Essa matriz consta na Figura 19. 


\section{EXIRCT}

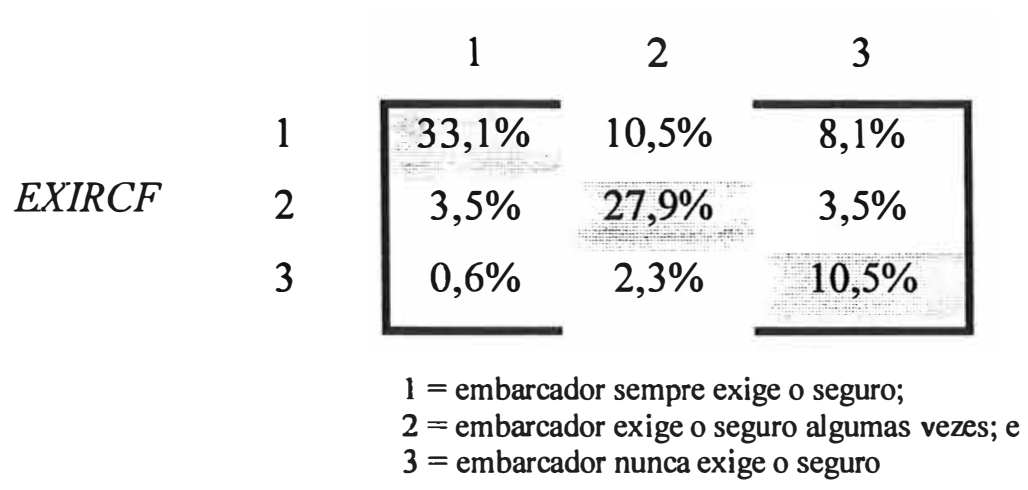

Figura 19: Matriz Comparativa EXIRCT x EXIRCF: participação das empresas segundo exigências que sofrem dos embarcadores para a utilização dos seguros RCTR-C e RCF-DC, respectivamente.

Como já foi mencionado, tudo indica que o RCTR-C é mais exigido pelos embarcadores que o RCF-DC. O somatório das células do terço superior da matriz comparativa mostra que para $22,1 \%$ das empresas, essa afirmação é verdadeira. Contrariamente, em apenas $6,4 \%$ das empresas da amostra ocorre o contrário, ou seja, o RCF-DC é mais exigido que o RCTR-C.

Para concluir essa discussão, procede-se com um teste não-paramétrico, denominado genericamente de "Teste dos Sinais" (Hoffmann, 1991), para se verificar a hipótese de que o seguro RCTR-C é mais exigido que o RCF-DC. Esse teste é indicado para situações em que as variáveis assumem apenas valores ordinais, como é o caso.

Considera-se $D_{\mathrm{i}}$, a diferença entre as exigências em relação ao RCTR-C e ao RCF-DC, ou seja, $D_{\mathrm{i}}=E X I R C T_{\mathrm{i}}-E X I R C F_{\mathrm{i}}$. O teste, portanto, é utilizado para se testar a hipótese de que a mediana de $D$ é igual a zero. O número de observações (diferente de zero) é 49 , portanto $n=49$. Conforme Hoffmann (1991), se $n>25$, utiliza-se uma aproximação normal da binomial, com a seguinte fórmula:

$$
Z=\frac{Y-0,5-0,5 \cdot n}{0,5 \cdot \sqrt{n}}
$$


O seguro RCTR-C é mais exigido que o RCF-DC em 38 casos, portanto, $Y=38$. Aplicando-se na expressão acima, obtém-se um $Z$ calculado igual a 3,71. Como $Z_{(1 \%)}=2,33$ e, consequentemente $Z>Z_{(1 \%)}$, rejeitamos a hipótese de que as exigências são iguais, em detrimento da hipótese de que o RCTR-C é mais exigido pelos embarcadores, em comparação ao RCF-DC.

É importante ainda procurar analisar a que tipo de empresas essas exigências são mais acentuadas. Para tanto, são considerados dois atributos: o tamanho da empresa (TFROTA) e o tipo de carga (TCARGA).

A Tabela 37 ilustra a participação das empresas - divididas em pequenas, médias e grandes - conforme as exigências ${ }^{32}$ que sofrem dos embarcadores.

Tabela 37. Participação das empresas - divididas em pequenas, médias e grandes conforme as exigências que sofrem dos embarcadores para a compra dos seguros RCTR-C e RCF-DC.

\begin{tabular}{ccccc}
\hline Variável & & \multicolumn{3}{c}{ Empresas } \\
& Pequenas & Médias & Grandes \\
\hline $\begin{array}{c}\text { EXIRCT } \\
\text { (exigência para o } \\
\text { RCTR-C) }\end{array}$ & Exige algumas vezes & $40,0 \%$ & $31,8 \%$ & $30,3 \%$ \\
& Nunca exige & $11,4 \%$ & $18,2 \%$ & $9,1 \%$ \\
\cline { 2 - 5 } EXIRCF & Sempre exige & $32,9 \%$ & $37,9 \%$ & $48,5 \%$ \\
$($ exigência para o & Exige algumas vezes & $44,2 \%$ & $36,3 \%$ & $36,3 \%$ \\
RCF-DC) & Nunca exige & $22,9 \%$ & $25,8 \%$ & $15,2 \%$ \\
\hline
\end{tabular}

\footnotetext{
${ }^{32}$ Neste caso, são consideradas apenas as situações em que os seguros sempre são exigidos (EXIRCT ou EXIRCF iguais a 1) e as situações em que nunca são exigidos (EXIRCT ou EXIRCF iguais a 3), deixandose de lado, consequentemente, os casos de EXIRCT ou EXIRCF iguais a 2.
} 
Observa-se, através da Tabela 37, o que foi verificado anteriormente: o RCTR-C é mais exigido que o RCF-DC. Além disso, a tabela sugere que as grandes empresas são as que mais se deparam com as exigências.

$\mathrm{O}$ fato de que as empresas grandes são as mais exigidas no que tange à utilização dos seguros apresenta relação direta com o que foi comentado sobre o critério dos embarcadores para escolha dos transportadores. Como as cargas de maior valor tendem a ser transportadas por empresas maiores (e/ou mais estruturadas), é natural que a essas empresas seja exigido um maior gerenciamento do risco.

O outro atributo considerado é o tipo de carga transportada pelas empresas. Espera-se que transportadoras que operam com cargas visadas sejam mais exigidas em relação à utilização dos seguros, principalmente o RCF-DC.

À semelhança da Tabela 37, foi construída a Tabela 38 com o objetivo de verificar essas exigências conforme o tipo de carga, representado pela variável TCARGA (tipo de carga).

Tabela 38. Participação das empresas - divididas segundo o tipo de carga que operam conforme as exigências que sofrem dos embarcadores para a compra dos seguros RCTR-C e RCF-DC.

\begin{tabular}{|c|c|c|c|}
\hline \multirow[t]{2}{*}{ Variável } & & \multicolumn{2}{|c|}{ Empresas que operam } \\
\hline & & cargas visadas & cargas pouco visadas \\
\hline \multirow{3}{*}{$\begin{array}{c}\text { EXIRCT (exigência } \\
\text { para o RCTR-C) }\end{array}$} & Sempre exige & $50,7 \%$ & $56,7 \%$ \\
\hline & Exige algumas vezes & $37,3 \%$ & $23,3 \%$ \\
\hline & Nunca exige & $12,0 \%$ & $20,0 \%$ \\
\hline \multirow{3}{*}{$\begin{array}{c}E X I R C F \text { (exigência } \\
\text { para o RCF-DC) }\end{array}$} & Sempre exige & $41,5 \%$ & $16,7 \%$ \\
\hline & Exige algumas vezes & $41,6 \%$ & $36,6 \%$ \\
\hline & Nunca exige & $16,9 \%$ & $46,7 \%$ \\
\hline
\end{tabular}


Fazem parte do agrupamento "cargas visadas" as empresas que transportam cargas denominadas "secas" (TCARGA=CS) e/ou aquelas que operam com cargas refrigeradas $(T C A R G A=\mathrm{CR})$. As cargas "pouco visadas" são todas as outras não mencionadas ${ }^{33}$.

A Tabela 38 mostra que há uma maior exigência para a utilização do RCF-DC para o transporte de mercadorias visadas para o roubo. Apenas $16,7 \%$ das empresas que operam com cargas consideradas "pouco visadas" são exigidas a utilizar o seguro, enquanto $41,5 \%$ das empresas que transportam "cargas visadas" deparam-se com exigências dessa natureza.

Assim sendo, constata-se que, de uma maneira geral, há uma relação entre as duas formas de exigências tratadas neste item: a legal e aquela por parte dos embarcadores. É provável que a primeira seja uma abertura para a existência da segunda no caso do RCTR-C, e que isso estaria fazendo com que esse seguro fosse o mais utilizado.

Além disso, sempre houve uma tradição de utilização do seguro RCTR-C por parte dos transportadores, o que não se constata para o RCF-DC, mesmo porque há muitos problemas na oferta deste último.

O costume no uso do RCTR-C ainda resultou de outro comportamento na atividade: muitos transportadores "garantiam" aos embarcadores a indenização nos casos de tombamento da carga, pois dispunham do RCTR-C que, inclusive, ainda hoje é genericamente denominado por muitos de "seguro de tombamento". Esse comportamento dos transportadores era explicado pelo interesse que tinham pela cobrança de um adicional ao valor do frete, denominado de ad valorem. Trata-se de um percentual utilizado para despesas com gerência de risco, entre elas, o pagamento dos prêmios do seguro.

Como a instabilidade econômica dificultava a definição de um valor real para o frete, o ad valorem era utilizado como uma forma de obtenção de um ganho extra pelos

\footnotetext{
${ }^{33}$ Essa separação foi adotada simplesmente para viabilizar a análise. Outros tipos de carga, além das "secas" e "refrigeradas", também são procuradas pelos assaltantes, como por exemplo, automóveis e conteiners, porém, em menor escala.
} 
transportadores, mesmo porque muitas vezes era um valor significativamente superior àquele necessário para despesas com o gerenciamento do risco.

Aquela "garantia" fornecida pelos transportadores influenciou sensivelmente na formação de um costume dos embarcadores em não utilizar o seguro que lhes dizia respeito, o seguro de transporte denominado de "RR". Isso porque, quando da ocorrência de um sinistro, o transportador assumia sua negligência e era indenizado pelo RCTR-C, indenização essa repassada aos embarcadores.

Portanto, um sinistro originado de "tombamento" acabava automaticamente sendo considerado fruto de uma negligência do condutor do veículo, mesmo que isso não fosse exatamente a realidade. Um tombamento não necessariamente advém de uma negligência, caso em que o transportador não deveria ser responsabilizado pelo ocorrido.

Com o início do agravamento do risco do roubo de cargas em meados dos anos 80 , bem como com a estabilização da economia - que dificulta a manutenção de um ad valorem elevado - os transportadores passaram a repensar sua responsabilidade sobre a carga. Trata-se de um processo ainda em desenvolvimento, e que tem gerado conflitos no que concerne à limitação da responsabilidade das partes envolvidas.

De qualquer forma, a hipótese de que há exigências condicionando a demanda por seguros de responsabilidade civil de transportadores não pode ser descartada, sejam elas legais, ou por parte de embarcadores.

\subsubsection{Conhecimento dos transportadores em relação ao Seguro}

A hipótese de que estaria havendo uma falta de conhecimento dos transportadores em relação ao serviço de seguro de carga é a mais difícil de ser verificada pela sua natureza subjetiva.

Entende-se por "conhecimento do serviço de seguro" não apenas o conhecimento da sua operacionalização, cláusulas contratuais e coberturas, mas também a concepção de sua importância para a atividade de transporte, principalmente no relacionamento entre transportadores e embarcadores. 
Como foi abordado no item 2.2, o contrato de seguro de carga geralmente não é um contrato trivial, ou seja, a própria natureza da atividade de transporte exige a manutenção de um contrato aberto, em que os fretes são averbados a cada viagem. Além disso, os prêmios cobrados variam significativamente conforme algumas variáveis, tais como o tipo de carga e as regiões de origem e destino do frete. Sendo assim, podem existir contratos complexos, que acabam por exigir uma atenção constante e minuciosa por parte das empresas, situação essa em que deveria haver um indivíduo, ou um setor, exclusivamente alocado para a execução dessa tarefa.

Todavia, a especialização na administração de uma carteira de seguro de carga pode não ser viável em determinados casos, como por exemplo, nas empresas de pequeno porte. Nesses casos, a tarefa pode ser executada por funcionários que também desempenham outras funções dentro da empresa, como por exemplo, os contadores. $\mathrm{Ou}$ então - e isso é bastante comum - os próprios proprietários assumem essa função.

Vistas as características intrínsecas de uma apólice de seguro de carga, a forma empírica com que muitas empresas são gerenciadas, e sabendo-se que uma apólice de seguro, de maneira geral, é composta por uma série de cláusulas e detalhes, é bastante provável que alguns indivíduos encontrem dificuldade na sua administração.

Para efeito da análise desses fatos no âmbito desta pesquisa, uma das formas encontradas foi o questionamento sobre a "dificuldade" encontrada pelos indivíduos em relação à administração da carteira de seguro de carga nas empresas. Essa informação é tomada como uma indicação do "conhecimento" desses indivíduos em relação ao assunto.

Obviamente que a relação entre esses dois atributos - "desconhecimento" e "dificuldade" - não é assim tão direta, pois um indivíduo pode não ter dificuldade com determinada tarefa, mas ao mesmo tempo, executá-la de uma forma completamente equivocada. De qualquer maneira, foi a alternativa encontrada para o propósito.

Isso posto, passa-se a ilustrar algumas informações obtidas junto às empresas, relacionadas aos aspectos administrativos da carteira de seguros de carga das mesmas ${ }^{34}$.

34 Para essas análises, as empresas de transporte de carga própria (CLASSE=TCP) também são consideradas. 
A variável ESPSEG identifica as empresas que apresentam um indivíduo ou um departamento específico que seja responsável pela administração dos seguros, ou seja, identifica aquelas empresas onde espera-se existir uma certa especialização na condução dessa tarefa. De uma maneira geral, $70 \%$ das empresas não dispõem desse serviço especializado.

É importante, porém, que essa informação seja analisada considerando-se o porte das empresas. Para isso, utiliza-se de maneira conjunta as informações da variável TFROTA, agregada conforme o tamanho das empresas. A Figura 20 mostra essas informações.

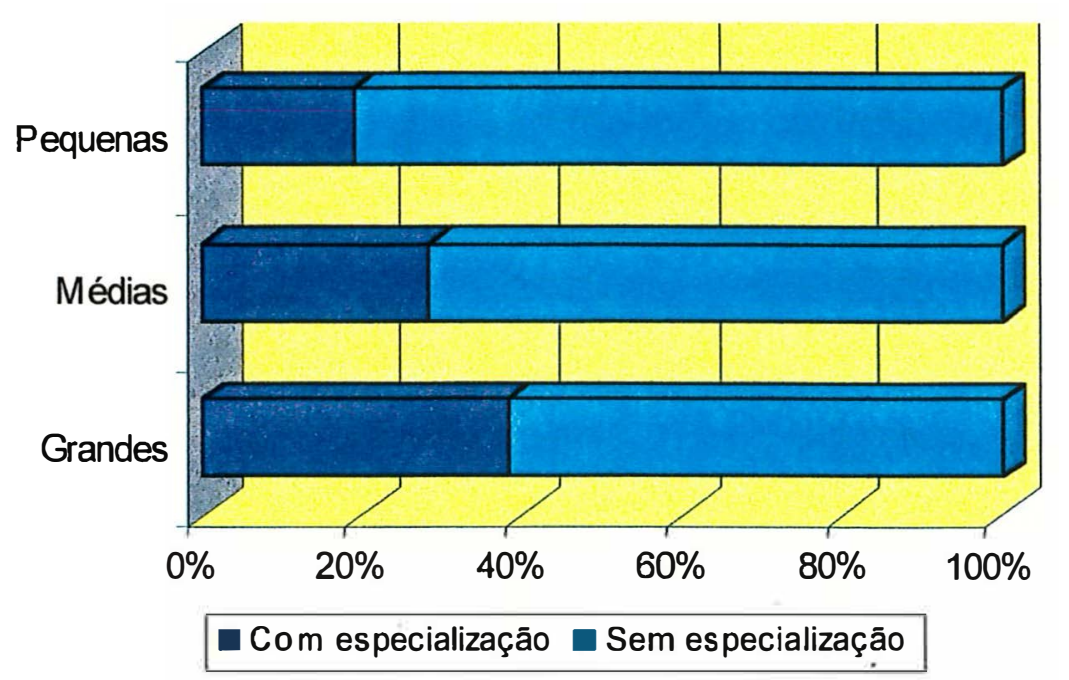

Figura 20. Participação das empresas - separadas conforme o seu tamanho - em termos de especialização na administração dos seguros.

Os dados agregados por tamanho de frota mostram que há uma relação direta entre a especialização na administração dos seguros de transporte e o tamanho das empresas.

Embora seja um comportamento a princípio esperado, percebe-se que essa especialização existe - de uma maneira geral - em um número relativamente reduzido de empresas. No caso das pequenas, apenas $19 \%$ possuem essa característica. No grupo das empresas de grande porte, esse percentual é de $38,2 \%$, o que também não é algo 
muito relevante. É importante mencionar, contudo, que dentre as grandes empresas da amostra, praticamente todas aquelas que operam com mais de 500 veículos dispõem desse serviço especializado.

Ajustando-se um modelo econométrico através de uma regressão, tendo como variável dependente a porcentagem das empresas que apresentam especialização na administração dos seguros (ESPSEG=S) dentro de uma categoria de TFROTA, e como variável independente, o tamanho central da categoria (valores assumidos por TFROTA), obtém-se um resultado bastante satisfatório. A equação ajustada é apresentada a seguir:

$$
\% \text { ESPESG }=(0,195+0,0015 . T F R O T A), 100
$$

O coeficiente de ajuste $\mathrm{R}^{2}$ apresentou um valor de $97 \%$, indicando um resultado satisfatório da regressão. A estatística "t" de Student do coeficiente de TFROTA foi igual a 13,97 , significativo ao nível de $1 \%$.

Na Figura 21, são plotados os valores da porcentagem de ESPSEG em função do TFROTA, para os dados obtidos e para uma previsão a partir da equação estimada ${ }^{35}$.

\footnotetext{
${ }^{35}$ Obviamente que a curva originada de uma regressão linear apresenta-se em forma de reta. Devido à escala utilizada, o gráfico apresentou um aspecto curvilíneo.
} 


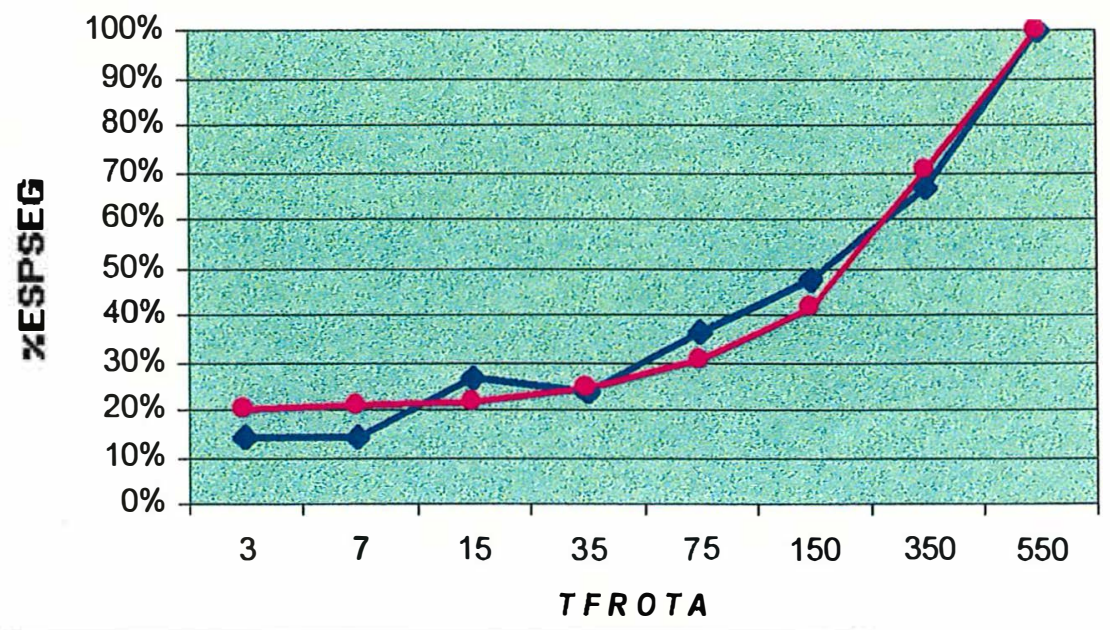

Amostra

Previsão com equação estimada

Figura 21. Porcentagem de empresas com especialização de seguros - em função do tamanho de sua frota - segundo dados da amostra e segundo previsão com equação estimada com esses dados.

A equação estimada pode ser usada para a obtenção da probabilidade aproximada de determinada empresa dispor de um serviço de administração de seguros especializado, conforme o tamanho da frota que opera. Por exemplo, há uma probabilidade de $34,5 \%$ que uma empresa trabalhando com 100 veículos apresente essa especialização.

Procedendo-se de forma análoga, segundo o modelo, empresas com mais de 537 veículos sempre disporiam dessa especialização.

Conclui-se assım, que a especialização das tarefas relacionadas à operacionalização dos contratos de seguro de carga pode ser considerada característica de um grupo relativamente pequeno de empresas, principalmente quando levado em consideração que a maioria dessas empresas operam com menos de 50 veículos, como já foi mencionado.

Uma outra variável relacionada aos aspectos administrativos é a $A D M S E G$, que contém informações sobre a impressão dos indivíduos em relação à operacionalização dos seguros de carga. Tal variável é composta por dois atributos: "dificuldade" e "burocracia". A Tabela 39 ilustra a participação das empresas conforme esses atributos. 
Tabela 39. Participação das empresas segundo a variável $A D M S E G$ (impressão sobre a administração dos seguros).

\begin{tabular}{ccc}
\hline \multirow{2}{*}{ Burocracia } & \multicolumn{2}{c}{ Dificuldade } \\
& $\begin{array}{c}\text { Pequena } \\
(A D M S E G=\text { fácil })\end{array}$ & $\begin{array}{c}\text { Grande } \\
(A D M S E G=\text { difícil })\end{array}$ \\
\cline { 2 - 3 } Não Burocrática & $34,0 \%$ & $8,5 \%$ \\
Burocrática & $41,0 \%$ & $16,5 \%$ \\
\hline
\end{tabular}

A alternativa mas apontada pelas empresas foi aquela que diz que a administração dos seguros de transporte é "fácil, porém burocrática". Segundo os dados obtidos, $41 \%$ das empresas se enquadram nessa categoria. Em seguida aparece a alternativa "fácil e não burocrática", com $34 \%$ das empresas.

Considerando-se os atributos separadamente, obtém-se os valores expostos na Figura 22.

\section{Burocracia}

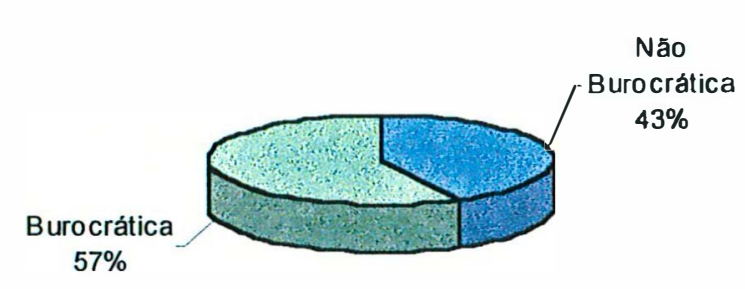

Dificuldade

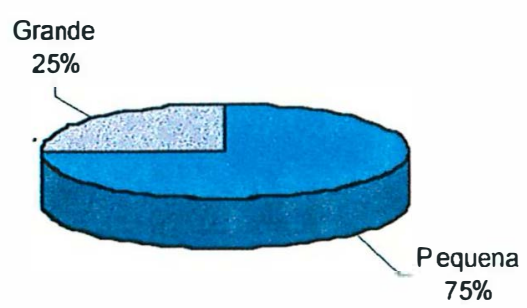

Figura 22. Participação das empresas da amostra segundo os atributos "Burocracia" e "Dificuldade", obtidos da variável $A D M S E G$ (impressão sobre a administração dos seguros).

Percebe-se que, mesmo sendo considerada "fácil" - em $75 \%$ dos casos - a administração dos seguros é tida como "burocrática" para 57\% das empresas entrevistadas. 
É importante ainda verificar a relação entre a $A D M S E G$ e mais outras três variáveis: o tamanho das empresas (TFROTA), a especialização na administração (ESPSEG), e o serviço dos corretores de seguros (SERVCO).

Em relação ao tamanho das empresas, agregando-as conforme vem sendo feito, obtém-se as informações de participação das mesmas em relação à $A D M S E G$. Essas participações estão contidas na Tabela 40.

Tabela 40. Participação das empresas, separadas pelo tamanho de sua frota, segundo a variável $A D M S E G$ (impressão sobre a administração dos seguros).

\begin{tabular}{cccc}
\hline$A D M S E G$ & Pequenas & Médias & Grandes \\
\hline Difícil & $26,67 \%$ & $24,68 \%$ & $18,75 \%$ \\
Burocrática & $61,33 \%$ & $58,44 \%$ & $46,88 \%$ \\
$\mathrm{~N}^{\circ}$ empresas (n) & 75 & 77 & 32 \\
\hline
\end{tabular}

Assim, as empresas de menor porte tendem a avaliar como "mais dificill" e "mais burocrática" a administração dos seguros, em comparação às empresas maiores. Por outro lado, essa diferença não parece ser muito significativa entre as pequenas e médias empresas.

Quando comparadas as variações em um mesmo atributo, entre categorias de empresas de mesmo porte, percebe-se que a diferença de impressão em relação à "burocracia" é maior que a de "dificuldade". Em síntese, isso significaria que as empresas menores "sofrem" relativamente mais com os aspectos burocráticos, que com a dificuldade que têm na execução da tarefa.

Procedendo-se de forma análoga à anterior para as médias e grandes empresas, as diferenças também são consideráveis. O mesmo não ocorre, porém, se comparadas as pequenas com as médias empresas, quando as diferenças tendem a ser irrisórias.

Uma segunda variável a ser considerada juntamente com a $A D M S E G$ é a ESPSEG (especialização na administração de seguros). Ambas estão intimamente ligadas e devem apresentar alguma relação entre si. A Tabela 41 mostra a participação das empresas conforme os valores assumidos por essas variáveis. 
Tabela 41. Participação das empresas segundo as variáveis $A D M S E G$ (impréssão sobre a administração dos seguros) e ESPSEG (especialização na administração dos seguros), analisadas de forma conjunta.

\begin{tabular}{ccc}
\hline ADMSEG & $\begin{array}{c}\text { ESPSEG }=\mathrm{S} \\
\text { (com especialização) }\end{array}$ & $\begin{array}{c}\text { ESPSEG=N } \\
\text { (sem especialização) }\end{array}$ \\
\hline Difícil & $16,7 \%$ & $28,9 \%$ \\
Burocrática & $58,3 \%$ & $57,0 \%$ \\
$\mathrm{~N}^{\circ}$ empresas (n) & 60 & 128 \\
\hline
\end{tabular}

A relação que existe entre as variáveis $A D M S E G$ e ESPSEG refere-se ao atributo "dificuldade", onde espera-se que a não-especialização na administração de seguros seja responsável pela existência de um número maior de empresas que enfrentam dificuldade na execução dessa tarefa.

De acordo com a Tabela 41, apenas $16,7 \%$ das empresas que possuem uma certa especialização com os seguros manifestaram alguma dificuldade em relação a administração desses serviços, enquanto que, quando essa especialização não existe, esse percentual passa para $28,9 \%$.

Esse resultado - da relação $A D M S E G$ vs. ESPSEG - ao que tudo indica, ainda confirma o fato que a manutenção e operacionalização de uma apólice de seguro de carga (principalmente averbações) é naturalmente, ou melhor, intrinsecamente minuciosa, exigente de atenção especial e, consequentemente, reconhecida como "burocrática", independentemente da existência ou não de um serviço especializado para o seu tratamento.

Além desse aspecto da manutenção das apólices, deve-se considerar os trâmites necessários quando da ocorrência de algum sinistro com determinada carga. Seguidamente - por ocasião das entrevistas - os indivíduos lembravam os procedimentos burocráticos necessários para a obtenção da indenização securitária. 
O que chama a atenção, contudo, é o fato de que a diferença em relação à "burocracia", mesmo que não tenha sido verificada quando da consideração da existência ou não de especialização, foi encontrada entre empresas de portes diferentes.

Uma última variável que dever ser considerada na análise da impressão dos transportadores em relação à administração dos seguros é o serviço prestado pelos seus respectivos corretores de seguros.

O corretor de seguros, no caso do transporte rodoviário de carga, apresenta uma função ainda mais evidente que em outros ramos, seja pelas características naturais desse seguro, seja pelo fato de que esse indivíduo também acaba desenvolvendo um papel de orientação às formas de gerência de risco adotada pelos transportadores. Certamente essas duas funções estão intimamente relacionadas, mesmo porque a oferta dos seguros pode estar condicionada à adoção de alguns desses procedimentos. No momento, contudo, o que deve ficar claro é que a existência de um serviço - de qualidade - na corretagem, é fundamental para o desenvolvimento da atividade de transporte de carga.

O contato com algumas empresas estudadas mostrou, também, que são comuns os casos em que os transportadores delegam aos seus corretores toda a responsabilidade pela operacionalização da sua carteira de seguros de carga $^{36}$, ou seja, tais situações demonstram a confiança - e consequentemente, a importância - do serviço de corretagem de seguros.

Mesmo nos casos em que essa relação não é assim tão estreita, espera-se que uma adequada prestação do serviço de corretagem deva facilitar sensivelmente a administração dos seguros por parte dos transportadores. Em outras palavras - e voltando ao propósito inicial - deve-se verificar o grau de relação entre a "satisfação" dos transportadores em relação aos seus corretores - captada pela variável SERVCO - e a avaliação desses transportadores em relação à administração dos seguros (ADMSEG).

Primeiramente, a Figura 23 ilustra a participação das empresas conforme a variável SERVCO.

\footnotetext{
${ }^{36}$ Durante a pesquisa, alguns transportadores insistiam para que a entrevista fosse feita diretamente com o seu corretor, que era quem estava mais ligado ao assunto. Nesses casos, era esclarecida a importância de o transportador responder aos questionamentos e não o corretor de seguros, uma vez que era preciso obter a avaliação que o primeiro fazia do segundo.
} 


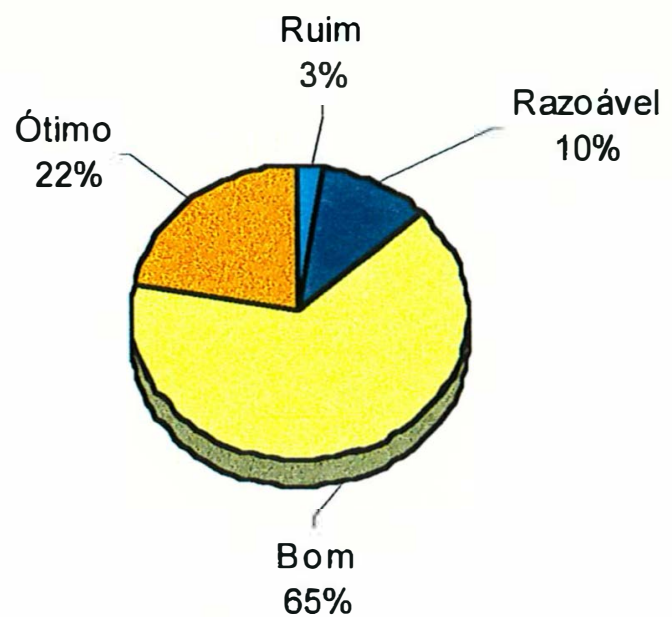

Figura 23. Participação das empresas da amostra segundo a impressão que têm sobre o serviço prestado por seu corretor de seguros (SERVCO).

As informações obtidas mostram que, de uma maneıra geral, as empresas transportadoras parecem estar satisfeitas com o serviço prestado por seus respectivos corretores de seguros de carga. A explicação mais provável para esse fato deve ser a importância que esses corretores representam para a atividade, o que estaria se refletindo em um reconhecimento por parte dos transportadores.

Portanto, mesmo com a existência de problemas de oferta de RCF-DC e com a imposição de uma série de exigências por parte das corretoras/seguradoras para a oferta desse seguro - o que estaria criando um sentimento de conflito, ou até mesmo "antipatia" - os transportadores apresentam uma impressão positiva do serviço prestado por essas empresas.

Ao se considerar a relação entre as variáveis $S E R V C O$ e $A D M S E G$, obtém-se o resultado exposto na Tabela 42. 
Tabela 42. Participação das empresas da amostra conforme as variáveis $A D M S E G$ (impressão sobre a administração dos seguros) e $S E R V C O^{37}$ (avaliação do serviço prestado pelo corretor), analisadas de forma conjunta.

\begin{tabular}{cccc}
\hline \multirow{2}{*}{ SERVCO } & \multicolumn{3}{c}{$A D M S E G$} \\
Ruim/Razoável & Difícil & Burocrática & $\mathrm{N}^{\circ}$ empresas (n) \\
\cline { 2 - 4 } Bom & $37,5 \%$ & $83,3 \%$ & 24 \\
Ótimo & $25,0 \%$ & $58,6 \%$ & 116 \\
\hline
\end{tabular}

Os transportadores que consideram que o serviço de seus corretores seja de melhor qualidade apresentam uma impressão de que a administração dos seguros é "mais fácil" e "menos burocrática", de acordo com as informações contidas na Tabela 42 , sendo que o efeito dessa especialização é maior sobre o atributo "burocracia" que sobre o atributo "dificuldade".

Essas comparações entre variáveis permitem a indicação de que tanto a especialização "dentro" da empresa de transporte (ESPSEG), como a especialização do serviço dos corretores de seguros (SERVCO), tendem a apresentar um efeito positivo no desempenho das mesmas no que se refere ao gerenciamento dos assuntos ligados aos seguros de carga, como era de se esperar.

Mais especificamente, segundo os dados apresentados nas tabelas anteriores, a especialização na administração (ESPSEG) tende a apresentar um efeito significativo sobre o atributo "dificuldade", ou seja, as empresas com ESPSEG=S tendem a não ter dificuldades na administração da carteira de seguros de carga. Ao contrário, aquelas que não dispõem desse serviço manifestaram se deparar mais com esse problema, indicando realmente haver alguma dificuldade (Tabela 41). Através da pressuposição de que

\footnotetext{
37 As empresas que responderam "Ruim" e "Razoável" para a variável SERVCO foram agregadas devido ao baixo percentual de empresas na primeira situação, o que dificultaria a formação de um grupo com um número razoável de observações.
} 
"dificuldade" esteja relacionada com "desconhecimento", pode-se dizer que a hipótese de que estaria havendo um certo desconhecimento por parte das empresas não pode ser descartada.

Já em relação ao atributo "burocracia", a variável que apresentou uma forte relação com o mesmo foi a $S E R V C O$, que capta a avaliação dos transportadores em relação ao serviço (qualidade) prestado por seus corretores que - pressupõe-se também deve apresentar uma relação direta com a especialização desse serviço. Portanto, aqueles transportadores que recebem um serviço de melhor qualidade (especializado) por parte de seus corretores consideram a administração de seguros menos burocrática que os demais (ver Tabela 42). É importante ainda ressaltar que a variável SERVCO também apresentou relação direta com o atributo "dificuldade".

$\mathrm{Na}$ realidade - e isso deve ficar claro - esses dois atributos podem acabar se confundindo um com o outro, pois sua avaliação por parte dos entrevistados é bastante subjetiva, dependendo muito do que os mesmos consideram como algo difícil e burocrático. Entretanto, visto que os dados espelharam um resultado bastante condizente com o esperado, essa distinção parece ter sido assimilada pelos respondentes.

Uma outra análise relevante, relacionada ao conhecimento dos transportadores, é aquela referente ao comportamento dos embarcadores em relação ao seguro $R^{38}$ (o "seguro do embarcador").

O seguro RR sempre deveria ser utilizado pelos embarcadores no transporte de suas mercadorias, independentemente de serem transportados pelos próprios embarcadores ou por transportadores terceiros (ETC ou TA). Todavia, já se observou que tal não ocorre na maioria das situações. Quando questionados os transportadores a respeito desse fato, suas respostas retificaram tal idéia. A Figura 24 ilustra a participação das transportadoras da amostra conforme a variável COMPRR, de onde se verifica que apenas $10 \%$ dos transportadores ${ }^{39}$ afirmaram que os embarcadores utilizam o seguro RR ao entregarem suas mercadorias para o transporte.

\footnotetext{
${ }^{38}$ Ressalta-se, mais uma vez, que "RR" é apenas a cobertura básica do Seguro de Transporte Nacional Terrestre para o setor rodoviário. Utiliza-se a expressão simplificada "Seguro RR" no sentido de facilitar a comunicação.

${ }^{39}$ Não são consideradas as empresas de transporte de carga própria (CLASSE=TCP).
} 


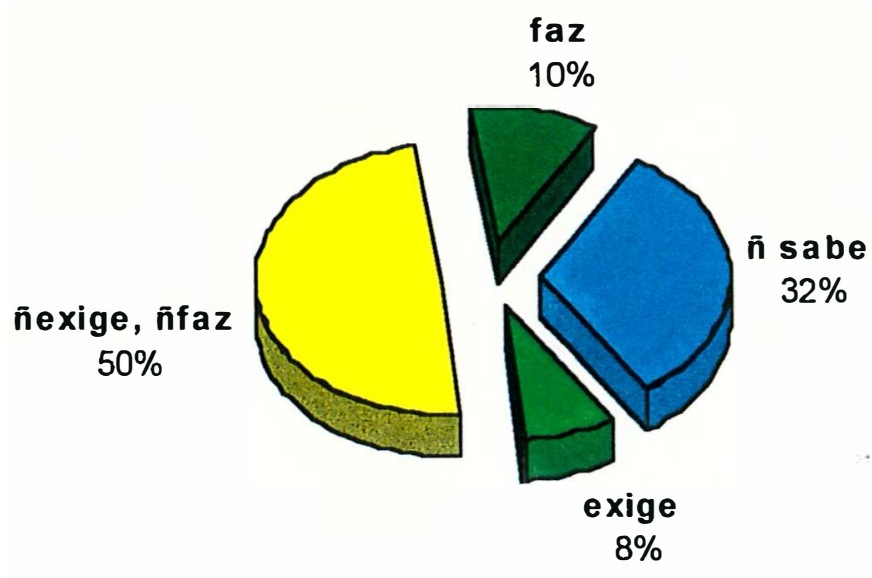

Figura 24. Participação das transportadoras da amostra conforme a variável COMPRR. (comportamento do embarcador em relação ao seguro RR).

Neste momento, é necessário um comentário fundamental. Como foi dito no item 2.2.1, o seguro RR não é exclusivo dos embarcadores, podendo ser utilizado por transportadores. Além disso, é um seguro que apresenta maior número de coberturas que os seguros de responsabilidade civil sendo, portanto, um seguro all risks.

Consequentemente, os embarcadores podem exigi-lo dos transportadores e, em alguns desses casos, em nome dos próprios embarcadores. Isso ocorre, segundo a amostra, com $8 \%$ das transportadoras.

As situações mais comuns, todavia, são aquelas em que os embarcadores não exigem e nem fazem o RR: $50 \%$ das transportadoras responderam nesse sentido.

Finalmente, $32 \%$ dos entrevistados simplesmente não souberam responder à questão, mostrando, por consequência, um grande desconhecimento em relação ao comportamento do embarcador no que concerne à utilização do seguro RR. Esse fato fortalece a idéia de que a hipótese aqui analisada não pode ser refutada.

\subsubsection{Interesse dos transportadores pelo Seguro}

A última hipótese de que trata esta pesquisa é a de que existe um desinteresse natural por parte de alguns transportadores em relação à utilização de seguros para cargas, ou seja, além dos problemas citados até o momento - que podem impedir e/ou dificultar o acesso das empresas transportadoras ao seguro - devem existir também casos 
em que tais servıços não são demandados simplesmente por não interessarem aos potenciais demandantes.

$\mathrm{Na}$ realidade, a própria concepção de gerência de rısco prevê a opção pela retenção do risco através do "não seguro".

Sendo assim, essa "liberdade de escolha" pela não utilização de seguro deveria ser vista como algo óbvio. Contudo, características como a existência de exigências legais podem usurpar dos tomadores de decisão essa opção.

De qualquer forma, procurar-se-á a identificação de casos onde o motivo pela "não demanda" por seguros de transporte seja simplesmente explicado pela "não escolha" dos transportadores.

Espera-se - com a análise desta última hipótese - ter-se tratado os principais motivos que levam ou não os transportadores a utilizarem seguros de carga, enfatizando os seguros de responsabilidade civil: RCTR-C e RCF-DC.

Inicialmente, reporta-se aos comentários a respeito da Figura 16 do item 4.3.2 onde foi abordada a frequência com que as empresas utilizavam o seguro RCTR-C. Os dados obtidos mostram que 7,3\% das empresas amostradas jamais utilizam esse seguro (13 empresas, dentre um total de 179). Considerando-se que não há problemas de oferta desse seguro - por ser compulsório - a primeira explicação que surge é a de que nesses casos há uma simples opção por parte das empresas em não utilizá-lo.

Das 13 empresas que nunca utilizam o RCTR-C, 9 delas afirmaram "não ter" um corretor de seguros, indicando que esse comportamento deve ser algo "estrutural" e não "conjuntural", ou seja, a opção pelo "não seguro" deve fazer parte da concepção administrativa intrínseca dessas empresas, e não ser fruto de ocasiões circunstanciais, como por exemplo, a ocorrência de algum problema financeiro, mesmo porque 5 das 9 empresas afirmaram não terem tido problemas financeiros no último exercício $(F I N A N C=\mathrm{E}$ ou $F I N A N C=\mathrm{L})$.

Além dessas empresas com $F R E R C T=0$, há também aquelas que afirmaram não necessariamente utilizar o RCTR-C em todos os fretes que praticam. Portanto, são 36 empresas $(20,2 \%$ da amostra) que apresentam FRERCT<100. A Tabela 43 apresenta uma comparação entre algumas variáveis nos grupos FRERCT>100 e FRERCT=100. 
Tabela 43. Participação das empresas - agrupadas pela variável FRERCT (frequência com que utilizam o RCTR-C) - conforme algumas variáveis comparativas.

\begin{tabular}{|c|c|c|c|}
\hline \multirow{2}{*}{$\begin{array}{c}\text { Variável } \\
\text { comparativa }\end{array}$} & \multirow{2}{*}{$\begin{array}{c}\text { Atributos } \\
\text { /Parâmetros }\end{array}$} & \multicolumn{2}{|c|}{ Agrupamento conforme a variável $F R E R C T$} \\
\hline & & FRERCT $<100$ & $F R E R C T=100$ \\
\hline \multirow[t]{2}{*}{$\mathrm{N}^{0}$ empresas } & (n) & 36 & 141 \\
\hline & Pequenas & $75,0 \%$ & $32,6 \%$ \\
\hline TFROTA & Médias & $25,0 \%$ & $44,0 \%$ \\
\hline (tamanho da frota) & Grandes & $0,0 \%$ & $56,0 \%$ \\
\hline$\$ R C T R C^{1}$ & "Alto" & $64,7 \%$ & $58,9 \%$ \\
\hline $\begin{array}{l}\text { (impressão sobre o } \\
\text { preço do RCTR-C) }\end{array}$ & $\begin{array}{l}\text { Média da } \\
\text { variável }\end{array}$ & 1,38 & 1,45 \\
\hline $\begin{array}{c}E S P S E G \\
\text { (especialização na } \\
\text { administração dos } \\
\text { seguros) }\end{array}$ & "Sim" & $19,4 \%$ & $30,1 \%$ \\
\hline \multirow{2}{*}{$\begin{array}{c}A D M S E G \\
\text { (impressão sobre a } \\
\text { administração dos } \\
\text { seguros) }\end{array}$} & "Difícil" & $34,4 \%$ & $22,0 \%$ \\
\hline & "Burocrática" & $37,5 \%$ & $58,9 \%$ \\
\hline \multirow{2}{*}{$\begin{array}{c}\text { NOTRCT } \\
\text { (nota para o } R C T R-C)\end{array}$} & $\begin{array}{l}\text { Média da } \\
\text { variável }\end{array}$ & 6,3 & 7,4 \\
\hline & Desvio Padrão & 1,7 & 1,8 \\
\hline
\end{tabular}

Apenas as pequenas e médias empresas da amostra não utilizam RCTR-C em todos os fretes que praticam, com predomínio das primeiras em $75 \%$ dos casos. No agrupamento das empresas que sempre utilizam o seguro $(F R E R C T=100)$, predominam as de grande porte, com $56 \%$ do total. Essa informação sugere que a tamanho da frota pode apresentar certa influência na frequência com que as empresas utilizam o RCTR-C.

$\mathrm{Na}$ realidade, não se pode dizer que "empresas de pequeno porte geralmente não utilizam o RCTR-C em todos os casos", mas sim que "as empresas que não utilizam o RCTR-C em todos os casos, geralmente são de pequeno porte". Mesmo porque, se 
consideradas todas as pequenas empresas da amostra utilizadas nesta análise - em um total de 73 - predominam empresas que sempre utilizam o seguro: 63\% sempre utilizam o seguro, ou seja, a relação TFROTA vs. FRERCT não pode ser considerada unívoca.

Uma importante variável a ser considerada é a impressão que os transportadores têm sobre o preço dos seguros, no caso, o RCTR-C. Essa informação é obtida através da variável $\$ R C T R C$, que pode variar de 1 a 3 , diminuindo à medida que os entrevistados avaliam o preço do seguro mais elevado. Como pode ser observado, as empresas do primeiro agrupamento parecem julgar o preço do seguro mais elevado que as empresas do segundo grupo. Todavia, a diferença é bastante pequena para ser - a princípio considerada significativa.

Sendo assim, a impressão em relação ao preço do RCTR-C não deve apresentar muita influência na decisão de utilizá-lo ou não, mesmo porque os prêmios de seguro geralmente são repassados aos embarcadores através de um valor adicional denominado de ad valorem, como mencionado no item 4.3.2.

Em relação à variável ESPSEG já era de se esperar - em vista do tamanho das empresas, como já comentado - que aquelas que sempre fazem o RCTR-C tendem a apresentar uma maior especialização na administração dos seguros. Isso pode ser percebido na Tabela 43. É bastante difícil, porém, identificar o que seja causa ou consequência, ou seja, se as empresas não têm uma especialização exatamente por não fazer o seguro e, consequentemente não exigir tal especialização; ou se elas não fazem o seguro pelo fato de não haver um indivíduo com conhecimento para tal.

Tal como a variável ESPSEG, a variável ADMSEG apresentou um comportamento condizente com o que já foi exposto no item anterior, ou seja, empresas com menos especialização tendem a achar a administração mais difícil. É o que ocorre com o agrupamento FRERCT<100.

Para o atributo "burocracia" há uma participação menor no agrupamento $F R E R C T<100$, em função do fato de que muitas empresas simplesmente não têm corretor de seguros, ou o utilizam pouco, e consequentemente, acabam não tendo a impressão de burocracia simplesmente por não serem muito expostas à mesma. 
Finalmente, a variável comparativa NOTRCT, que capta a nota fornecida pelos transportadores para a eficiência do seguro RCTR-C, apresentou uma média superior para as empresas que sempre utilizam o seguro, como também pode ser visto na Tabela 43. A variabilidade foi praticamente a mesma, reforçando, de certa forma, a significância das diferença apresentada.

Esse resultado de NOTRCT permite a afirmação de que um dos motivos que deve estar levando algumas empresas a não utilizarem o RCTR-C é a impressão mais negativa que têm sobre a eficiência do mesmo. Inclusive, a média de NOTRCT das 13 empresas que nunca utilizam o seguro - igual a 5,6 - é ainda menor que a média do agrupamento FRERCT<100, de 6,3.

Mesmo com essas diferenças de avaliação, percebe-se que de uma maneira geral as médias das notas atribuídas pelos entrevistados podem ser consideradas satisfatórias. Informações adicionais sobre a variável NOTRCT serão apresentadas oportunamente, juntamente com a variável NOTRCF, referente ao seguro RCF-DC.

O próximo seguro a ser analisado é o RCF-DC. Assim como o RCTR-C, a frequência com que esse seguro é utilizado também já foi apresentada na Figura 15. Como foi demonstrado, a frequência com que as empresas utilizam esse seguro é menor que a frequência do RCTR-C. Das empresas amostradas, 38,2\% delas não fazem o RCFDC em todos os fretes que praticam $(F R E R C F<100)$ e, mais especificamente, $27,5 \%$ jamais utilizam o seguro $(F R E R C F=0)$.

Analogamente à comparação procedida com o RCTR-C, é construída a Tabela 44 para o RCF-DC. 
Tabela 44. Participação das empresas - agrupadas pela variável $F R E R C F$ (frequência com que utilizam o seguro RCF-DC) - conforme algumas variáveis comparativas.

\begin{tabular}{|c|c|c|c|}
\hline \multirow[t]{2}{*}{$\begin{array}{c}\text { Variável } \\
\text { comparativa }\end{array}$} & \multirow[t]{2}{*}{$\begin{array}{l}\text { Atributos } \\
\text { /Parâmetros }\end{array}$} & \multicolumn{2}{|c|}{$\begin{array}{l}\text { Agrupamento conforme a variável } \\
\qquad F R E R C F\end{array}$} \\
\hline & & $F R E R C F<100$ & $F R E R C F=100$ \\
\hline \multirow[t]{2}{*}{$\mathrm{N}^{\circ}$ empresas } & (n) & 66 & 109 \\
\hline & Pequenas & $60,6 \%$ & $30,3 \%$ \\
\hline TFROTA & Médias & $27,3 \%$ & $46,8 \%$ \\
\hline (tamanho da frota) & Grandes & $12,1 \%$ & $22,9 \%$ \\
\hline$\$ R C F D C$ & "Alto" & $76,7 \%$ & $80,9 \%$ \\
\hline $\begin{array}{l}\text { (impressão sobre o } \\
\text { preço do } R C F-D C \text { ) }\end{array}$ & Média da variável & 1,27 & 1,20 \\
\hline $\begin{array}{c}\text { ESPSEG } \\
\text { (especialização na } \\
\text { administração dos } \\
\text { seguros) }\end{array}$ & "Sim" & $22,4 \%$ & $33,9 \%$ \\
\hline \multirow{2}{*}{$\begin{array}{c}A D M S E G \\
\text { (impressão sobre a } \\
\text { administração dos } \\
\text { seguros) }\end{array}$} & "Difícil" & $26,7 \%$ & $23,4 \%$ \\
\hline & "Burocrática" & $53,3 \%$ & $61,3 \%$ \\
\hline \multirow[t]{2}{*}{$\begin{array}{c}\text { NOTRCF } \\
\text { (nota para o RCF-DC) }\end{array}$} & Média da variável & 5,6 & 6,3 \\
\hline & Desvio Padrão & 2,1 & 2,5 \\
\hline
\end{tabular}

Os resultados são semelhantes aos apresentados para o RCTR-C. As pequenas empresas continuam sendo maioria dentro do agrupamento $F R E R C F<100$, existindo, contudo, empresas de grande porte com essa característica, o que não ocorria com o primeiro seguro. Considerando-se, novamente, apenas as pequenas empresas, observa-se que há uma pequena inversão em relação ao RCTR-C. Naquele caso, as pequenas empresas que sempre utilizavam o seguro eram maioria (63\%). No caso do RCF-DC, a diferença entre os dois grupos é relativamente menor, com uma ligeira predominância, 
inclusive, de empresas com $F R E R C F<100$ : $45 \%$ das pequenas empresas afirmaram sempre utilizar o RCF-DC.

As diferenças entre as demais variáveis comparativas seguem a mesma tendência que o seguro RCTR-C, sendo contudo menos significativas, provavelmente pelo fato de haver uma maior distribuição das empresas nos dois agrupamentos.

Algumas colocações referentes à variável $\$ R C F D C$ são necessárias. Assim como no caso do seguro RCTR-C, praticamente não houve diferença para essa variável entre os dois agrupamentos. É interessante, porém, que se compare as informações dessas variáveis entre os dois tipos de seguros, ou seja, comparar $\$ R C T R C$ com $\$ R C F D C$. Para tanto, utiliza-se uma matriz comparativa (vide Figura 25), assim como procedido anteriormente em outras comparações.

\section{$\$ R C T R C$}

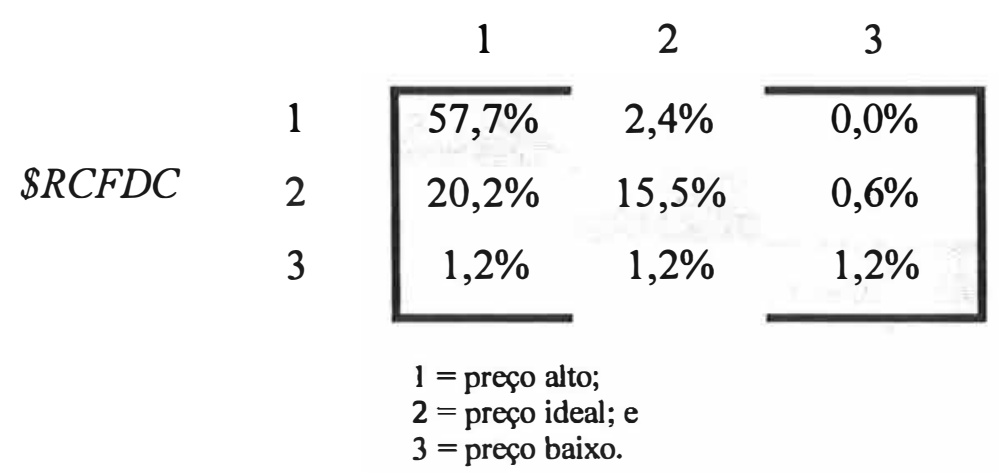

Figura 25: Matriz Comparativa $\$ R C T R C \times$ x $\$ R C F C$ (impressão sobre os preços dos seguros RCTR-C e RCF-DC, respectivamente): participação das empresas conforme resposta apresentada

A primeira informação relevante é a de que $57,7 \%$ das empresas amostradas julgam os dois seguros como "caros", ou seja, com valor elevado. Essa é a categoria dominante. Outra categoria que se sobressai é aquela que considera o preço do RCTR-C ideal, e o do RCF-DC elevado, sendo que nessa situação encontram-se $20,2 \%$ das empresas. 
O mais importante nessa comparação é identificar qual dos seguros é considerado o "mais caro". Uma simples verificação da matriz comparativa indica que o RCF-DC deve ocupar essa posição. A utilização de um teste não-paramétrico poderia confirmar esse fato; contudo, a diferença é tão evidente que o mesmo foi considerado dispensável. Dentre as 168 empresas estudadas, 43 apresentaram valores diferentes entre as variáveis, sendo que dessas, 38 consideram o seguro RCF-DC mais "caro" que o RCTR-C (terço inferior da matriz). Entretanto, mesmo que essa diferença exista, deve-se considerar que, para a maioria das empresas $(74,4 \%)$, os dois seguros são avaliados igualmente quanto à percepção de seu valor.

Outra variável que merece atenção especial é a NOTRCF. Quando comparada com as notas do RCTR-C, percebe-se - na Tabela 44 - que há uma diferença considerável, principalmente nos casos de frequências menores que 100. As Figuras $26 \mathrm{e}$ 27 ilustram as distribuições das empresas conforme as variáveis NOTRCT e NOTRCF, respectivamente. A Tabela 45, por sua vez, traz as médias e os desvios padrão dessas variáveis.

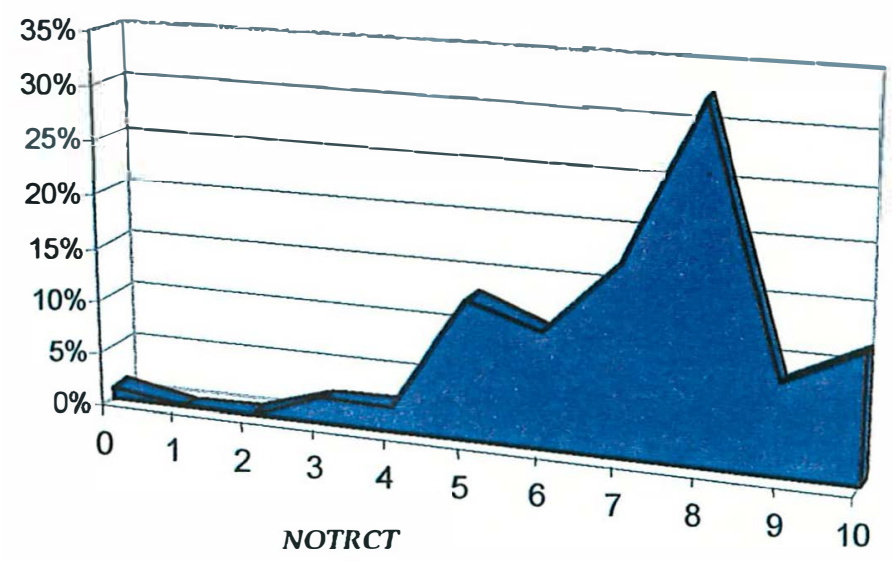

Figura 26. Distribuição das empresas da amostra segundo a variável NOTCRT (nota atribuída ao seguro RCTR-C). 


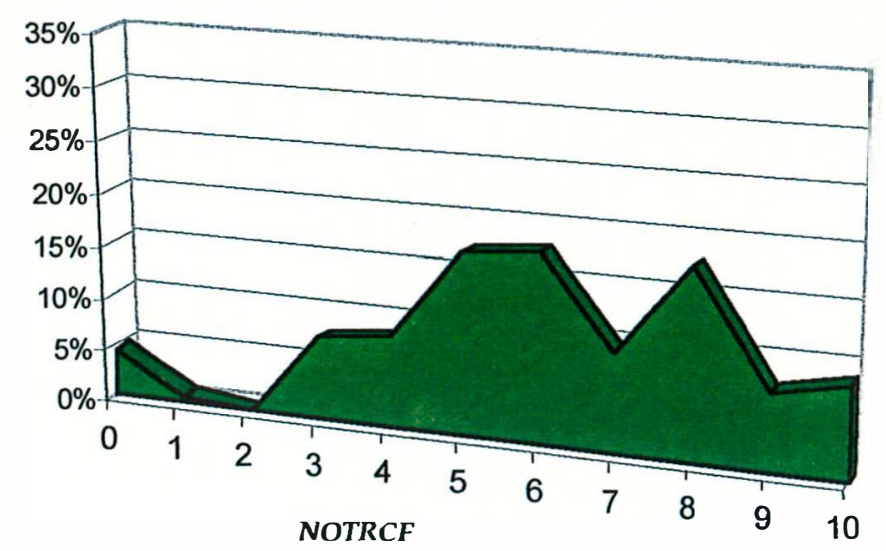

Figura 27. Distribuição das empresas da amostra segundo a variável NOTCRF (nota atribuída ao seguro RCF-DC).

Tabela 45. Média e Desvio Padrão das variáveis NOTRCT e NOTRCF (notas atribuídas aos seguros RCTR-C e RCF-DC, respectivamente).

\begin{tabular}{ccc}
\hline Parâmetros & NOTRCT & NOTRCF \\
\hline Média & 7,2 & 6,1 \\
Desvio Padrão & 1,9 & 2,4 \\
\hline
\end{tabular}

Ao que tudo indica, os transportadores estão mais satisfeitos com o RCTR-C que com o RCF-DC, vista a média das notas atribuídas ao primeiro seguro ser superior à das atribuídas ao segundo. Um teste não-paramétrico é utilizado para testar essa hipótese: o "Teste de Sinais", apresentado anteriormente.

A variável NOTRCT é maior que a NOTRCF para 55 empresas, portanto, $\mathrm{Y}=55$. Em 68 observações as variáveis diferem, isto é $n=68$. Com esses parâmetros, obtém-se um $\mathrm{Z}$ calculado igual a 4,97. Como $\mathrm{Z}_{(1 \%)}=2,33$ e, consequentemente $\mathrm{Z}>\mathrm{Z}_{(1 \%)}$, rejeitamos a hipótese de que as notas são iguais, aceitando-se a hipótese de que a NOTRCT é maior que a NOTRCF, com um alto grau de significância.

Um outro assunto a ser tratado na verificação desta última hipótese está relacionado aos procedimentos de gerência de risco adotados pelas empresas. É dada ênfase para aqueles utilizados no tratamento do risco de roubo e desvio de carga. 
Como comentado no início deste item, a escolha pelo "não seguro" faz parte da concepção de gerência de risco, que implicaria em uma decisão voluntária por parte dos indivíduos ("desinteresse" pelo seguro).

É bastante comum, nos estudos de demanda por determinado bem, a consideração dos seus complementares e substitutos.

Portanto, tentar-se-á, a partir deste momento, a identificação do comportamento das empresas em relação à demanda por todos esses bens, sejam eles complementares, substitutos, ou ainda, o próprio seguro de carga (no caso o RCF-DC, por estar-se tratando do risco de roubo de cargas).

Uma informação é fundamental nesse sentido: PROCED, obtida através de uma questão na qual é fornecida aos transportadores uma série de procedimentos de gerência de risco, e solicitado que os mesmos fossem ordenados de acordo com a importância dada pela empresa para tratar o risco de roubo de cargas. Os procedimentos propostos, suas respectivas siglas - que serão utilizadas daqui para frente - e as categorias de Gerência de Risco que se enquadram, constam na Tabela 46.

Tabela 46. Procedimentos de gerência de risco considerados, suas siglas e as categorias em que se enquadram.

\begin{tabular}{|c|c|c|}
\hline Procedimento & Sigla & $\begin{array}{c}\text { Categoria de Gerência de } \\
\text { Risco }\end{array}$ \\
\hline Utilização de seguro para a carga & seguro & $\begin{array}{c}\text { Transferir o Risco: Com } \\
\text { Seguro (CS) }\end{array}$ \\
\hline Fracionamento da carga em volumes menores & fracio & Reduzir o Risco (RR) \\
\hline Utilização de escolta para a frota & escolt & Reduzir o Risco (RR) \\
\hline Treinamento dos motoristas para evitar o roubo & treina & Reduzir o Risco (RR) \\
\hline Equipar os veículos com rastreadores & rastre & Reduzir o Risco (RR) \\
\hline Não transportar cargas de valor elevado & ñtrans & Anular o Risco (AR) \\
\hline Outro & (aberto) & (aberto) \\
\hline
\end{tabular}

Além das categorias dispostas nessa tabela. há outras três que também são consideradas: 
- Reter o Risco: não-seguro (NS);

- Reter o Risco: auto-seguro (AS); e

- Transferir o Risco: sem seguro (SS).

$\mathrm{O}$ "não-seguro" será avaliado através da variável $F R E R C F$, que procura captar a frequência com que os transportadores utilizam o seguro. Nos casos onde $F R E R C F<100$, ocorre - de certa forma - uma retenção do risco por parte da empresa.

Em relação às outras duas categorias, torna-se bastante difícil a sua identificação quantitativa. É importante ressaltar também que, em vista dessa dificuldade de identificação, os casos de "retenção de risco: não seguro" passam a ficar superestimados, pois aquelas situações onde poderiam estar ocorrendo um auto-seguro (AS) ou uma transferência sem seguro (SS), passam a ser consideradas como "não-seguro".

A metodologia utilizada para a quantificação da importância dos diferentes procedimentos listados na Tabela 46 é a seguinte: as colocações (posições) foram ponderadas, sendo que o procedimento na primeira posição recebe nota (máxima) 100, o da segunda, nota 90, e assim sucessivamente até a sétima posição, que recebe nota (mínima) 40. Essas notas - de todas as empresas - foram somadas dentro de cada procedimento (resultando em pontos parciais) e divididas pela soma total de todos os procedimentos.

Para a quantificação da retenção do risco $(F R E R C F<100)$, estipulou-se o critério de considerar como $1^{\mathrm{a}}$ posição, casos $\operatorname{com} F R E R C F=0 ; 2^{\mathrm{a}}$ posição, casos com $F R E R C F=20 ; 3^{\mathrm{a}}$ posição, casos com $F R E R C F=40$, e assim sucessivamente, até os casos com $F R E R C F=80$, para os quais foi atribuída a $5^{\mathrm{a}}$ posição.

Essa metodologia resulta em um índice que foi denominado de "Índice de Importância" (I.I.) dos procedimentos de gerência de risco para o tratamento do risco de roubo de cargas. A Tabela 47 traz o número de colocações dos procedimentos, os pontos parciais e os Índices de Importância para todas as empresas da amostra ${ }^{40}$.

${ }^{40}$ Não são consideradas as empresas de transporte de carga própria (CLASSE=TCP). 
Tabela 47. Número de colocações, pontos parciais e Índices de Importância (I.I.) dos procedimentos de gerência de risco.

\begin{tabular}{|c|c|c|c|c|c|c|c|c|c|}
\hline \multicolumn{8}{|c|}{$\mathrm{N}^{\circ}$ de colocações (posições) } & \multirow[b]{2}{*}{ Pontos Parciais } & \multirow{2}{*}{$\begin{array}{c}\text { Índice de } \\
\text { Importância } \\
\text { (I.I.) }\end{array}$} \\
\hline Procedimentos & $1^{a}$ & $2^{\mathrm{a}}$ & $3^{\mathrm{a}}$ & $4^{\mathrm{a}}$ & $5^{\mathrm{a}}$ & $6^{\mathrm{a}}$ & $7^{\mathrm{a}}$ & & \\
\hline seguro $(\mathbf{C S})$ & 112 & 11 & 6 & 2 & 0 & 0 & 0 & 12810 & $24,49 \%$ \\
\hline fracio $(\mathbf{R R})$ & 5 & 14 & 21 & 14 & 16 & 6 & 0 & 5680 & $10,86 \%$ \\
\hline escolt (RR) & 2 & 12 & 18 & 19 & 12 & 14 & 0 & 5470 & $10,46 \%$ \\
\hline treina $(\mathbf{R R})$ & 22 & 50 & 19 & 18 & 3 & 1 & 0 & 9710 & $18,56 \%$ \\
\hline rastre $(\mathbf{R R})$ & 6 & 19 & 18 & 10 & 13 & 6 & 0 & 5530 & $10,57 \%$ \\
\hline ñtrans (AR) & 14 & 17 & 13 & 6 & 10 & 20 & 2 & 6070 & $11,60 \%$ \\
\hline$\tilde{\text { nnoite }}{ }^{1}$ (outro) $(\mathbf{R R})$ & 1 & 0 & 0 & 0 & 0 & 0 & 0 & 100 & $0,19 \%$ \\
\hline consmo $^{2}$ (outro) (RR) & 0 & 2 & 1 & 1 & 0 & 0 & 0 & 330 & $0,63 \%$ \\
\hline $\operatorname{comboi}^{3}$ (outro) (RR) & 0 & 0 & 1 & 1 & 0 & 0 & 0 & 150 & $0,29 \%$ \\
\hline retenç $^{4}(\mathrm{NS})$ & 51 & 5 & 2 & 3 & 9 & 0 & 0 & 6460 & $12,35 \%$ \\
\hline & os & Totais & & & & & & 52310 & $100,00 \%$ \\
\hline
\end{tabular}

Para melhor visualizar os Índices de Importância, as informações da Tabela 47 são colocadas na Figura 28. 


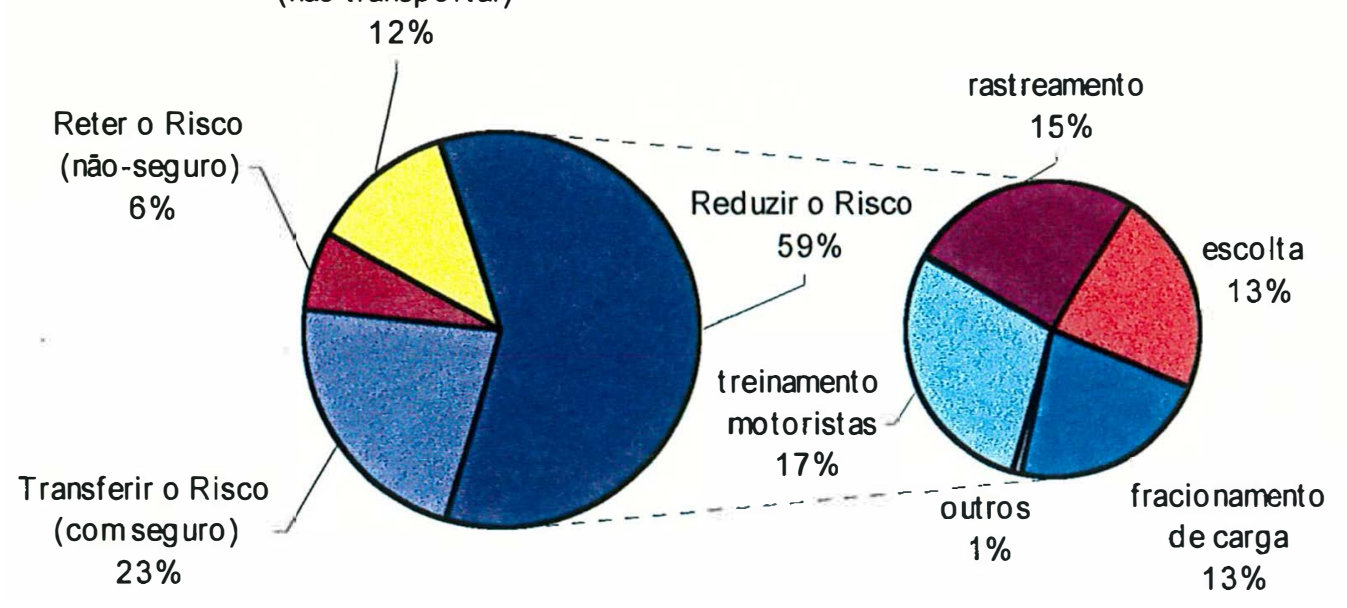

Figura 28. Índices de Importância dos diferentes procedimentos de gerência de risco.

É importante ressaltar que o Índice de Importância (I.I.) não mede a frequência com que as empresas utilizam os diferentes procedimentos, muito menos a participação das empresas que utilizam um ou outro procedimento. É um índice criado com o objetivo de ilustrar - como o próprio nome sugere - a avaliação dos transportadores em relação à importância dos procedimentos utilizados pelos mesmos.

Na Figura 28 são ilustrados os procedimentos agrupados em suas respectivas categorias de gerência de risco: transferir o risco: com seguro; reter o risco: não-seguro; anular o risco; e RR reduzir o risco.

Sendo assim, percebe-se que o seguro de carga (transferência do risco com seguro - CS) é a ferramenta considerada mais importante por parte das empresas da amostra, apresentando um I.I. $=24 \%$. Em segundo lugar, aparece o treinamento de motoristas para evitar o roubo, com um I.I. $=19 \%$ (inserido na categoria RR) Os procedimentos de não-seguro (retenção do risco com não-seguro - NS) e de não transporte de mercadorias de alto valor (anulação do risco - AR) aparecem em terceiro lugar com I.I. $=12 \%$. Em quarto lugar, surgem a utilização de equipamentos de rastreamento (rastre) e o fracionamento da carga (fracio), com I.I. $=11 \%$ (ambos na categoria RR). Em seguida situa-se, com I.I. $=9 \%$, a utilização de escolta (escolt, também na categoria RR). A categoria "outros", com I.I. $=1 \%$, refere-se aos outros procedimentos 
não propostos aos entrevistados, mas apontados pelos mesmos. São eles: não viajar à noite, consultar a idoneidade de novos motoristas e transportar em comboio.

Uma forma de explorar melhor essas informações é através da consideração do tamanho das empresas, agrupadas - conforme a variável TFROTA - em pequenas, médias e grandes, como vem sendo feito até o momento. Na Tabela 48, são expostos os Índices de Importância, de acordo com o tamanho das empresas.

Tabela 48. Índices de Importância conforme o tamanho das empresas.

\begin{tabular}{|c|c|c|c|c|c|c|}
\hline \multirow{3}{*}{ Procedimentos } & \multicolumn{6}{|c|}{ Índices de Importância (II), segundo o porte das empresas } \\
\hline & \multicolumn{2}{|c|}{ Pequenas } & \multicolumn{2}{|c|}{ Médias } & \multicolumn{2}{|c|}{ Grandes } \\
\hline & II & Posição & II & Posição & II & Posição \\
\hline seguro (CS) & $22,04 \%$ & $1^{\mathrm{a}}$ & $29,16 \%$ & $1^{\mathrm{a}}$ & $22,19 \%$ & $1^{\mathrm{a}}$ \\
\hline fracio $(\mathbf{R R})$ & $10,38 \%$ & $5^{\mathrm{a}}$ & $9,74 \%$ & $5^{a}$ & $12,81 \%$ & $5^{\mathrm{a}}$ \\
\hline escolt $(\mathbf{R R})$ & $7,70 \%$ & $7^{\mathrm{a}}$ & $11,05 \%$ & $3^{\mathrm{a}}$ & $13,32 \%$ & $4^{\mathrm{a}}$ \\
\hline treina $(\mathbf{R R})$ & $18,57 \%$ & $3^{\mathrm{a}}$ & $19,07 \%$ & $2^{\mathrm{a}}$ & $17,09 \%$ & $2^{\mathrm{a}}$ \\
\hline rastre $(\mathbf{R} \mathbf{R})$ & $8,56 \%$ & $6^{\mathrm{a}}$ & $9,58 \%$ & $6^{\mathrm{a}}$ & $15,33 \%$ & $3^{\mathrm{a}}$ \\
\hline ñtrans (AR) & $11,77 \%$ & $4^{\mathrm{a}}$ & $10,80 \%$ & $4^{\mathrm{a}}$ & $12,31 \%$ & $6^{\mathrm{a}}$ \\
\hline$\tilde{n}$ noite ${ }^{l}$ (outro) (RR) & $0,54 \%$ & $9^{a}$ & $0,00 \%$ & - & $0,00 \%$ & - \\
\hline consmo $^{2}$ (outro) (RR) & $0,86 \%$ & $8^{a}$ & $0,86 \%$ & $8^{a}$ & $0,00 \%$ & - \\
\hline comboi $^{3}$ (outro) (RR) & $0,00 \%$ & $10^{\mathrm{a}}$ & $0,41 \%$ & $9^{a}$ & $0,59 \%$ & $8^{a}$ \\
\hline $\operatorname{retenc}^{4}(\mathbf{N S})$ & $19,58 \%$ & $2^{a}$ & $9,33 \%$ & $7^{\mathrm{a}}$ & $6,37 \%$ & $7^{\mathrm{a}}$ \\
\hline
\end{tabular}

T'Não transportar à noite; ' ${ }^{\top}$ Consultar idoneidade dos motoristas; ' Transportar em comboio (veículos agregados);

${ }^{4}$ Retenção do Risco através de não seguro.

O seguro de carga continua sendo considerado o mais importante para todos os tamanhos de empresa, principalmente para as de médio porte, onde o seu I.I. foi de quase $30 \%$.

A variável retenç (NS) - consequência de uma $F R E R C F<100$ - apresentou-se mais relevante para as empresas de pequeno porte, ocupando a segunda posição com I.I. $=19,58 \%$, bastante próximo, portanto, do seguro. Essa informação vai ao encontro do que já foi exposto: é no grupo das pequenas empresas em que o seguro de roubo (RCF- 
DC) é menos utilizado. Observa-se também - ainda em relação à retenç - que esse procedimento vai perdendo importância à medida que aumenta o tamanho das empresas, sendo o I.I. para as médias e grandes empresas iguais a 9,33\% e 6,37\%, respectivamente.

Como já mencionado, o treinamento dos motoristas (treina) é outro procedimento considerado bastante importante por parte das empresas, variando relativamente pouco (entre 17\% e 19\%) conforme o tamanho das mesmas.

A utilização de rastreadores (rastre) e escolta (escolt) - por serem procedimentos de custos relativamente elevados - é mais comum em empresas de grande porte, como pode ser percebido. Esses são "bens" que, a princípio, deveriam ser substitutos ao seguro pois sua adoção poderia reduzir sensivelmente o risco. Contudo, isso não ocorre, pois a organização do crime muitas vezes se sobressai sobre o mesmo. Na realidade, os bens em questão apresentam mais caráter de complementariedade, mesmo porque, em muitas situações, são condição sine qua non para a utilização do seguro.

O procedimento de anular o risco, ou seja, não transportar mercadorias de valor elevado, não apresentou muita variação entre os grupos de empresas, tendo variado aproximadamente entre 11 e $12 \%$. É um procedimento de suma importância, mas que apresenta a restrição de ter um certo limite, caso contrário significaria o simples cancelamento das atividades de um transportador. Esse comportamento também contribui para a seleção de transportadores para a operação com determinadas cargas, como explicado anteriormente. Portanto, a dita seleção também surge do lado do transportador e não apenas do embarcador.

\subsection{Modelo de Resposta Qualitativa: Aplicação na Demanda por Seguro de}

\section{Carga}

Neste item, são utilizadas as informações obtidas junto aos transportadores para a obtenção de um modelo de demanda para os seguros de responsabilidade civil para cargas.

Como observado no item 3.2 , os modelos de resposta qualitativa podem ser utilizados para estudos de demanda por bens, inclusive seguros. Uma exigência natural 
desses modelos, como também foi comentado, refere-se à necessidade de dados para sua estimação. Vista a não existência de dados sistemáticos para aplicação neste trabalho, optou-se por uma metodologia baseada na aplicação de questionários junto aos agentes.

Porém, essa metodologia utilizada apresenta certa limitação no que concerne à precisão das informações obtidas, o que pode dificultar o ajuste de modelos econométricos. Por esse motivo, procedeu-se com análises fundamentadas em estatística descritiva.

Mesmo com a existência dessa limitação quanto à precisão dos dados, um modelo econométrico foi ajustado com o objetivo de permitir uma análise do efeito conjunto das variáveis sobre a demanda por seguro, bem como para verificar a consistência dos resultados obtidos com as análises estatísticas mencionadas no parágrafo anterior.

São estimados dois modelos de demanda: um para o seguro de Responsabilidade Civil do Transportador Rodoviário de Carga (RCTR-C) e outro para o de Responsabilidade Civil do Transportador Rodoviário por Desaparecimento de Carga (RCF-DC).

As variáveis dependentes são representadas pelas variáveis FRERCT e FRERCF, que podem assumir dois valores: 0 (zero) para empresas que não utilizam os seguros RCTR-C e RCF-DC, respectivamente; e 1 (um) para aquelas que utilizam os seguros em questão, mesmo que não que isso não ocorra com uma frequência de $100 \%$. Portanto:

$$
\begin{aligned}
& \mathrm{Y}=0 \text { se FRERCT (ou FRERCF })=0 \\
& \mathrm{Y}=1 \text { se } F R E R C T(\text { ou } F R E R C F)>0
\end{aligned}
$$

Talvez fosse mais interessante admitir mais de dois valores para as variáveis dependentes, como, por exemplo: 0 (zero) para FRERCT=0; 1 (um) para $0<F R E R C T<100$, e 2 (dois) para $F R E R C T=100$. Porém, o número reduzido de observações, bem como a limitação - já mencionada - na precisão dos dados, acabam por dificultar a estimação desses modelos. Em vista disso, opta-se pela escolha de apenas 
dois valores para aquelas variáveis, mesmo porque isso facilita a captação dos efeitos das variáveis explicativas por parte do modelo econométrico.

As variáveis explicativas, por sua vez, são as seguintes:

- LOCALG (Localização Geográfica): variável tipo dummy, assume valor 0 (zero) para empresas com matriz em todos os Estados brasileiros, à exceção dos Estados de São Paulo e Rio de Janeiro. Assume valor 1 (um) para aquelas empresas com matriz nesses dois Estados.

- TCARGA (Tipo de Carga): variável tipo dummy, assume valor 0 (zero) para empresas que não transportam cargas denominadas "cargas secas", e valor 1 (um) para empresas que operam com esse tipo de carga.

- FUNDAÇ (Idade da Empresa): assume valores contidos na Tabela 14 do item 3.1 (Descrição das variáveis). É uma proxy para a experiência da empresa.

- TFROTA (Tamanho da Frota): assume valores contidos na Tabela 15 do item 3.1. É uma proxy para o tamanho da empresa.

- IFROTA (Idade da Frota): assume valores contidos na Tabela 16 do item 3.1.

- NOTRCT e NOTRCF (Nota para a eficiência dos seguros RCTR-C e RCFDC, respectivamente): assumem valores de 0 (zero) a 10 (dez). É uma proxy para a satisfação das empresas em relação aos seguros.

- NROUBO (Número de roubos sofridos nos últimos cinco anos): assume valores contidos na Tabela 18, do item 3.1.

- OFERCF (Problema com oferta do RCF-DC): no modelo será considerada como variável tipo dummy. Assume valor 0 (zero) para os casos de $O F E R C F=1,2$, ou 3 (empresas que já tiveram pelo menos um problema de oferta); e 1 (um) para os casos de $O F E R C F=4$ (empresas que nunca tiveram problema de oferta).

- FRERCT (Frequência com que as empresas utilizam o seguro RCTR-C): assume valores contidos na Tabela 27 do item 3.1. 
Para o modelo do RCTR-C, são utilizadas as variáveis: LOCALG, TCARGA, FUNDAÇ, TFROTA, IFROTA e NOTRCT. No caso do RCF-DC, são utilizadas essas mesmas variáveis, à exceção da NOTRCT, que é substituída pela NOTRCF. Além dessa modificação, ainda são utilizadas para o RCF-DC: NROUBO, OFERCF e FRERCT.

Os resultados da estimação dos dois modelos são apresentados na Tabela 49. 
Tabela 49. Equações de demanda por seguros de responsabilidade civil de transportadores rodoviários de carga. Informações da média, coeficiente estimado (em negrito), e teste-t (entre parênteses).

\begin{tabular}{|c|c|c|}
\hline Variáveis & RCTR-C & RCF-DC \\
\hline \multirow{3}{*}{$L O C A L G$} & 0,3448 & 0,3373 \\
\hline & 1,7699 & 1,4490 \\
\hline & $(1,782)^{*}$ & $(2,263)^{* *}$ \\
\hline \multirow{3}{*}{ TCARGA } & 0,7759 & 0,7831 \\
\hline & $-0,2880$ & 0,0159 \\
\hline & $(-0,352)$ & $(0,034)$ \\
\hline \multirow{3}{*}{ FUNDAÇ } & 17,71 & 17,87 \\
\hline & $-0,0516$ & $-0,0157$ \\
\hline & $(-1,412)$ & $(-0,632)$ \\
\hline \multirow{3}{*}{ TFROTA } & 75,41 & 76,84 \\
\hline & 0,1059 & $-0,0055$ \\
\hline & $(2,475)^{* * *}$ & $(-1,824)^{*}$ \\
\hline \multirow{3}{*}{ IFROTA } & 7,925 & 7,831 \\
\hline & $-0,1798$ & $-0,1383$ \\
\hline & $(-1,876)^{*}$ & $(-2,328)^{*}$ \\
\hline \multirow{3}{*}{ NOTRCT } & 6,974 & - \\
\hline & 0,4607 & - \\
\hline & $(2,827)^{* * *}$ & - \\
\hline \multirow{3}{*}{ NOTRCF } & - & 5,795 \\
\hline & - & 0,1905 \\
\hline & - & $(1,969)^{* *}$ \\
\hline \multirow{3}{*}{ NROUBO } & - & 5,030 \\
\hline & - & 0,2298 \\
\hline & - & $(2,464)^{* * *}$ \\
\hline \multirow{3}{*}{ OFERCF } & - & 0,633 \\
\hline & - & $-0,1574$ \\
\hline & - & $(-0,357)$ \\
\hline \multirow{3}{*}{ FRERCT } & - & 87,95 \\
\hline & - & 0,0125 \\
\hline & - & $(2,131)^{* *}$ \\
\hline Teste da razão de verossimilhança & $39,22496 * * *$ & $50,06108^{* *}$ \\
\hline $\mathrm{N}^{\circ}$ de observações & 174 & 166 \\
\hline
\end{tabular}


Para o ajuste do modelo do RCTR-C, foram utilizadas 174 observações, enquanto que para o RCF-DC, foram 166 observações. Ambos apresentaram um alto nível de significância (foram significativos a $1 \%$ ), conferindo, consequentemente, credibilidade aos resultados obtidos.

As variáveis que apresentaram influência na demanda por RCTR-C foram a LOCALG, a TFROTA, a IFROTA e NOTRCT, com destaque para TFROTA e NOTRCT, significativas a $1 \%$ (essa última, inclusive, com um grau de significância ainda mais elevado que a TFROTA).

No modelo do RCF-DC, as variáveis LOCALG, TFROTA, IFROTA, NOTRCF, $N R O U B O$, e FRERCF apresentaram influência significativa na sua demanda. A variável NROUBO apresentou um maior nível de significância (1\%).

Para os dois modelos, as variáveis TCARGA e FUNDAÇ não foram significativas.

O resultado da variável TCARGA é um exemplo do que vem sendo comentado sobre a precisão das informações e também sobre a diversidade do produto de transporte. Além desse aspecto ligado à natureza da atividade, é bastante difícil representar através de uma variável os diversos tipos de cargas existentes, mesmo porque, não é uma informação numérica. O ideal seria a estimação de modelos de demanda dentro de um determinado tipo de carga. Como isso não foi possível, optou-se pela simplificação através de uma variável dummy, que separa empresas que transportam ou não cargas secas (que são as mais visadas para o roubo).

A variável $F U N D A C \zeta$, por sua vez, não apresentou uma relação definida com a demanda por seguro, pelo fato de ser a idade de uma empresa outro aspecto bastante heterogêneo na atividade. Há uma grande entrada e saída de empresas no setor, como conclui Castro (1988). Além disso, há muitas fusões, aquisições e desmembramentos de empresas, tendência essa reforçada nos últimos anos. Isso faz com que a informação de experiência - obtida pelo tempo na atividade - fique prejudicada.

A variável IFROTA (Idade da Frota) apresentou comportamento semelhante para os dois seguros, ainda que com um nível de significância não muito elevado (10\%). O sinal dos coeficientes estimados foram negativos tanto para o RCTR-C quanto para o 
RCF-DC, ou seja, à medida que a frota torna-se "mais velha", a probabilidade das empresas utilizarem essas coberturas tende a diminuir.

Observa-se, de uma forma geral, que os resultados obtidos através das análises estatísticas são confirmados pelos modelos econométricos.

A localização das empresas nos Estados de SP e RJ apresentou influência sobre a demanda pelos seguros, com maior significância para o RCF-DC. Como foi visto, essas são regiões onde há uma maior incidência de roubos de cargas, e que isso deve estimular os transportadores a utilizarem mais os seguros de responsabilidade civil, inclusive o RCTR-C. Além disso, são regiões onde as condições de tráfego - mais intenso - devem estar mais sujeitas aos demais riscos da atividade, como o de tombamento, por exemplo. O sinal do coeficiente de $L O C A L G$ sugere essa influência positiva sobre a probabilidade das empresas utilizarem os seguros.

Attanasi \& Karlinger (1979), ao estudarem a demanda por seguro contra enchente, identificaram a capacidade dos indivíduos em captar a influência de determinada região geográfica no risco de ocorrência de determinado evento. Os autores observaram que as pessoas residentes em regiões com probabilidade de enchentes mais severas utilizavam mais seguro para suas casas do que aquelas onde esse risco não era tão grande ${ }_{i}$ É um resultado que vai ao encontro do observado neste estudo de demanda por seguro de carga.

O tamanho da empresa - representado pela variável TFROTA - foi outra característica já analisada anteriormente (item 4.3.4), sendo que os resultados também estão condizentes com os já verificados. A TFROTA apresentou maior influência sobre a demanda do RCTR-C que sobre a do RCF-DC. Para o primeiro seguro, a relação foi claramente positiva, indicando que empresas maiores tendem a utilizar mais o RCTR-C. Já para o segundo, a relação foi negativa, porém com um coeficiente de valor bastante reduzido, indicando uma influência negativa relativamente baixa.

A variável TFROTA é aquela que mais se aproxima do atributo "riqueza" (wealth) largamente utilizado nos estudos de comportamento diante do risco, inclusive a demanda por seguro. A relação entre a demanda por seguro e a "riqueza" dos indivíduos 
fornece a informação do "tipo" do bem "seguro", ou seja, se o mesmo é um bem inferior ou superior.

Quando a demanda por seguro diminui à medida que aumenta a renda dos indivíduos, o seguro é considerado como um bem inferior. Já quando a demanda por seguro aumenta à medida que a renda também aumenta, o seguro é considerado um bem superior. De uma maneira geral, no Brasil o seguro vem sendo considerado um bem superior (Conjuntura Econômica, 1998), porém não há um consenso na literatura a esse respeito, sendo que cada tipo de seguro deve ser analisado individualmente para se concluir a esse respeito.

Cicchetti \& Dubin (1994), estudando seguro para problemas em linhas telefônicas, concluíram que o mesmo era um bem inferior, pois as pessoas de renda mais elevada tendiam a demandá-lo menos. Friedman (1974) chegou à conclusão semelhante estudando a demanda por planos de saúde. As famílias com salários mais elevados eram menos aversas ao risco que aquelas menos favorecidas e, consequentemente, demandavam menos seguros de saúde que essas últimas.

Considerando-se que o atributo "tamanho da frota que opera" seja adequado para representar a "riqueza" de uma empresa transportadora, o resultado do modelo de escolha discreta, bem como as análises estatísticas, mostraram que o seguro RCTR-C é um bem do tipo superior, pois as empresas que operam frotas maiores tendem a utilizálo mais frequentemente que aquelas com frotas menores.

O seguro RCF-DC, por sua vez, mostrou-se - através do modelo - um bem inferior pois o coeficiente de TFROTA apresentou sinal negativo. Na realidade, o tamanho de uma empresa, por si só, não significa que a mesma utilizaria mais o RCFDC. Há muitos outros fatores influenciando na demanda pelo seguro de roubo, tal como o tipo de carga a ser transportada. Toma-se o caso de uma grande empresa transportadora de granéis líquidos (óleo de soja, por exemplo). É provável que a carga seja pouco visada pelos assaltantes, o que desestimularia a utilização do RCF-DC. O inverso pode ser verdadeiro, como no caso de uma pequena empresa transportadora de valores que depende fundamentalmente do seguro RCF-DC por operar com um tipo de mercadoria bastante visada: dinheiro. 
Portanto, essa interação entre variáveis - no exemplo: TCARGA e TFROTA - é difícil de ser modelada e/ou captada pelos modelos econométricos, o que dificulta também, a conclusão sobre o "tipo" de bem que caracteriza o seguro RCF-DC.

Duas variáveis que apresentaram forte influência sobre a demanda pelos seguros RCTR-C e RCF-DC foram as notas atribuídas para sua eficiência: NOTRCT e NOTRCF, respectivamente. Ambas - utilizadas como proxy para a impressão das empresas em relação à eficiência dos seguros - apresentaram relação positiva e foram mais significativas do que as outras variáveis nas suas respectivas equações. Nenhum dos trabalhos de demanda por seguro consultados consideraram atributos dessa natureza na sua modelagem. Para o presente estudo isso era fundamental, uma vez que os eventos de roubo de cargas vêm gerando uma série de problemas relacionados à oferta e à demanda pelos seguros de carga.

Dentre as três variáveis exclusivas do modelo do RCF-DC - NROUBO, FRERCT e $O F E R C F$ - apenas essa última não foi significativa.

A NROUBO e a FRERCT apresentaram coeficientes com sinal esperado (positivo), indicando que um aumento no número de roubos sofridos e na frequência com que as empresas utilizam o RCTR-C, tendem a aumentar a probabilidade das mesmas em utilizar o seguro RCF-DC.

A variável $N R O U B O$ influencia positivamente a probabilidade de aumento na utilização do RCF-DC. Isso é algo bastante comum na demanda por seguros em geral, ou seja, a experiência com a ocorrência de sinistros é um dos motivos que leva os indivíduos a procurarem os seguros, não sendo diferente para os seguros de cargas.

Esse resultado da NROUBO pode sugerir uma outra informação importante. Como foi abordado no item 4.2, deve haver uma relação não-unívoca entre tamanho da empresa e número de roubos sofridos. Essa relação parece existir no sentido de que empresas com elevado $N R O U B O$ apresentam, consequentemente, um elevado valor para a variável TFROTA. O inverso não é verdadeiro, ou seja, empresas com elevado tamanho de frota não necessariamente sofreram um elevado número de roubos, pois caso isso fosse verdade. deveria existir também uma influência positiva do tamanho da 
empresa na demanda pelo RCF-DC, e isso não ocorreu, conforme mencionado anteriormente.

A variável FRERCT, por sua vez, apresenta um resultado esperado e não menos relevante. O sinal positivo de seu coeficiente indica que com o aumento na frequência com que as empresas utilizam o RCTR-C, aumenta a demanda pelo outro seguro, o RCF-DC. Aspectos nesse sentido foram abordados através de uma Matriz Comparativa no item 4.3.2. Em síntese, esses resultados sugerem que há uma forte relação entre as demandas pelos dois seguros.

Finalmente, a variável OFERCF deve ser comentada. Como já foi abordado, muitas empresas alegam que não se deparam com problemas de oferta do RCF-DC por nunca o terem procurado $(F R E R C F=0)$. Portanto, para análises nesse sentido, faz-se importante a separação das observações segundo alguns critérios, como foi procedido no item 4.3.2. O comportamento da variável no modelo econométrico acabou não apresentando significância.

Esses foram os principais resultados obtidos da utilização de modelos de escolha discreta para o estudo da demanda por seguros de responsabilidade civil de transportadores. Percebe-se que muitas variáveis foram deixadas de lado quando da estimação dos referidos modelos. Isso foi uma opção justificada pela existência de um número relativamente reduzido de observações, o que resultaria em problemas relacionados aos graus de liberdade das equações. Foram utilizadas, consequentemente, apenas as variáveis consideradas mais relevantes.

De qualquer forma, pode-se considerar que os resultados foram bastantes satisfatórios, mesmo porque confirmaram aqueles obtidos com as análises conduzidas no item 4.3. 


\section{CONCLUSÕES}

O presente trabalho propôs-se a estudar os seguros de carga para o transporte rodoviário, enfatizando sua demanda por parte dos transportadores. O risco de roubo de cargas mereceu atenção especial nesse contexto, uma vez que se trata de um sério problema ao desempenho da atividade na atualidade.

Para orientar as análises, foram propostas - e testadas - quatro hipóteses básicas, sob as quais procurou-se agrupar os principais problemas relacionados à demanda pelos seguros mencionados.

De uma maneira geral, nenhuma das hipóteses pôde ser refutada, ou seja, as informações coletadas junto às empresas permitiram a identificação tanto de dificuldades dos transportadores para a obtenção de seguro, como de exigências impostas sobre os mesmos para essa utilização, passando por situações em que haveria dificuldades administrativas - falta de conhecimento - em assuntos relacionados aos seguros, e até mesmo ocasiões nas quais todas essas hipóteses poderiam estar ausentes simplesmente pelo fato de que a utilização de tais seguros não interessam a alguns transportadores.

As análises foram conduzidas a partir de dados obtidos diretamente de indivíduos e empresas, através de questionários ou por entrevistas pessoais. As técnicas de estatística descritiva foram fundamentais no desenvolvimento do trabalho.

A revisão de literatura sobre o assunto "demanda por seguro" revelou a utilização de modelos econométricos baseados em funções de utilidade esperada. Contudo, tais modelos são exigentes no que concerne à qualidade e quantidade de dados para sua estimação. Sendo assim, e em vista de que os dados levantados poderiam não apresentar uma precisão adequada, esses modelos foram comparados com os resultados obtidos através de análises elaboradas com a utilização de estatística descritiva.

Mesmo com a limitação dos dados, os modelos econométricos de escolha discreta apresentaram um ajuste satisfatório, além de ratificarem os resultados obtidos com as análises prévias. Sendo assim, foi possível identificar os principais motivos que 
levam ou não os transportadores a utilizarem os seguros de responsabilidade civil para cargas.

É importante ressaltar ainda que os seguros de transporte apresentam um complicador adicional quando comparado a outros tipos de seguros: a grande heterogeneidade de suas coberturas e taxas, o que dificulta sobremaneira a utilização dos modelos mencionados.

Especificamente em relação ao roubo de cargas, o surgimento relativamente recente desse problema no País, de uma forma ou de outra, está por trás de muitos dos problemas relacionados aos seguros de transporte de carga. E aqui surge uma primeira conclusão: o evento "roubo de cargas" está exigindo uma revisão no comportamento dos diversos setores relacionados à atividade.

Os transportadores, que são os primeiros a serem atingidos pelo problema, devem ser também os primeiros a reverem o seu comportamento. A utilização de "novos" procedimentos de gerência de risco, tais como rastreadores e escoltas - passam a ser fundamentais na operação de algumas cargas. O treinamento de motoristas, considerado um dos procedimentos mais importantes, torna-se condição fundamental para a atividade. $\mathrm{O}$ entendimento e manutenção de apólices de seguros ajustadas às reais necessidades das empresas é outra vertente que deve ser revista.

$\mathrm{Na}$ realidade, muitos transportadores já estão atentos a essas necessidades; contudo, ainda há muitos que devem atuar nesse sentido, sob pena de enfrentarem problemas relacionados à obtenção das coberturas necessárias para as cargas que operam.

Um outro ponto de suma importância, e que vem alimentando uma grande discussão entre embarcadores, transportadores e corretores/seguradores, é o entendimento e delimitação das responsabilidades sobre as cargas movimentadas.

Através de contatos com indivíduos ligados à atividade, percebeu-se que muitos não compreendem a definição das responsabilidades sobre as cargas, bem como apresentam dificuldade para entender as coberturas apresentadas pelos diferentes seguros e, consequentemente, avaliar a importância de utilizar aquele tipo de seguro mais adequado para determinada situação. 
Esses "ruídos" de informação são fruto, em grande parte, da linha tênue que pode separar a "negligência do transportador", dos casos de "força maior", em situações de roubo de cargas, ou seja, pode ser tarefa bastante complexa diferenciar casos onde o sinistro ocorrido tenha sido consequência do primeiro ou do segundo.

Tome-se como exemplo um roubo de carga por indivíduos fortemente armados a um veículo parado em um local não apropriado. A princípio existiria a "força maior"; porém, pode ser questionada a negligência daquele condutor ao ter - por vontade própria - estacionado o veículo em um local totalmente inseguro.

Portanto, visando evitar problemas nesse sentido, cada uma das partes deveria utilizar o tipo de seguro mais recomendável. Além do que, esses conflitos são extremamente desgastantes, raramente mantendo a boa relação comercial até então existente entre transportador e embarcador.

Se os transportadores que ainda não reviram sua forma de atuação na gerência de risco devem faze-lo, o mesmo se recomenda para os embarcadores. Esses também são afetados pelo roubo de cargas, mesmo quando indenizados pelos transportadores. Por isso, sua participação no gerência de risco também é fundamental. A identificação das mercadorias transportadas pode ser um importante procedimento adotado por esses indivíduos, o que permitiria o reconhecimento das cargas roubadas. Algumas iniciativas nesse sentido já começam a ser implantadas, porém ainda muito incipientemente. É o caso da identificação de medicamentos com códigos de barras, e até pelas mais recentes "raspadinhas".

Os corretoras/seguradores, diante do alto risco de roubo de cargas, passam a repensar a oferta dos seguros, causando os problemas já mencionados. Isso é perfeitamente compreensível, mesmo que muitas vezes seja condenado por alguns transportadores e embarcadores.

A presença do corretor de seguros é fundamental para a atividade, pois mais do que um simples agente comercial, esse deve prestar um serviço de assessoria referente à utilização de procedimentos de gerência de risco.

Além disso, os corretores/seguradores deveriam oferecer produtos adaptados (diferenciados) para os diversos "tipos" de transportadores, principalmente os de 
pequeno porte. Algumas corretoras - especializadas no ramo de transportes - já oferecem esses serviços - que, além de observarem um custo mais baixo, facilitam a operacionalização por parte dos transportadores; mesmo porque, como foi demonstrado, há muitas dificuldades encontradas por esses no que se refere à administração dos seguros de carga.

Nesse sentido, dever-se-ia ainda rever a regulamentação dos seguros de transporte, principalmente pelo fato da heterogeneidade do setor e da própria atividade de transporte rodoviário de carga. Um regulamentação rígida, tal como a existente - que inclusive fixa taxas de prêmios - pode prejudicar as negociações entre os demandantes dos seguros (transportadores e embarcadores) e os ofertantes (corretores/seguradores).

As exigências legais, que tornam compulsória a utilização de alguns seguros, também devem ser repensadas. As análises mostraram que tais exigências não têm sido necessariamente eficientes, mesmo que estejam por trás de uma maior frequência na utilização de alguns seguros. A própria teoria de gerência de risco prevê a opção pela retenção do risco, na qual o "não-seguro" está incluído. Portanto, as imposições legais atuam no sentido de eliminar essa opção dos transportadores e embarcadores.

A opção pela utilização dos seguros deve partir de uma vontade própria dos indivíduos e não de uma imposição legal. Algo que iria a esse encontro seria uma negociação mais clara entre, principalmente, transportadores e embarcadores, onde deveria ficar definida a importância e o comprometimento de cada parte no gerenciamento do risco na atividade.

Finalmente, o serviço de segurança pública é outra dimensão a ser considerada. Os problemas orçamentários do Estado culminam para uma má alocação de recursos no sentido de fornecer um serviço adequado de segurança, não só para a atividade, mas para a sociedade como um todo.

Acredita-se ser impossível a convivência com o risco do roubo de cargas sem uma atuação mais intensa do Estado. Isto é, mesmo que todas as partes envolvidas tomem as providências necessárias, a susceptibilidade ao risco continuará sendo um forte ponto de estrangulamento. 
Não apenas a segurança pública, mas também todas as outras faces de relacionamento do Estado com o problema devem ser considerados: aspectos tributários, jurídicos, penais, sanitários, estruturais, etc.

É fundamental ainda - e isso foi uma preocupação nesta pesquisa - não perder de vista a inserção do problema em um ambiente macro de profundas mudanças, as quais certamente acabam influenciando a contratação dos seguros.

$\mathrm{O}$ mercado segurador vive um período de transição, de uma economia fechada e pouco competitiva, para uma mais aberta e competitiva. A entrada de capital estrangeiro é um acontecimento que certamente deverá alterar o serviço, bem como exıgır uma revisão na sua regulamentação, revisão essa de importância indiscutível.

O setor de transporte rodoviário de carga, por sua vez, passa por transformações semelhantes no que se refere aos aspectos de competitividade. Todavia, enfrenta ainda um outro grande desafio: a mudança de concepção da unimodalidade - caracterizada historicamente por um predomínio sem igual na movimentação de cargas no País - para a multimodalidade, ou ainda, a operação logística, na qual, além da atuação de outras formas de transporte, também são contemplados servıços de informação, armazenamento, marketing, etc.

Enfim, o seguro de carga é um procedimento fundamental para o setor de transporte rodoviário, inclusive para o tratamento do risco de roubo, mesmo porque pode significar a "sobrevivência" das empresas em determinadas situações. Todavia, esse risco está adquirindo dimensões tais que o seguro pode não mais apresentar condições de cobri-lo, pois de um "evento incerto" pode passar para um "evento certo", ocasião na qual a premissa básica da teoria do seguro passaria a não mais estar presente. 


\section{REFERÊNCIAS BIBLIOGRÁFICAS}

ASFALTO à mão armada. Brasil Transportes, n.340, p.20-24, set. 1995.

ATTANASI, E.D.; KARLINGER, M.R. Risk Preferences and Flood Insurance. American Journal of Agricultural Economics, v.61, n.3, p.490-495, 1979.

BALLOU, R.H. Logística empresarial: transportes, administração de materiais e distribuição física/ Tradução Hugo T.Y. Yoshizaki. São Paulo: Atlas, 1993. 388p.

CASTRO, N. de Estrutura e desempenho do setor de transporte rodoviário de carga Pesquisa e Planejamento Econômico, v.18, n.1, p.55-82, abr. 1988.

CERNE, A.M. de M. O Seguro Privado no Brasil Rio de Janeiro: F. Alves, 1973. 236p.

CICCHETTI, C.J.; DUBIN, J.A. A Microeconometric Analysis of Risk Aversion and the

Decision to Self-Insurance. Journal of Political Economy, v.102, n.1, p.169-186, Feb. 1994.

CONJUNTURA ECONÔMICA. Especial: Mercado de Seguros, Capitalização e

Previdência Privada. Rio de Janeiro: Fundação Getúlio Vargas, mai. 1998.

COTTRIL, K. Internet becomes part of the fight. World Wide Shipping News, In: homepage: www.worldwideship.com, Sep. 1996.

CUNHA, A.B. da Mercado se seguros e inflação: o caso brasileiro. Revista Brasileira de Economia, v.49, n.1, jan/mar.1995. p.127-145.

EHRLICH, I.; BECKER, G.S. Market Insurance, Self-Insurance, and Self-Protection. Journal of Political Economy, v.80, n.4, p.623-648, Jul./Ago. 1972.

EVANS, W.N.; VISCUSI, W.K. Estimation of State-Dependente Utility Functions Using Survey Data. The Review of Economics and Estatistics, v.73, p.94-104, Feb. 1991.

FISCHER, H. El Seguro de Transportes de Mercancias. Zurich: Compañia Suiza de Reaseguros, s.d. 204p.

FRANÇA, R.L. (coord.) Enciclopédia Saraiva do Direito. São Paulo: Saraiva, 1977. 1 v. 
FRIEDMAN, B. Risk Aversion and the Consumer Choice of Health Insurance Option. The Review of Economics and Statistics, v.59, p.209-214, 1974.

FUNENSEG, Fundação Escola Nacional de Seguros. Seguros de Transportes Nacionais. Superintendência de Ensino, Asses.Téc. CARVALHO, M.A.G., Rev. e Atual. RIOMAYOR, A.J.G. Rio de Janeiro: FUNENSEG, 1994. 253p.

GALVÃO, O.J. de A. Desenvolvimento dos transportes e integração regional no Brasil uma perspectiva histórica. Planejamento e Políticas Públicas, v.3, p.183-213, jun. 1996.

GAMA, A.D. Código Penal Brasileiro: Dec. $\mathbf{N}^{\circ}$ 847, de 11 de outubro de 1890 . São Paulo: Saraiva Editores, 1923. 624p.

GIL, A.C. Como elaborar projetos de pesquisa. São Paulo: Atlas, 1987. 159p.

GOODE, W.J.; HATT, P.K. Métodos em Pesquisa Social. 2.ed. Trad. C.M.Bori São Paulo: Companhia Editora Nacional, 1968. 488p.

GREENE, W.H. Econometric analysis. 2ed. Englewood Cliffs, New Jersey: PrenticeHall, 1993. 789p.

GUJARATI, D.N. Basic Econometrics. 3.ed. New York: McGraw-Hill, 1995. 1v.

HOFFMANN, R. Estatística para Economistas 2.ed. São Paulo: Pioneira, 1991 426p.

HOFFMANN, R.; KAGEYAMA, A.A. Distribuição de Renda no Brasil, entre Famílias e entre Pessoas, em 1970 e 1980. Estudos Econômicos, v.16, n.1, p.25-51, jan./abr. 1986.

INDENIZAÇÕES consumıram US\$ 15 milhões, nos três prımeıros meses deste ano. Revista de Seguros, ano 76, n.812, p.8-12, abr./jun. 1995.

INFORME SIFRECA. Piracicaba: ESALQ-USP, maio 1997.

LOMBARDI, R. Informatização faz cair os roubos a banco. Estado de São Paulo. Cidades, São Paulo, 02 jul. 1998. p.C-1.

Manual Transportes São Paulo: Editora Manuais Técnicos de Seguros, 1994. 874p. 
MARQUIS, M.S.; HOLMER, M.R. Alternative Models of Choice Under Uncertanity and Demand for Health Insurance. The Review of Economics and Statistics, v.78, n.3, p.421-427, Aug. 1996.

MARTINS, P.R. Desmestificando o Contrato de Seguro. São Paulo: Federação das Empresas de Transporte de Cargas do Estado de São Paulo, 1993. 29p.

McFADDEN, D. Conditional Logit Analysis of Qualitative Choice Behavior. In: ZAREMBKA, P. (Ed.) Frontiers in Econometrics. New York: Academic Press, 1974. 252p.

MOONEY, J.E. The Perfect Crime for the 1990's: Cargo Theft Risk Management, v.41, p.59-61, Nov. 1994.

ORTÚZAR, J.de D.; WILLUMSEN, L.G. Modelling transport. 2.ed. West Sussex: John Wiley \& Sons, 1994, 439p.

Pesquisa anual do transporte rodoviário. Instituto Brasileiro de Geografia e Estatística. Rio de Janeiro. v.l (vários).

PINDYCK, R.S.; RUBINFELD, D.L. Econometrics Models and Economic Forecasts. 3.ed. New York: McGraw-Hill, 1991. 596p.

SElltiZ, WRIGHTSMAN, COOK Métodos de Pesquisa nas Relações Sociais. 4.ed. Trad. M.M.H. d'Oliveira e M.M. del Rey; Coord. J.R. Malufe e B.A. Gatti São Paulo: EPU, 1987. 133p.

SINDICATO DAS EMPRESAS DE TRANSPORTE DE CARGAS DE SÃO PAULO E REGIÃO (SETCESP) O Roubo de Cargas - Avaliação e Perspectivas. /Apresentado a 1. reunião do Conselho Nacional das Entidades Representativas do Transporte Rodoviário de Cargas (CONET), Canela RS, 1997/

TRIESCHMANN, J.S.; WIENING, E.A.; HEDGES, B.A.; TRUPIN, J.; FLITNER, A.L. Commercial Property Insurance and Risk Management 4.ed. Malvern: CPCU, 1994. v.2, p.97-128.

UELZE, R. Transporte \& Frotas São Paulo: Pioneira, 1977. 375p. 
VON NEUMANN, J.; MORGENSTERN, O Theory of Games and Economic Behavior. 3.ed. Princeton: University Press, 1953. 641p. 


\section{APÊNDICE}


UNIVERSIDADE DE SÃO PAULO

ESCOLA SUPERIOR DE AGRICULTURA "LUIZ DE QUEIROZ"

DEPART AMENTO DE ECONOMIA E SOCIOLOGIA RURAL CURSO DE PÓS-GRADUAÇÃO EM ECONOMIA APLICADA

Piracicaba, maio de 1998.

A/C: Sr(a). Antônio Cláudio Rafael

A C R Transp.

Prezado transportador:

A Universidade de São Paulo, através de seu curso de Pós-Graduação em Economia Aplicada da ESALQ, está desenvolvendo uma pesquisa no âmbito nacional com o objetivo de avaliar a eficiência do seguro de transporte rodoviário no Brasil, em vista de alguns problemas que vêm ocorrendo ultimamente, principalmente em relação ao roubo de cargas. Por esse motivo, estamos enviando o questionário em anexo para que seja respondido num prazo máximo de 15 dias.

Ressaltamos que os pesquisadores garantem absoluto sigilo em relação aos nomes das empresas e pessoas entrevistadas, sendo que, para isso, já enviamos um envelope devidamente endereçado e selado para facilitar a sua resposta, não exigindo a identificação da empresa.

Esperamos que os resultados desta pesquisa tenham uma siginificativa utilidade, principalmente como uma forma de ilustrar aquilo que o transportador de carga gostaria de ter disponível como serviço de seguro.

Lembramos ainda que o resultado desta pesquisa estará disponível àquelas empresas interessadas.

Qualquer informação à respeito desta pesquisa poderá ser obtida através do Coordenador do Curso de Pós-Graduação em Economia Aplicada Professor Dr. José Vicente Caixeta Filho, pelo telefone (019)4294119.

Antecipadamente agradecemos a sua colaboração,

AUGUSTO HAUBER GAMEIRO

Mestrando em Economia Aplicada

Endereço da Escola:

ESALQ/USP

Av. Pádua Dias, 11 - Caixa Postal 9

13418-900 Piracicaba SP 


\section{QUESTIONÁRIO (Favor responder todas as questoes)}
1) Este estabelecimento de transporte é: ( ) matriz da empresa
( ) filial da empresa

2) Quantas filiais tem a sua empresa?
3) Assinale a classificação de sua atividade:
( ) Empresa de Transporte de Carga de Terceiros
( ) Empresa que Transporta Carga Própria
( ) Transportador Autônomo

4) Assinale o tipo de carga mais transportada pela sua empresa:
( ) carga seca
( ) carga viva
( ) carga refrigerada
( ) Contêiner
( ) Bebidas
( ) granéis sólidos
( ) granéis líquidos
( ) automóveis
( ) Outras:

5) Sua empresa foi fundada há:
( ) menos de 5 anos
( ) entre 11 e 15 anos
( ) entre 21 e 25 anos
( ) entre 5 e 10 anos
( ) entre 16 e 20 anos
( ) mais de 25 anos

6) Qual o nú mero aproximado de camin hões de sua empresa (inclu indo agregados)?
( ) menos de 4
( ) entre 11 e 20
( ) entre 51 e 100
( ) entre 201 e 300
( ) entre 401 e 500
( ) entre 4 e 10
( ) entre 21 e 50
( ) entre 101 e 200
( ) entre 301 e 400
( ) mais de 500

7) Qual a idade média dos caminhões de sua empresa (incluindo agregados) ?
( ) menos de 2 anos
( ) entre 5 e 7 anos
( ) entre 11 e 13 anos
( ) entre 2 e 4 anos
( ) entre 8 e 10 anos
( ) mais de 13 anos

\section{8) Em relação à "saúde financeira" de sua atividade de transporte, no ano passado ela:}
( ) fechou "no vermelho"
( ) praticamente empatou os custos com as receitas
( ) obteve lucro líquido

9) Quantas vezes sua empresa já teve uma carga roubada nos últimos 5 anos?
( ) nenhuma vez
( ) 2 vezes
( ) 4 vezes
( ) entre 6 e 10 vezes
( ) entre 21 e 30 vezes
( ) 1 vez
( ) 3 vezes
( ) 5 vezes
( ) entre 11 e 20 vezes
( ) mais de 30 vezes

10) Enumere em ordem de importância, os procedimentos de gerência de risco adotados por sua empresa tratar o risco de roubo de cargas:
( ) fazer um seguro da carga
( ) fracionar a carga em volumes menores
( ) treinar motoristas para evitar o roubo de carga
( ) utilizar escolta para a frota
( ) equipar os veículos com rastreadores
( ) outro:
( ) não transportar cargas de valor elevado

11) Na sua empresa, quem é o responsável pela administração da carteira de seguro de carga?

( ) há um Departamento de Seguro ou pessoa exclusiva para executar essa tarefa

( ) não há uma pessoa que trabalhe exclusivamente com seguro

12) Como você classifica a administração da carteira de seguros de carga?
( ) Fácil e não burocrática
( ) Difícil, porém não burocrática
( ) Fácil, porém burocrática
( ) Difícil e burocrática

13) Que nota, de 0 a 10, você daria para a eficiência do Seguro de Carga RCTR-C (o Seguro de Responsabilidade Civil do Transportador Rodoviário de Carga, também chamado de seguro de tombamento)?

14) Que nota, de 0 a 10, você daria para a eficiência do Seguro de Carga RCF-DC (o Seguro de Responsabilidade Civil do Transportador Rodoviário por Desvio de Carga, também chamado de seguro de roubo)? 
15) Alguma vez uma corretora de seguro se negou a vender um seguro RCF-DC para sua empresa?
( ) não, nunca
( ) sim, pelo menos uma vez
( ) sim, várias vezes
( ) sim, sempre

16) O que você acha do preço do Seguro de carga RCTR-C?
( ) baixo
( ) ideal
( ) alto

17) $O$ que você acha do preço do Seguro de carga RCF-DC?
( ) baixo
( ) ideal
( ) alto

18) $O$ embarcador exige que sua empresa faça Seguro de carga RCTR-C?
( ) não exige
( ) exige algumas vezes
( ) sempre exige

19) O embarcador exige que sua empresa faça Seguro de carga RCF-DC?
( ) não exige
( ) exige algumas vezes
( ) sempre exige

20) Em relação ao Seguro $R R$, o seguro de Riscos Rodoviários, também chamado de "seguro do embarcador", responda:

( ) $\mathrm{O}$ embarcador exige que sua empresa faça esse seguro RR em nome do próprio embarcador;

( ) O embarcador faz este seguro RR quando entrega a carga para sua empresa transportar;

( ) O embarcador não exige, nem faz esse seguro;

( ) Não sabe responder a esta questão.

21) De uma maneira geral, sua empresa faz seguro de carga RTCR-C (averba a carga à seguradora):
( ) nunca faz o seguro RCTR-C
( ) em $60 \%$ dos fretes praticados
( ) em $20 \%$ dos fretes praticados
( ) em $80 \%$ dos fretes praticados
( ) em $40 \%$ dos fretes praticados
( ) em todos os fretes praticados

22) Caso a sua empresa não faça (não averbe) seguro de carga RTCR-C para todos os fretes, a partir de qual valor da carga, ela faz esse seguro:
( ) $\mathrm{R} \$ 2.000,00$
( ) $\mathrm{R} \$ 15.000,00$
( ) $\mathrm{R} \$ 50.000,00$
( ) $\mathrm{R} \$ 5.000,00$
( ) $\mathrm{R} \$ 20.000,00$
( ) $\mathrm{R} \$ 100.000,00$
( ) $\mathrm{R} \$ 10.000 .00$
( ) $R \$ 30.000,00$
( ) $\mathrm{R} \$ 200.000,00$

23) De uma maneira geral, sua empresa faz seguro de carga RCF-DC (averba a carga à seguradora):
( ) nunca faz o seguro RCF-DC
( ) em $60 \%$ dos fretes praticados
( ) em $20 \%$ dos fretes praticados
( ) em $80 \%$ dos fretes praticados
( ) em $40 \%$ dos fretes praticados
( ) em todos os frete praticados

24) Caso a sua empresa não faça (não averbe) seguro de carga RCF-DC para todos os fretes, a partir de qual valor da carga, ela faz esse seguro:
( ) $\mathrm{R} \$ 2.000,00$
( ) $\mathrm{R} \$ 15.000,00$
( ) $\mathrm{R} \$ 50.000,00$
( ) $\mathrm{R} \$ 5.000,00$
( ) $\mathrm{R} \$ 20.000,00$
( ) $\mathrm{R} \$ 100.000,00$
( ) $\mathrm{R} \$ 10.000 .00$
( ) $\mathrm{R} \$ 30.000 .00$
( ) $\mathrm{R} \$ 200.000 .00$

25) Qual o nome de sua corretora ou corretor de seguros de carga? avalia o serviço prestado por esta empresa?
( ) ruim
( ) razoável
( ) bom
( ) ótimo . Como você 